\title{
The Karpatian (late early Miocene) flora of the Mecsek area
}

\author{
LILLA HABLY \\ Botanical Department, Hungarian Natural History Museum, H-1431 Budapest, P.O. box 137, Hungary; \\ e-mail: hably.lilla@nhmus.hu \\ Received 9 September 2019; accepted for publication 28 January 2020 \\ In remembrance of the beautiful summers \\ spent collecting with my family in the Mecsek Mountains
}

\begin{abstract}
A rich macroflora has been collected from Karpatian (late early Miocene) layers of the Mecsek Mts during recent decades. The bulk of the fossil assemblage consists of leaves and also fruits of angiosperms. Among the more than a hundred taxa, several endemic species were described: Leguminocarpum mecsekense Andreánszky, Ailanthus mecsekensis Hably, Nyssa gyoergyi sp. nov., Nyssa gergoei sp. nov., Nyssa sp. 1, Clematis csabae sp. nov., Gordonia sp. and Carpolithes gergoei Hably et Erdei sp. nov. Many taxa were last recorded in the Carpathian Basin, e.g. Cedrelospermum, Ziziphus. Other taxa appeared in this flora, e.g. Quercus kubinyii, Podocarpium podocarpum, Liquidambar europaea and Populus populina, and later became dominant in the middle Miocene (Sarmatian) floras or even in the late Miocene (Pannonian) floras. Four main vegetation types were determined. The most significant types are subxerophytic vegetation showing high diversity, swamp vegetation, riparian vegetation, and a vegetation type growing in habitats with higher rainfall. Thermophilous flora elements are dominant in the assemblage, although "arctotertiary" species also appear. The floristic character of the flora supports the results of an earlier quantitative climate analysis of the Magyaregregy flora, according to which mean annual temperature was $15.6-16.6^{\circ} \mathrm{C}$ and coldest-month and warmest-month temperatures were $5-6.2^{\circ} \mathrm{C}$ and $24.7-27.9^{\circ} \mathrm{C}$, respectively. Generally the assemblage presented in this paper extends those climatological findings to the late early Miocene.
\end{abstract}

KEYWORDS: macroflora, late early Miocene, Karpatian, Mecsek Mts, Hungary

\section{INTRODUCTION}

Geological research in the Mecsek Mts dates back many decades. The extreme variability of its geology, high diversity of rock formations, and the potential scientific value of strata spanning geological ages have attracted many geologists and palaeontologists to this area.

It is beyond the scope of this work to cite all the relevant literature even in the field of Cenozoic research. Only some are mentioned here. Publications on the Cenozoic geology of the Mecsek Mts include Strausz (1926, 192628), Hámor (1964), Nagymarosy (1980, 1985), Chikán (1991), Szakmány and Józsa (1994), Magyar et al. (1999), Sebe (2009), Józsa et. al. (2009), Barabás (2010, 2011), Konrád and Sebe
(2010, 2011), Józsa and Szakmány (2011), Sebe et al. (2015a,b), Miklós (2018) and Kovács et al. (2018).

Palaeontological research on the Mecsek Mts has been very intensive, reflected in work published by Strausz (1950). Foraminifers and nannoplankton were studied by KoreczLaky (1968), and Báldi-Beke (1963) respectively. Palynological studies were carried out by Nagy (1969). The first floristic study of the Miocene flora of the Mecsek Mts was published by Staub (1882), who collected relatively few specimens from several sites and mentioned the localities Rákpatak-völgy near Ó-Falu, Nádasd, Hidas, Magyar-Hidas, Német-Hidas, 
Váralja, Puszta-Szobák, Komlóvölgy, Abaliget, Tekeres and Rákos, which all, except for Váralja, represent marl with fish scales. At Váralja, deposits preserving the plant remains were described as quartz-andesitic tuff. The figures, which are drawings of the fossil specimens, help in recognition of some genera and species: Pinus, Daphnogene (given as Cinnamomum by Staub), Ziziphus paradisiaca, Zelkova zelkovifolia (given as Planera Ungeri by Staub), Ailanthus confucii, Myrica and Leguminosae gen. et sp. (given as Cassia by Staub). The occurrence of these genera and species in the small fossil assemblage suggests that these taxa were frequent members of the Miocene flora of the Mecsek Mts. Unfortunately, many of the drawings could not be identified, and the often-invalid old names do not help in their taxonomic assignment.

Later, Andreánszky (1955) and Pálfalvy (1953, 1961, 1964, 1967) published data for the Miocene Mecsek flora, but they often merely gave lists of flora without providing figures and descriptions. That work did not constitute a survey of the Mecsek flora. Over a period of more than two decades, I and my colleagues have made collections, studied a number of taxa, and revised many of them (Hably, 1992b, 2001, 2002; Hably and Thiébaut, 2002). Collections made by Krisztina Sebe have yielded data essential to our knowledge of the Miocene flora of the Mecsek Mts. There are many sampling sites in the Mecsek Mts. Most of the fossil specimens $(\sim 90 \%)$ were collected in the surroundings of Magyaregregy, mostly from the so-called fish-scale marl there, but some also from volcanic deposits. Fossils have been preserved in the so-called fish-scale marl in Magyaregregy, Vágyom-völgy; Kisbattyán; Magyaregregy, Leánykôi-árok; Magyaregregy, Kisréti-árok; Magyaregregy, Farkasordítóárok; Abaliget, Kiskô-hegy; and also Abaliget, Nyáras-völgy. Fossils originated from rhyolitic tuff in Magyaregregy, Almás-patak; Kisbeszterce and Hetvehely, Kán. The late Miocene (Pannonian) flora of Mecsek is not discussed here; details can be found in Hably (2013), Hably and Sebe (2016) and Hably et al. (2019).

The main part of the monograph deals with systematics, describing and discussing more than 100 taxa. The Mecsek flora is extremely diverse. Beside the well-known common species, many rare taxa occur in the assemblage, and a high number of specimens could not be identified. To ground future research, the unidentified specimens are also discussed and figured. The extremely diverse assemblage is used to reconstruct the flora and vegetation, and to make a climatic analysis.

\section{GEOLOGICAL SETTINGS}

The area of Mecsek is situated in the SW Pannonian Basin on the Tisza-Dacia megaunit, a tectonic block south of the Mid-Hungarian Shear Zone. The Neogene stratigraphy of the eastern Mecsek area was summarized by Hámor (1970), whereas the western part was studied by Chikán (1991) and Barabás (2010). Widespread Lower Miocene fluvial clastics, including conglomerates to variegated clays (Szászvár Formation), are overlain by the Budafa Formation, traditionally regarded as of Karpatian (late Burdigalian) age (Gyalog, 1996; Gyalog and Budai, 2004; Budai et al., 2015) and consisting of three members: the Komló Claymarl Member, Pécsvárad Limestone Member, and the overlying Budafa Sandstone Member. The succession is overlain by the Badenian (Langhian), with normal marine Leitha limestones (Lajta Limestone Formation, Pécsszabolcs and Rákos Members) in the littoral zone, and offshore sands and silts (Tekeres and Szilágy Formations) in the basins, locally with coal-bearing swamp deposits (Hidas Formation) along the shores.

Most of the fossil plant remains were fossilized in the Komló Claymarl Member ("fishscale-bearing clay marl"). It is composed of dark grey, greenish grey, massive or laminated silty clay marl, calcareous silt and fine sands, with numerous fish scales and bones, and sometimes with tuff interbeds. K/Ar dating measurements from tuff interbeds within the Komló Claymarl showed an age of $16.82 \pm 0.65 \mathrm{Ma}$, i.e. Karpatian (late Burdigalian) (Sebe et al., 2019).

The absence of marine forms in the Pécsvárad Limestone and in most of the Komló Claymarl indicates a lack of connection to normal-salinity seas; thus these rocks are lacustrine deposits (Sebe et al., 2019). The lake sediments and the fauna suggest that instead of a system of smaller lakes, a contiguous waterbody called Lake Mecsek existed in the area. Karpatian to early Badenian age of the lake is indicated by K/Ar age and biostratigraphic dating of the overlying marine 
deposits described above (Sebe et al., 2019). The Pécsvárad and Komló Members are both interpreted as lake deposits and differ very much from the Budafa Sandstone Member; therefore, Sebe et al. (2019) united the two members as a separate formation, the Feked Formation. Consequently, the fish-scale-bearing clay marl sediments preserving the plant fossils belong to the Feked Formation, Komló Claymarl Member, dated as Karpatian (late Burdigalian) (Sebe et al., 2019).

\section{MATERIAL AND METHODS}

The fossil specimens are predominantly leaf impressions, but fruits and seeds, mainly winged ones, also frequently occur. Impressions are generally well preserved in the fish-scale marl owing to the finegrained sediment; however, cuticles are not preserved or are too poorly preserved for cuticular analysis. In some cases, twigs with some leaves or rarely with leaf and fruit remains are observed. A fossil flower is an exceptional remain, with the stamens, both the theca and filaments, having been fossilized, but no pollen is preserved. In addition to the plant fossils there are numerous fish scales (hence the name of the sediment), and insect fossils were also recovered.

The largest collection from the Miocene of the Mecsek, nearly 10000 specimens, is stored in the palaeobotanical collection of the Hungarian Natural History Museum, inventoried "HNHM-PBO". A smaller assemblage collected by Pálfalvy is stored in the collections of the Mining and Geological Survey of Hungary, inventoried "BK".

Fossil remains were studied using macromorphological methods. Descriptions follow Dilcher (1974) and Ellis et al. (2009). Observations by microscopy employed an Olympus SZX9 dissecting microscope and a Nikon Eclipse E600 microscope.

\section{SYSTEMATIC DESCRIPTIONS}

\author{
Pteridophyta \\ Eqisetopsida \\ Equisetaceae
}

\section{Equisetum parlatorii (Heer) Schimper}

Pl. 1, fig. 1

1855 Physagenia parlatorii Heer; Heer, p. 109, pl. 42, figs 2-17.

1959 Equisetum parlatorii (Heer) Schimper; Andreánszky, p. 44, pl. 7, figs 1-3, text-fig. 1.

Material. Magyaregregy: PBO 2017.82.1, 2018.225.1-2018.227.1.
Description. Stem fragment with nodes, $6.0 \mathrm{~cm}$ long, $0.5 \mathrm{~cm}$ wide. The stem jointed at the nodes. Four strong ridges on stem surface.

Discussion. Heer (1855) described numerous specimens from the Tertiary flora of Switzerland. Andreánszky (1959) published the species from the Sarmatian and Badenian floras of Hungary. There are several specimens in the Miocene flora of Veróce (Hungary; Hably in progress). It occurs in several European Tertiary floras as Equisetum sp. (Bohemian Massif; Akhmetiev et al., 2009).

\section{Pteridopsida \\ Polypodiales \\ Blechnaceae}

\section{Woodwardia muensteriana \\ (C. Presl in Sternberg) Kräusel \\ Pl. 1, fig. 2}

1838 Pecopteris münsteriana C. Presl; C. Presl in Sternberg, p. 145, pl. 36, fig. 2.

1866 Pteris bilinica Ettingshausen; Ettingshausen, p. 14, pl. 3, figs 14, 15 .

1881 Pteris bilinica Ettingshausen; Engelhardt, p. 77, pl. 1, fig. 1 (left).

1881 Woodwardia roessneriana Heer; Velenovský, p. 11, pl. 1, figs 1-8.

1921 Woodwardia muensteriana (C. Presl in Sternberg) Kräusel; Kräusel, p. 366, pl. 11, figs 2, $6-8$, pl. 12, fig. 4.

1971 Woodwardia muensteriana (C. Presl in Sternberg) Kräusel; Bůžek, p. 34, pl. 5, figs 16, 17, pl. 6, figs 1-4.

1985a Woodwardia muensteriana (C. Presl in Sternberg) Kräusel; Hably, p. 82, 136, pl. 2, figs 2-5.

2000 Woodwardia muensteriana (C. Presl in Sternberg) Kräusel; Sakala, p. 53, pl. 1, figs 1, 2.

Material. Magyaregregy, Vágyom-völgy: PBO 2017.45.1.

Description. Small apical fragment of pinnae. Pinna formed by conspicuous rachis with attached pinnulae, alternately arranged and mutually connected at base. Pinnulae $\sim 6 \mathrm{~mm}$ long and $2 \mathrm{~mm}$ wide, entire-margined, narrower at rounded apex. Secondary veins (main veins of pinnulae) entering from conspicuous main pinna vein. Tertiary veins running from both sides of secondaries toward, and ending at, pinnula margin.

Discussion. The species is well known in the European Tertiary floras, e.g. Pětipsy 
area, North Bohemian Basin, Czech Republic (Bůžek, 1971), Bilina Mine, Most Basin, Czech Republic (Sakala, 2000). From Hungary it was described from the Early Miocene flora of Ipolytarnóc (Hably, 1985a).

\section{Polypodiaceae gen. et sp. 1}

Pl. 1, fig. 5

Material. Kisbattyán: PBO 2012.168.1, Magyaregregy: PBO 2018.306.2.

Description. Two fragments of pinnae, one $2 \mathrm{~cm}$ long and $1.8 \mathrm{~cm}$ wide, the other $1.1 \mathrm{long}$ and $0.3 \mathrm{~cm}$ wide, shape of pinnae unclear. Veins forking.

Discussion. Venation details suggest an affinity with Polypodiaceae but no closer assignment is possible.

\section{Polypodiaceae gen. et sp. 2}

Pl. 1, fig. 3

Material. Magyaregregy: PBO 2006.741.2.

Description. Apical part of three pinnulae. Apex attenuate, venation forking. Veins end in apex.

Discussion. Small fragment, only venation suggests an affinity to Polypodiaceae.

Salviniaceae

\section{?Salvinia sp.}

Pl. 1, fig. 4

Material. Magyaregregy: PBO 2019.27.1.

Description. Leaf fragment $1.6 \mathrm{~cm}$ long, $0.6 \mathrm{~cm}$ wide, apical and basal parts of fragment acute. Margin entire. Strong reticulate venation.

Discussion. The strong reticulate venation is typical of this genus. However, the shape of the leaf fragment does not correspond to Salvinia reussii Ettingshausen or other wellknown species from the European Tertiary (Bůžek et al., 1992, 1996; Sakala, 2000; KovarEder et al., 2004). The occurrence of Salvinia confirms the presence of aquatic plants in the Miocene flora of the Mecsek Mts.

\section{Pinaceae}

Pinus sp. fascicles of two needles

Pl. 1, fig. 6

Material. Kisbattyán: PBO 2012.157.2, 2012.158.2, Magyaregregy, Vágyom-völgy: PBO 2004.135.2.

Des c r iption. Length of needles up to $6.2 \mathrm{~cm}$, width up to $0.1 \mathrm{~cm}$.

Discussion. Two specimens were found at Kisbattyán, both thinner and shorter than needles from Vágyom-völgy. Two- or three needle leaves of pines are common in the European Tertiary, often described as Pinus hepios (Unger) Heer or P. taedaeformis (Unger) Heer (Bůžek et al., 1996). In the Miocene flora of the Mecsek Mts they are a rare accessory element.

Pinus sp. fascicles of three needles

$$
\text { Pl. 1, fig. } 7
$$

Material. Magyaregregy: PBO 2002.621.2, Magyaregregy, Vágyom-völgy: 2004.133.2, 2004.134.2.

Description. Needle leaves in fascicles of three, length up to $15 \mathrm{~cm}$, original total length larger, width of needles up to $2 \mathrm{~mm}$.

Discussion. Three-needle foliage has been reported in the European Tertiary from several localities. From the late Oligocene (Egerian) of Hungary (Hably, 1990) it was mentioned as Pinus tuzsoni Novák. Records are also known in the Miocene flora of Parschlug (Kovar-Eder et al., 2004: pl. 1, figs 6, 8) and in the Cypris Shale (Czech Republic) described as Pinus rigios (Unger) Ettinshausen (Bůžek et al., 1996).

\section{Pinus sp. seed}

Pl. 2, figs 2, 3

Material. Kisbattyán: PBO 2012.159.2, Magyaregregy: PBO 2002.622.1, 2006.735.1, 2006.736.2, Magyaregregy-Leánykói-árok: PBO 2006.464.1, Magyaregregy, Farkasordító-árok: PBO cf. 2016.110.1, Magyaregregy, Vágyom-völgy: PBO 2004.132.1.

Description. Winged seeds, up to $3.8 \mathrm{~cm}$ long (usually $2 \mathrm{~cm}$ ) and $1 \mathrm{~cm}$ wide. Seeds frequently missing, shape ellipsoid-ovoid, diameter $0.3 \times 0.4(0.5) \mathrm{cm}$. Shape of wing elongated, 

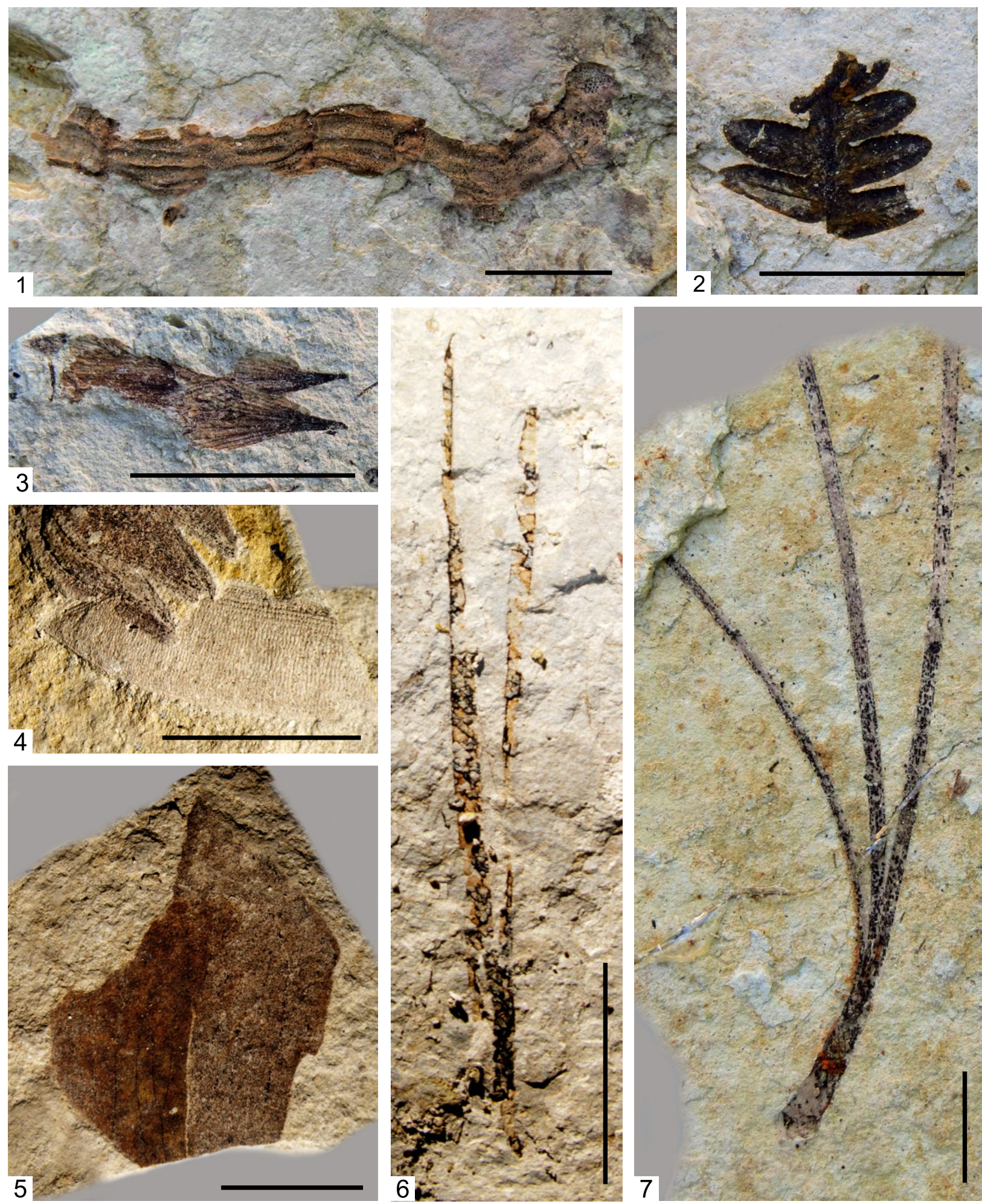

Plate 1. 1. Equisetum parlatorii (Heer) Schimper, stem, PBO 2017.82.1; 2. Woodwardia muensteriana (C. Presl in Sternb.) Kräusel, leaf fragment, PBO 2017.45.1; 3. Polypodiaceae gen. et sp. 2, leaf fragment, PBO 2006.741.2; 4. Salvinia sp., leaf fragment, PBO 2019.27.1; 5. Polypodiaceae gen. et sp. 1, leaf fragment, PBO 2012.168.1; 6. Pinus sp., two-needle leaf, PBO 2012.157.2; 7. Pinus sp., three-needle leaf, PBO 2004.133.2. Scale bar $=1 \mathrm{~cm}$

apical side of wing straight, basal side convex, apex obliquely cut.

Dis c u s sion. According to Bůžek et al. (1996), pine seeds are of two forms. The first is a relatively large seed surrounded by a broad wing.
The second type is smaller, with a narrower wing, and seems to be more abundant. Winged seeds of Pinus have been published from the European Miocene from the Cypris Shale (western Bohemia, Czech Republic; Bůžek et al., 1996), Parschlug (Austria; Kovar-Eder et al., 
2004) and the Upper Oligocene flora of Enspel (W Germany; Köhler and Uhl, 2014). These records are always of rare remains, never occurring en masse. In the Miocene flora of the Mecsek Mts their number is relatively high.

\section{Abies sp.}

Pl. 2, fig. 1

Material. Magyaregregy: PBO 2002.620.1.

Description. Winged seed, $2 \mathrm{~cm}$ long, $1.1 \mathrm{~cm}$ wide. Wing triangular, broadest near tip. Seed $0.7 \mathrm{~cm}$ long, $0.3 \mathrm{~cm}$ wide, broadest near apical part.

Discussion. Abies seeds are rare elements in the European Tertiary. For Hungary this is the first undoubted fossil record of the genus. In the large collection only one specimen was found, which may indicate that Abies trees were located far from the depositional basin. Among modern members of the genus, Abies nordmanniana (Steven) Spach originated from the Caucasus and is distributed on the eastern and southern Black Sea coast, in Turkey, Georgia, the Russian Caucasus, northern Armenia and northwestern Azerbaijan. It occurs at 900-2200 m a.s.l. in mountainous areas with rainfall over $1000 \mathrm{~mm}$. During the Miocene a probably similar environment existed near the Mecsek Mts.

\section{Cupressaceae}

\section{Glyptostrobus europaeus (Brongniart) Unger \\ Pl. 2, figs $4,6-8$}

1833 Taxodites europaeum Brongniart; Brongniart, p. 168.

1850b Glyptostrobus europaeus (Brongniart) Unger; Unger, p. 434.

1988 Glyptostrobus europaeus (Brongniart) Unger; Kovar-Eder, p. 28, pl. 1, figs 4-7.

1992c Glyptostrobus europaeus (Brongniart) Unger; Hably, p. 8, p. 24, pl. 1, fig. 3 .

1996 Glyptostrobus europaeus (Brongniart) Unger; Hably and Kovar-Eder, p. 71, pl. 2, figs 2-4, 6 .

2004 Glyptostrobus europaeus (Brongniart) Unger; Kovar-Eder et. al., p. 54, pl. 1, figs 14-16.

2009 Glyptostrobus europaeus (Brongniart) Unger; Erdei et al., p. 75, pl. 4, figs 3-7, pl. 5, figs 1-9.

2011 Glyptostrobus europaeus (Brongniart) Unger; Erdei and Magyari, p. 140. text-figs 2-5.

2013 Glyptostrobus europaeus (Brongniart) Unger; Hably, p. 42, pl. 3, figs 6, 7, pl. 4. figs 1, 2.
Material. Abaliget, Kiskó-hegy: PBO 2017.31.3, Magyaregregy: PBO 2000.204.1, 2000.283.1, 2000.323.2-2000.357.1, 2000.417.2$2000.418 .2,2000.449 .2,2000.450 .1,2000.456 .2-$ 2000.459.2, 2000.485.2, 2000.486.2, 2002.646.2, 2003.251.1, 2006.576.1, 2006.733.2, 2006.751.2, 2007.14.1, 2007.54.2-2007.56.2, 2013.196.2, 2017.68.1-2017.70.1, 2017.143.1, 2018.253.2, 2019.17.2, 2019.49.2, 2019.88.1, 2019.95.1, Magyaregregy, Farkasordító-árok: PBO 2006.494.1, 2006.495.1 (with cone), 2016.126.1, Magyaregregy, Leánykôi-árok: PBO 2006.468.1, 2016.84.12016.85.1, Magyaregregy, Vágyom-völgy: PBO 2017.153.1 (seed), 2017.154.1, 2019.39.2.

Description. Twigs up to $14 \mathrm{~cm}$ long. Leaves scale-like, helically arranged, cupressoid type, at most $5 \mathrm{~mm}$ long and $1 \mathrm{~mm}$ wide. Cones rounded, up to $1.1 \mathrm{~cm}$ diam. Cone scales barely visible.

Discussion. Glyptostrobus europaeus is an accessory element in the flora of Magyaregregy. It occurs exclusively in fish-scale marl in the Miocene of the Mecsek Mts. No records are known from volcanic sediments. Cones are very rare; only four cone specimens appeared from Farkasordító-árok. All other records are twigs. The leaves are very small, much smaller than specimens from the late Miocene floras of Hungary (Hably, 2013). The morphology of cones from Magyaregregy considerably differs from those reported in the late Miocene floras of Hungary. The cones from Magyaregregy are much smaller and more rounded than the cones from the Pannonian (late Miocene), which may be as much as $3 \mathrm{~cm}$ long and $1.5 \mathrm{~cm}$ wide. The shape of the cones from the Pannonian is also different: not rounded, but obovate.

\section{Tetraclinis salicornioides \\ (Unger) Kvaček}

$$
\text { Pl. 2, fig. } 5
$$

1847 Thuytes salicornioides Unger; Unger, p. 11, pl. 2, figs 1-4.

1976 Callitrites brongniartii Endlicher; Bůžek et al., p. 83, pl. 2, figs 5-7, text-fig. 2.

1988 Tetraclinis salicornioides (Unger) Kvaček; Kvaček, p. 48, pl. 2, figs 3, 10.

1995 Tetraclinis salicornioides (Unger) Kvaček; Kvaček and Walther, p. 39, pl. 1, fig. 5.

2014 Tetraclinis salicornioides (Unger) Kvaček; Köhler and Uhl, p. 8, pl. 2, fig. 2.

Material. Magyaregregy: PBO 2017.72.1. 

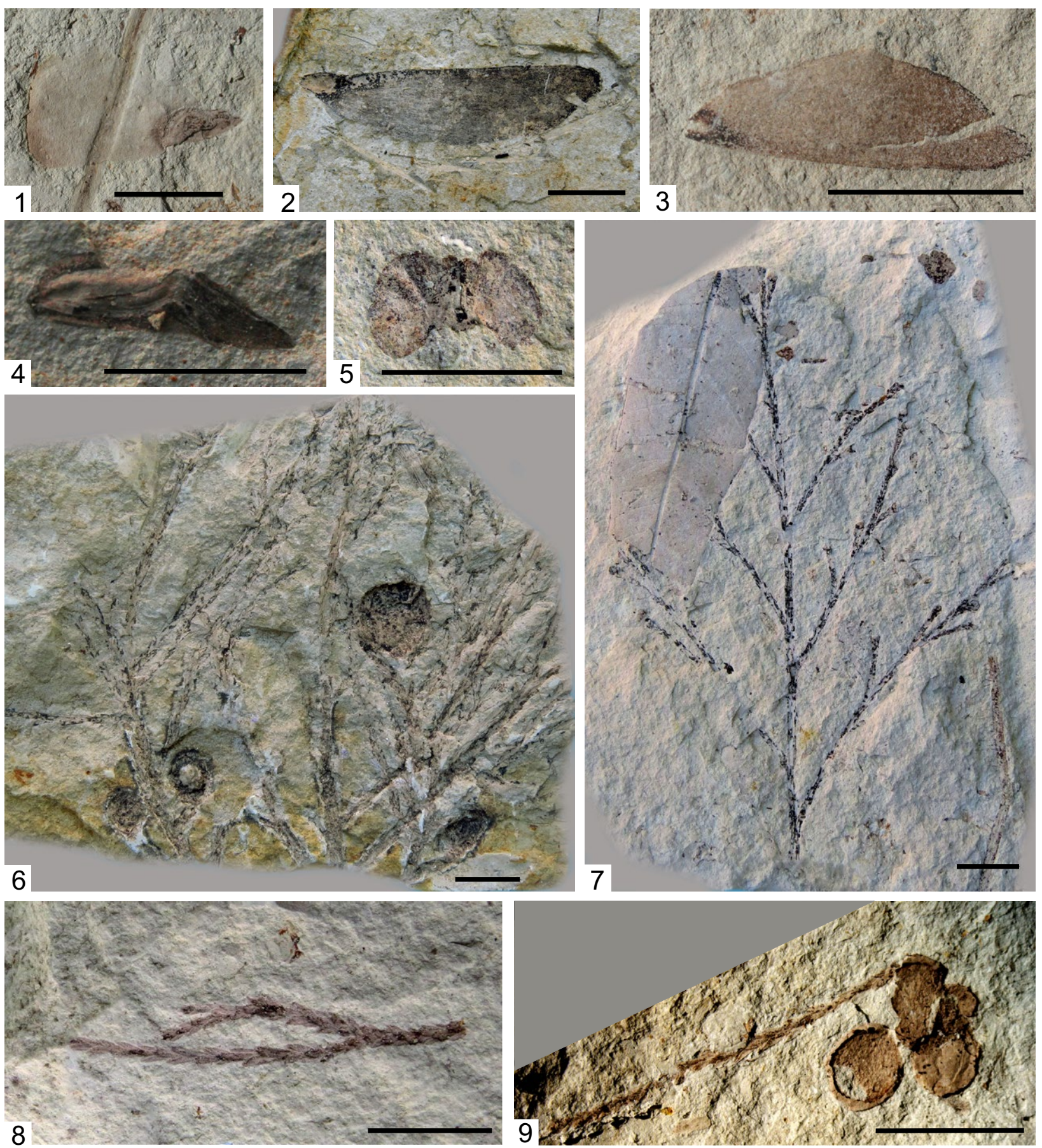

Plate 2. 1. Abies sp., seed, PBO 2002.620.1; 2. Pinus sp. seed, PBO 2004.132.1; 3. Pinus sp., seed, PBO 2002.622.2; 4. Glyptostrobus europaeus (Brongniart) Unger, seed, PBO 2017.153.1; 5. Tetraclinis salicornioides (Unger) Kvaček, seed, PBO 2017.72.1; 6. Glyptostrobus europaeus (Brongniart) Unger, twigs with cones, PBO 2006.495.1; 7. Glyptostrobus europaeus (Brongniart) Unger, twigs, PBO 2003.251.1; 8. Glyptostrobus europaeus (Brongniart) Unger; twigs, PBO 2000.330.1; 9. Cupressaceae gen. et sp., twig with cones, PBO 2018.313.1. Scale bar $=1 \mathrm{~cm}$

Description. Seed with two equal membranaceous wings, symmetrical, broadly ovate, wings $0.55 \mathrm{~cm}$ long, $0.3 \mathrm{~cm}$ wide, $0.9 \mathrm{~cm}$ span.

Discussion. This is the first seed record from the Miocene flora of the Mecsek Mts. T. salicornioides was a frequent accessory element of Tertiary subtropical to warm-temperate humid forest vegetation. It was very frequent in the younger mastixioid floras of Central Europe as a component of the Notophyllous Broad-leaved Evergreen or Mixed Mesophytic Forest formations (Kvaček, 1989). Generally, leaf whorls occurred in some Tertiary floras of Hungary from the early Oligocene up to the late Miocene. It was frequent in the early Oligocene flora of the Tard Clay Formation (Hably, 1979) as well as in the early Miocene flora of Ipolytarnóc 
(Hably, 1985a). In the late Miocene of the Mecsek Mts its leaf whorls were also reported from the termophilous flora of Pécs-Danitzpuszta (Hably and Sebe, 2016). From Bohemia it was recorded from the Oligocene flora of Markvartice (Bůžek et al., 1976) and Suletice (Kvaček and Walther, 1995). From the North American Oligocene and Miocene a whole cone as well as seeds were described as T. salicornioides var. praedecurrens (Knowlton) Kvaček, Manchester, Schorn (Kvaček et al., 2000).

\section{Cupressaceae gen. et sp.}

$$
\text { Pl. 2, fig. } 9
$$

Material (cones). Magyaregregy: PBO 2018.311.2-2018.314.2, 2018.316.1-2018.319.1, 2018.321.1, 2019.83.2.

Material (twigs). Magyaregregy: PBO 2018.313.2, 2018.315.1, 2019.86.2.

Description. Maximum diameter of cones $1.1 \mathrm{~cm}$ but generally $0.5-0.6 \mathrm{~cm}$, shape of cones rounded or rounded elongate. Surface of cones not smooth, cone scales not observable. Four cones in one group attached to twig. Leaves on twig maximum $0.2 \mathrm{~cm}$ long, scale-like, cupressoid type. Apex of leaves acute, leaves appressed to twig. Leaves arranged spirally in decussate pairs.

Discussion. These small cones presumably are unripe. Many twig remains of the cupressaceous Glyptostrobus europaeus were collected in Magyaregregy but these are the only cone remains. They are much smaller than other Glyptostrobus cones from the late Miocene (Hably, 2013). They may be unripe cones of Glyptostrobus but no morphological character is preserved to support this affinity.

\section{Magnoliaceae}

\section{cf. Magnolia sp.}

$$
\text { Pl. 3, fig. } 1
$$

Material. Kisbattyán: PBO cf. 2012.151.2cf. 2012.153.2, Magyaregregy, Almás-patak: PBO cf. 2006.541.1, Magyaregregy, Farkasordító-árok: PBO cf. 2006.492.1, Magyaregregy, Vágyom-völgy: PBO 2007.235.3, 2017.152.2.

Description. Simple leaves, lamina shape ovate to oblanceolate. Original length of lamina up to $15 \mathrm{~cm}$ (fossil fragment $10 \mathrm{~cm}$ ), width
$3.7 \mathrm{~cm}$. Apex acute or missing, base missing. Margin entire, venation camptodromous, brochidodromous. Midvein strong and straight, secondaries strong, running from midvein in acute angle, joining near margin and forming loops. Between secondaries, relatively strong and dense tertiary venation perpendicular to secondaries.

Discussion. Without cuticular analysis it is difficult to identify Magnolia, but the character of the coriaceous leaves and the venation type suggest that these leaves probably belong to this genus.

\section{Lauraceae}

\section{Daphnogene cinnamomifolia}

(Brongniart) Unger forma lanceolata sensu Kvaček and Walther

Pl. 3, figs 2-6

1850a Daphnogene lanceolata Unger; Unger, p. 424.

1950 Cinnamomophyllum scheuchzeri (Heer) Kräusel et Weyland; Kräusel and Weyland, p. 68, pl. 11, fig. 7, pl. 6, figs 1-6, pl. 17, fig. l, textfig. 25.

1978 Daphnogene lanceolata Unger; Mai and Walther, p. 40, pl. 2, fig. 1-23, pl. 19, figs 1-15, pl. 20, figs l-4.

1990 cf. Daphnogene lanceolata Unger; Hably, p. 11, text-figs 3, 15, 17, 29, 35, 38.

1994 cf. Daphnogene lanceolata Unger; Hably, p. 11, pl. 2, figs 5, 6, pl. 3, fig. 4, text-figs 10, 15, $18,19$.

1995 Daphnogene cinnamomifolia (Brongniart) Unger forma lanceolata; Kvaček and Walther, p. 32, text-fig. $4 / 10$.

Material. Abaliget, Kiskó-hegy: PBO 2017.28.2, 2017.30.1, 2017.31.3, Abaliget, Nyáras-völgy: PBO 2016.29.1, 2016.32.1, Kisbeszterce: PBO 2012.115.1 = counterpart 2012.122.1, 2012.123.2, Magyaregregy: PBO 99.531.1-99.549.1, 99.551.1-99.618.2, 2000.216.2-2000.258.2, 2000.275.3, 2000.388.1, 2000.389.1, 2000.430.1-2000.436.1, 2000.466.22000.477.2, 2001.752.1, 2001.753.1, 2001.923.22001.925.1, 2002.476.2-2002.485.2, 2002.540.2, 2002.759.4-2002.761.2, 2002.979.2, 2006.449.1, 2006.450.1, 2006.513.1, 2006.530.1-2006.537.1, 2006.562.1, 2006.575.1-2006.577.2, 2006.739.2, 2006.745.2-2006.747.2, 2007.10.1, 2007.11.1, 2007.65.2-2007.74.1, 2007.115.2, 2007.125.1, 2013.193.2, 2016.141.1, 2017.118.2, 2018.252.2, 2018.269.2, 2018.270.2, 2018.272.2, 2019.84.1, Magyaregregy, Almás-patak: PBO 2006.530.1- 

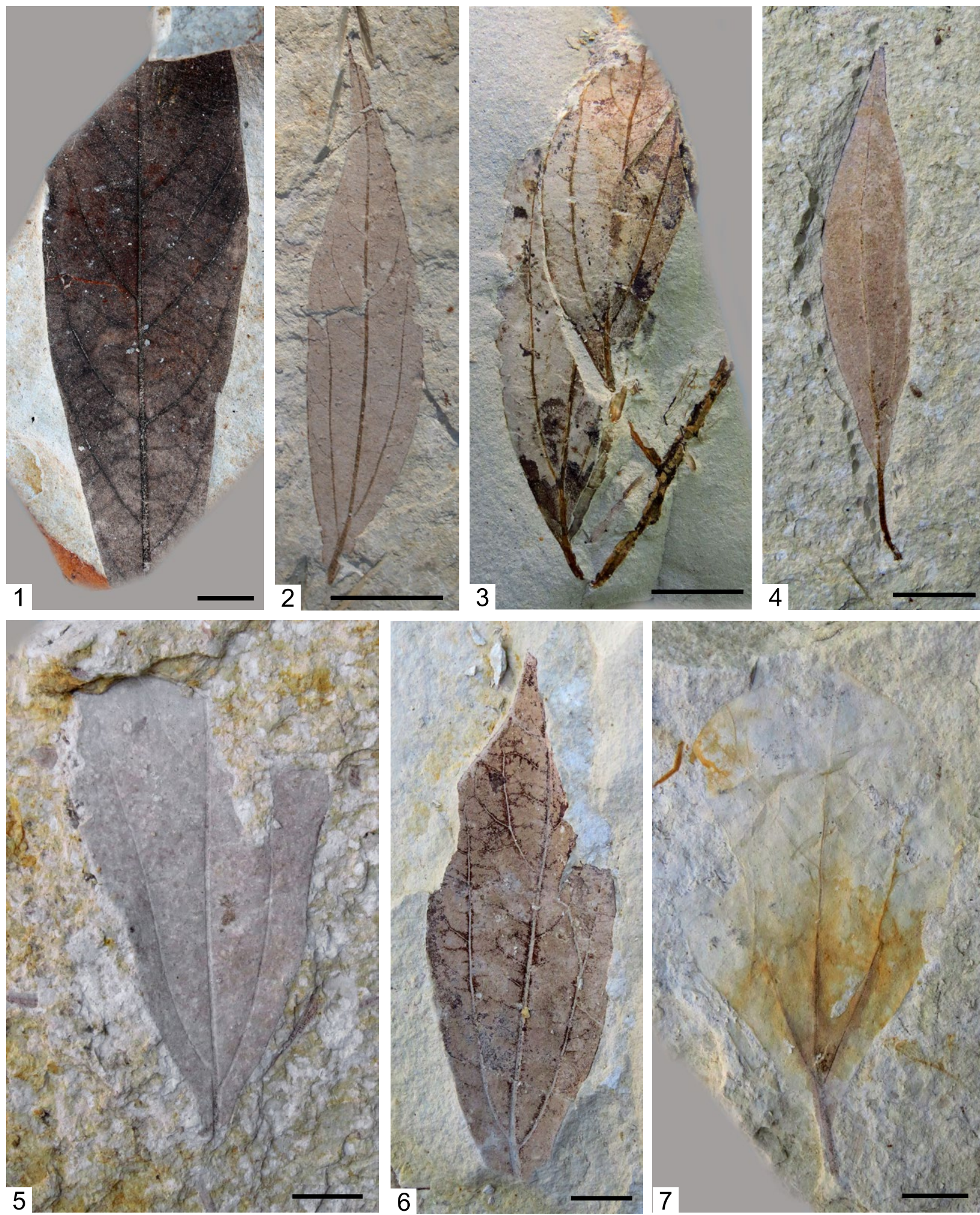

Plate 3. 1. cf. Magnolia sp., leaf, PBO 2017.152.2; 2-7. Daphnogene cinnamomifolia (Brongniart) Unger forma lanceolata, Kvaček and Walther, 2. PBO 99.549.2, 3. PBO 2017.52.2, 4. PBO 99.590.1, 5. PBO 2006.577.2, 6. PBO 2000.243.2, 7. PBO 99.550.2. Scale bar $=1 \mathrm{~cm}$

2006.537.1. Magyaregregy, Farkasordító-árok: PBO 2016.127.1, 2016.128.1, Magyaregregy, Leánykôi-árok: PBO 2016.91.1-2016.93.1, 2016.96.1, Magyaregregy, Vágyom-völgy: 2002.355.1-2002.358.1, 2002.367.1-2002.368.1, 2004.118.2-2004.122.2, 2007.222.1, 2017.52.2.
Description. Simple leaves, petiole frequently preserved, petiole up to $1.2 \mathrm{~cm}$ long. Shape of lamina lanceolate, lamina length up to $8.7 \mathrm{~cm}$, width up to $3.0 \mathrm{~cm}$. Margin entire, base and apex acute, midvein strong. Venation brochidodromous, two imperfect suprabasal veins. 
Secondaries depart from midvein at apical part of lamina and form loops. Dense tertiary venation runs almost perpendicular to midvein. Several small veins depart from basal veins toward margin and form loops with each other.

Discussion. D. cinnamomifolia is the most frequent Daphnogene species in the Oligocene and early-middle Miocene of Hungary. Kvaček and Walther (1995) distinguished two forms of this species. The narrower one is forma lanceolata, which is the most frequent form of this species in Hungary.

\section{Daphnogene cinnamomifolia}

(Brongniart) Unger forma cinnamomifolia sensu Kvaček and Walther

Pl. 3, fig. 7, pl. 4, figs 1,2

Material. Abaliget, Nyáras-völgy: PBO 2016.28.1, Magyaregregy: PBO 99.550.2, Magyaregregy, Leánykói-árok: PBO 2016.94.1, 2016.95.1, 2016.98.1, Magyaregregy, Farkasordító-árok: PBO 2015.680.1, 2016.126.1.

Description. Simple leaves without petiole. Shape of lamina ovate to narrow ovate, length up to $6 \mathrm{~cm}$, width up to $3.3 \mathrm{~cm}$. Base and apex acute, margin entire, venation camptodromous, brochidodromous. Midvein and basal veins strong, basal veins subrabasal, imperfect.

Discussion. This form is described as the shade leaf of Daphnogene cinnamomifolia (Kvaček and Walther, 1974, 1995); it is often accompanied by forma lanceolata. Morphologically, leaves of $D$. cinnamomifolia forma cinnamomifolia differ from forma lanceolata in the shape of lamina: the latter is narrower. It is a frequent element of wetland vegetation, e.g. Vértesszólós (Hably, 1990).

\section{Daphnogene cinnamomifolia (Brongniart) Unger}

Material. Magyaregregy: PBO 2016.130.2, 2016.141.1, 2017.7.2-2017.9.2, 2017.63.1, 2017.64.1, 2019.4.1, 2019.15.1, 2019.22.3, 2019.75.1, Magyaregregy, Leánykối-árok: PBO 2016.97.1, 2016.99.1.

Description. Leaf fragments with characteristic strong basal veins and entire margin.

Dis c u s sion. The specimens belong to this species based on their characteristic morphology.

\section{Daphnogene sp.}

Material. Abaliget, Nyáras-völgy: PBO 2016.33.1, 2016.156.1, Magyaregregy: PBO 2002.759.4-2002.761, 2016.296.2, 2017.119.2, 2017.127.2, 2018.271.1, 2019.18.2, 2019.87.1, Magyaregregy, Vágyom-völgy: PBO 2017.47.2.

Description. Leaf fragments, generally basal part of lamina preserved, showing characteristic strong basal veins and entire margin.

Discussion. These fragments probably also belong to $D$. cinnamomifolia, but their fragmentary preservation prevents identification beyond generic level.

\section{Laurophyllum markvarticense Kvaček}

$$
\text { Pl. 4, figs 3-5 }
$$

1971 Laurophyllum markvarticense Kvaček; Kvaček, p. 52 , pl. 6 , figs $1-3$, text-fig. 2 .

1996 Laurophyllum markvarticense Kvaček; Bůžek et al., p 26, pl. 17, fig. 4, pl. 19, fig. 6 .

1999 Laurophyllum markvarticense Kvaček; Meller et al., p. 131, pl. 2, figs 1, 2.

Material. Abaliget, Nyáras-völgy: PBO 2016.38.2.

Description. Leaf fragment, length $1.4 \mathrm{~cm}$. On adaxial cuticle, ordinary epidermal cells polygonal, cells of various size, anticlinal walls straight. On abaxial cuticle, paracytic stomata. Guard cells narrow, stomatal slit very narrow. Subsidiary cells large, shape angular.

Discussion. Macromorphological traits of the leaf fragment are not preserved. Cuticular details were preserved, enabling the use of microscopy to help identify the species. It was described from the late Oligocene of the Czech Republic (Kvaček, 1971) and was reported also from the Miocene. Its occurrence indicates warm subtropical climate. It was an evergreen element of laurel forests.

\section{Laurophyllum sp.}

Pl. 4, fig. 6,7

Material. Kisbattyán: PBO cf. 2012.140.1 -2012.150.1, Kisbeszterce: PBO 2012.131.2, 2012.138.1, 2012.139.2, 2019.3.1, Magyaregregy: PBO 2000.492.1, 2001.762.1, 2001.938.1, 2006.749.2, 2006.750.1, 2006.776.1, 2007.24.2, 2007.33.2, 2007.58.2-2007.63.1, 2007.64.2, 2007.85.2, 2007.115.2, 2016.290.2, 2016.291.2, 2017.78.2, 2017.80.1, 2017.102.1, 2017.110.1, 

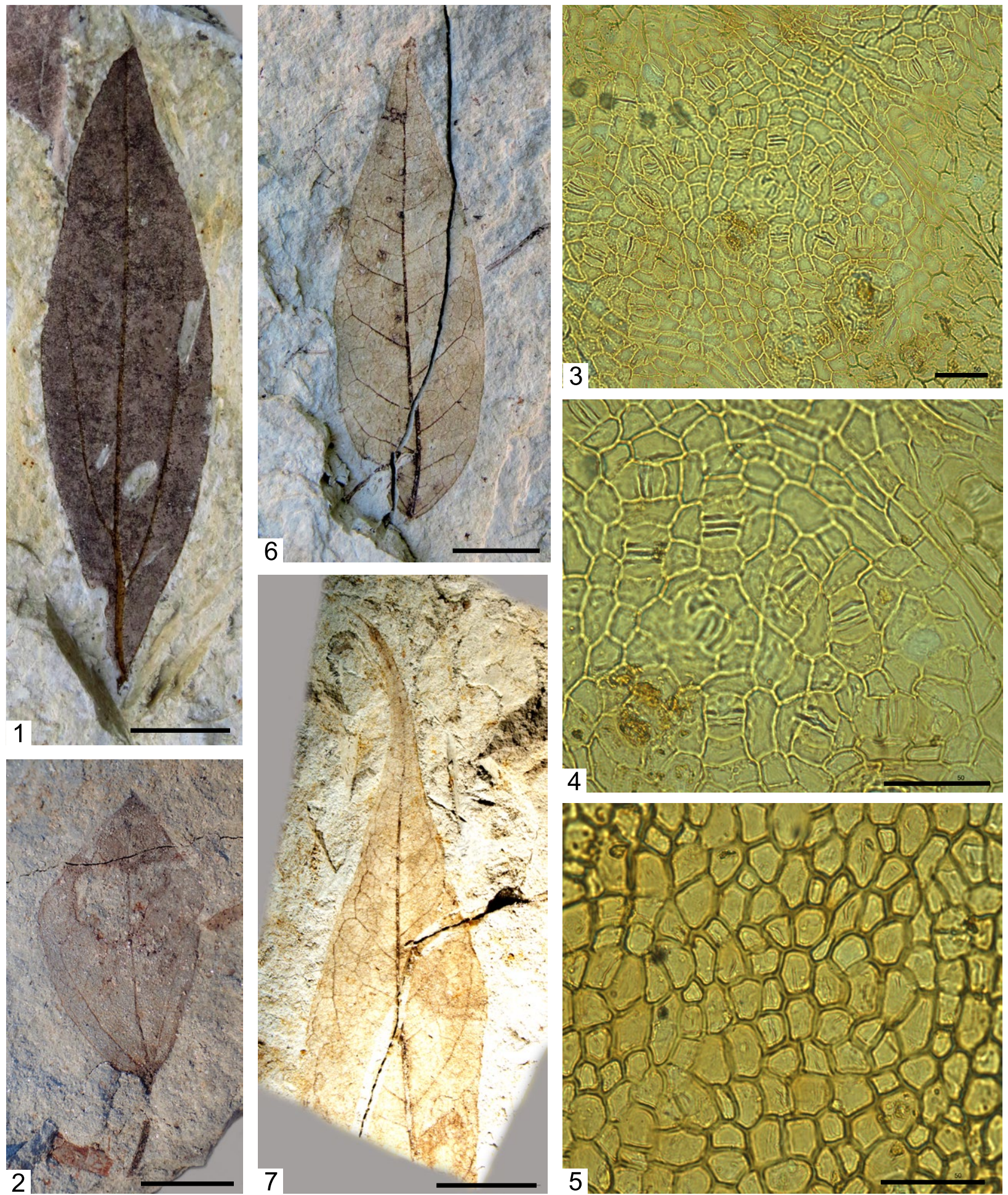

Plate 4. 1, 2. Daphnogene cinnamomifolia (Brongniart) Unger forma cinnamomifolia Kvaček et Walther, 1. PBO 99.559.2, 2. PBO 2016.28.1; 3-5. Laurophyllum markvarticense Kvaček, 3. lower cuticle, PBO 2016.38.2, 4. lower cuticle, PBO 2016.38.2, 5. upper cuticle, PBO 2016.38.2; 6, 7. Laurophyllum sp., leaf, 6. PBO 2017.102.1, 7. PBO 2004.129.2. Scale bar $=1 \mathrm{~cm}$

2017.139.2, 2018.239.1,2018.246.2,2018.273.22018.283.1, 2018.294.2, Magyaregregy, Almás-patak: PBO cf. 2006.525.1-2006.528.1, 2006.546.1, 2006.548.1, Magyaregregy, Vágyomvölgy: PBO 2004.129.2, 2017.150.2.

Description. Simple, entire-margined leaves of various size. Apex acute to very long attenuate, as a drip tip, base acute. Venation camptodromous, brochidodromous; major secondaries festooned brochidodromous with accessory loops of higher gauge.

Discussion. Without cuticle it is difficult to identify Laurophyllum leaves to species level, but the entire margin and the character of the 
leaf venation suggest that they belong to this form genus.

\section{Laurocarpum sp.}

Pl. 5, figs 1, 2

1856 Cinnamomum polymorphum Heer partim; Heer, p. 88 , pl. 94, figs $12-17$.

1995 Laurocarpum; Kvaček and Walther, p. 35, pl. 2, figs 6,8 .

2000 Laurocarpum; Sakala, p. 56, pl. 3, fig. 5.

Material. Magyaregregy: PBO 2018.262.12018.264.2, 2018.259.2, Magyaregregy, Vágyom-völgy: PBO 2018.265.2.

Description. Drupes with stalks, stalks shorter or longer. Drupes $0.5-0.7 \mathrm{~cm}$ long, 0.4-0.5 cm wide, roundish, narrowing towards apex. In the most complete specimen, stalk $7 \mathrm{~cm}$ long, branching three times, bearing six drupes. Side branches in some cases bifurcate at the end of stalks with drupes.

Discussion. Generally, single drupes were found, only one specimen having a longer (7 cm long) stalk bearing 6 drupes. The form genus Laurocarpum was described by E. Reid and M. Chandler from the London Clay (Reid and Chandler, 1933); it rarely occurred or was described from localities of the European Tertiary. Recently it was mentioned from the Oligocene and early Miocene of the Czech Republic (Kvaček and Walther, 1995; Sakala, 2000). In the Miocene flora of the Mecsek Mts there are numerous leaf remains belonging to the family Lauraceae, which corroborates the occurrence of the fruit.

Polygonaceae gen. et sp.

$$
\text { Pl. 5, fig. } 3
$$

Material. Magyaregregy: PBO 2019.57.3.

Description. Simple petiolate leaf, petiole strong, $1 \mathrm{~cm}$ long. Lamina wide ovate, $4.1 \mathrm{~cm}$ long, $3.8 \mathrm{~cm}$ wide. Base asymmetrical, auriculate, apex acute. Midvein strong, major secondaries brochidodromous, minor secondaries running out from major secondaries and forming loops between major secondaries and margin. Margin entire.

Discus sion. Leaves of the extant Antigonon leptopus Hook et Arn. of the Polygonaceae family show morphological similarity to the fossil leaf. Leaves of other arboreal plants displaying a similar shape of lamina have venation different from the fossil leaf. The auriculate base of the leaf is a trait not observed in most genera frequently occurring in the fossil material. The species Antigonon leptopus is a liana occupying habitats in wetland habitats both in tropical/subtropical and in warm-temperate regions. A single specimen was recovered from the Mecsek flora. This may mean that the plant was very rare or occurred in habitats far from the depositional basin.

\section{Berberidaceae}

\section{Berberis andreanszkyi Kvaček et Erdei}

$$
\text { Pl. 5, fig. } 4
$$

1955 Lomatites aquensis Saporta; Cziffery-Szilágyi, p. 25 , pl. 5 , fig. $15^{\mathrm{a}}$.

1966 Lomatites aquensis Saporta; Andreánszky, p.36, text-fig. 21.

2001 Berberis andreanszkyi Kvaček et Erdei; Kvaček and Erdei, p. 2, fig. 1a-f.

Material. Magyaregregy: PBO 2018.293.1, Magyaregregy, Vágyom-völgy: PBO 2017.145.2.

Description. Simple leaves with very short petiole $(0.2 \mathrm{~cm}$ long). Shape of lamina linear oblong, slightly curved, length of lamina $7.2 \mathrm{~cm}$ (original length $\sim 7.7 \mathrm{~cm}$ ), width 0.5 to $0.9 \mathrm{~cm}$. Apex missing, base cuneate. Only midvein visible, other veins not observable. Margin toothed along upper third of lamina, otherwise entire. Teeth small, arranged more frequently close to apex. Tooth apex spinose.

Discussion. This species was described from the Hungarian Tertiary (Kvaček and Erdei, 2001). A few specimens were found in the Sarmatian (Middle Miocene) flora of Erdóbénye as well as the Egerian (Upper Oligocene) flora of Wind-bricky. In Magyaregregy only one specimen was documented; it is similar to another species, Berberis kymeana (Saporta) Kvaček et Erdei, described from the Miocene floras of Kymi (Greece) and Aix-en-Provence (Kvaček and Erdei, 2001). In all localities the species seems to be a rare accessory element. The plant associations in floras having $B$. andreanszkyi or $B$. kymeana are similar in many cases to the flora of Magyaregregy, sharing many elements.

\section{Mahonia sp.}

Pl. 5, figs 5,6

Material. Magyaregregy: PBO 2016.293.2, 2017.104.1, 2017.105.2. 

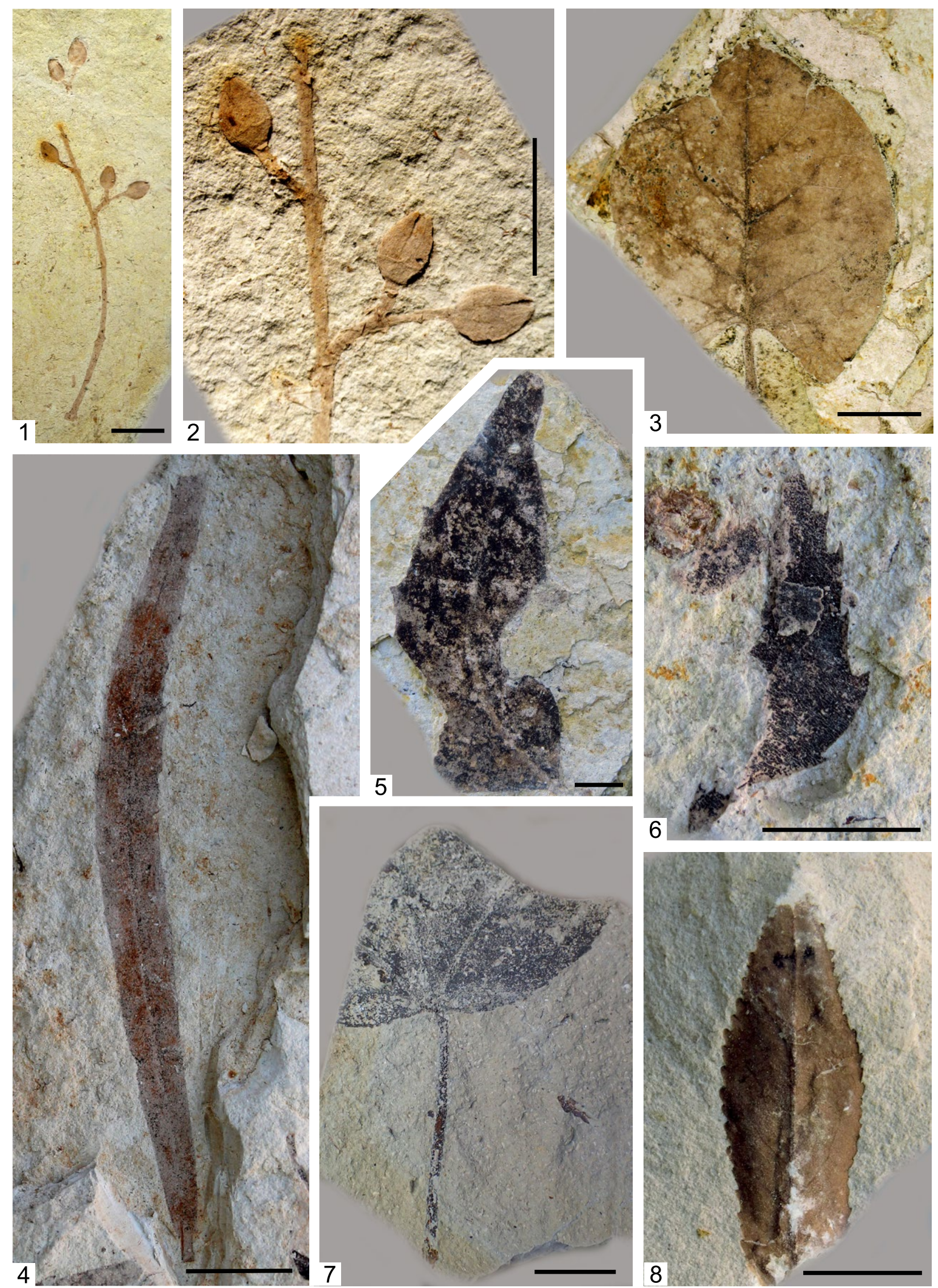

Plate 5. 1, 2. Laurocarpum sp., fruits, 1. PBO 2018.262.1, 2. PBO 2018.262.1; 3. Polygonaceae gen. et sp., leaf, PBO 2019.57.3; 4. Berberis andreanszkyi Kvaček et Erdei, leaf, PBO 2017.145.2; 5, 6. Mahonia sp., leaf, 5. PBO 2017.105.2, 6. PBO 2017.104.1; 7, 8. Liquidambar europaea A. Braun, 7. leaf, PBO 2016.159.1, 8. leaf fragment, PBO 2006.542.1. Scale bar = $1 \mathrm{~cm}$ 
Description. Isolated leaflets, lamina up to $8.6 \mathrm{~cm}$ long, $3.0 \mathrm{~cm}$ wide, curved, asymmetrical. Base acute, apex acute or missing. Venation not visible. Margin dentate, spinose, teeth with long basal side and short apical side, with spinose apex.

Discussion. From the Most Basin, dated as early Miocene, Sakala (2000: pl. 3, fig. 6) mentioned Mahonia sp., the fossil most similar to our specimens. $M$. bilinica Kvaček et Bůžek (Kvaček and Bůžek, 1994) was recorded from Břežánky near Bílina (Czech Republic), and Mahonia sp. (Givulescu, 1998) was recorded from Valea Crisului (Romania). We cannot assign our specimens to one of those two species. In Magyaregregy it is a very rare accessory element.

\section{Altingiaceae}

\section{Liquidambar europaea A. Braun}

Pl. 5, figs 7, 8, Pl. 6, figs 1,2

1836 Liquidambar europaeum A. Braun; A. Braun, p. 513.

1851 Liquidambar europaeum A. Braun; Ettingshausen, p. 15, T.2, fig. 21.

1955 Liquidambar europaea A. Braun; Berger, p. 97, tex.-figs 104, 105.

1959 Liquidambar europaea A. Braun; Andreánszky, p. 69, text-figs 26-30.

1969 Liquidambar europaea A. Braun; Knobloch, p. 94, T. 44. figs 1, 3, 4-7, T 45. figs 1, 2, 6, T. 46, figs 1,4 , T. 59 , f. 2 .

1971-72 Acer séensis Horváth; Horváth p, 42, pl. 6, fig. 4.

1972 Liquidambar europaea A. Braun; Zastawniak, p. 42 , T.10, figs 10,11 , T. 26 , figs 3 , 3a.

1980 Liquidambar europaea A. Braun; Zastawniak, p. 64, T. 8, figs 14-16.

1988 Liquidambar europaea A. Braun; Kovar-Eder, p. 30, T. 2, figs 1-5.

1992a Liquidambar europaea A. Braun; Hably, p.199, Pl. 1, fig. 1.

2013 Liquidambar europaea A. Braun; Hably, p. 46, pl. 5, figs 3-7, pl. 6, figs 1-3.

Material. Abaliget, Kiskốhegy: BPO 2016.159.1, Magyaregregy, Almás-patak: PBO 2006.530.1, 2006.542.1-2006.545.1.

Description. Lamina palmate, five-lobed or fragmented five- or three-lobed. Lamina wider than long. Largest length of central lobe $3.5 \mathrm{~cm}$, original width of whole lamina $6 \mathrm{~cm}$. Side lobes shorter than middle lobe. Base truncate, lobe apices acute. Margin regularly toothed. Teeth simple, small, tooth apices and sinuses rounded. Venation palinactinodromous. Midvein straight and strong, first pair of primaries runs to lower lobes almost perpendicular to midvein and ends in apices of lower lobes. From each primary vein, secondaries diverge in upper half of lobes and form loops near margin.

Discussion. In the Miocene flora of the Mecsek Mts, Liquidambar europaea occurs both in volcanic sediment from Magyaregregy, Almáspatak, and in fish-scale marl from Abaliget, Kiskó-hegy. In Hungary this is the earliest appearance of the species. Later it was recorded in the Sarmatian (Andreánszky, 1959), and its latest occurrence was recorded from several Pannonian localities (Hably, 2013). It was most common during the Pannonian, where it was a characteristic element of hardwood riparian or gallery forests. It was widespread in Europe during the late Miocene, as in the Alpine Molasse floras in Austria (Kovar-Eder, 1988), Moravia (Knobloch, 1969), Chiuzbaia, Romania (Givulescu, 1990), Sośnica, Poland (Göppert, 1855) and Carpathian Ukraine (Iljinskaja, 1968), and in numerous Pliocene floras such as in Willershausen, Germany (Knobloch, 1998) and Domanski Wierch, Poland (Zastawniak, 1972).

\section{Betulaceae}

Ostrya sp. leaf

Pl. 6, fig. 3

Material. Magyaregregy: PBO 2000.489.3.

Description. Simple leaf, lamina length $3.8 \mathrm{~cm}$, width $1.8 \mathrm{~cm}$, apex missing, base missing, margin densely serrate. Teeth small, spaced irregularly, tooth apex acute, sinuses angular. Venation craspedodromous. Secondaries ending in larger tooth apices. In some cases secondaries fork, forming a Y.

Discussion. Ostrya leaf remains are relatively rarely mentioned in the palaeobotanical record. From the late Oligocene flora from Enspel, Köhler and Uhl (2014) mentioned Ostrya atlantidis Unger associated with fruits. From the Miocene flora of the Pětipsy Area (Czech Republic), Ostrya atlantidis was described by Bůžek (1971). A new species, Ostrya licudensis Erw. Knobloch et Velitzelos, was described by Knobloch and Velitzelos (1986) from the late Miocene flora of Likudi 
near Elassona (Greece), but a fruit remain was described as Ostrya atlantidis.

\section{Ostrya sp. involucre}

Pl. 6, figs 4-6

Material. Magyaregregy: PBO 97.78.2, 2017.134.2, 2017.135.2, Magyaregregy, Leány- kói-árok: PBO 2016.109.1, Magyaregregy, Vágyom-völgy: PBO 2017.94.2.

Description. Involucres asymmetrical, ovate, $1.5-2.1 \mathrm{~cm}$ long, $0.55-0.9 \mathrm{~cm}$ wide. Apex obtuse. Five longitudinal veins run from base to apex. Fine cross-veinlets anastomose between longitudinal veins.
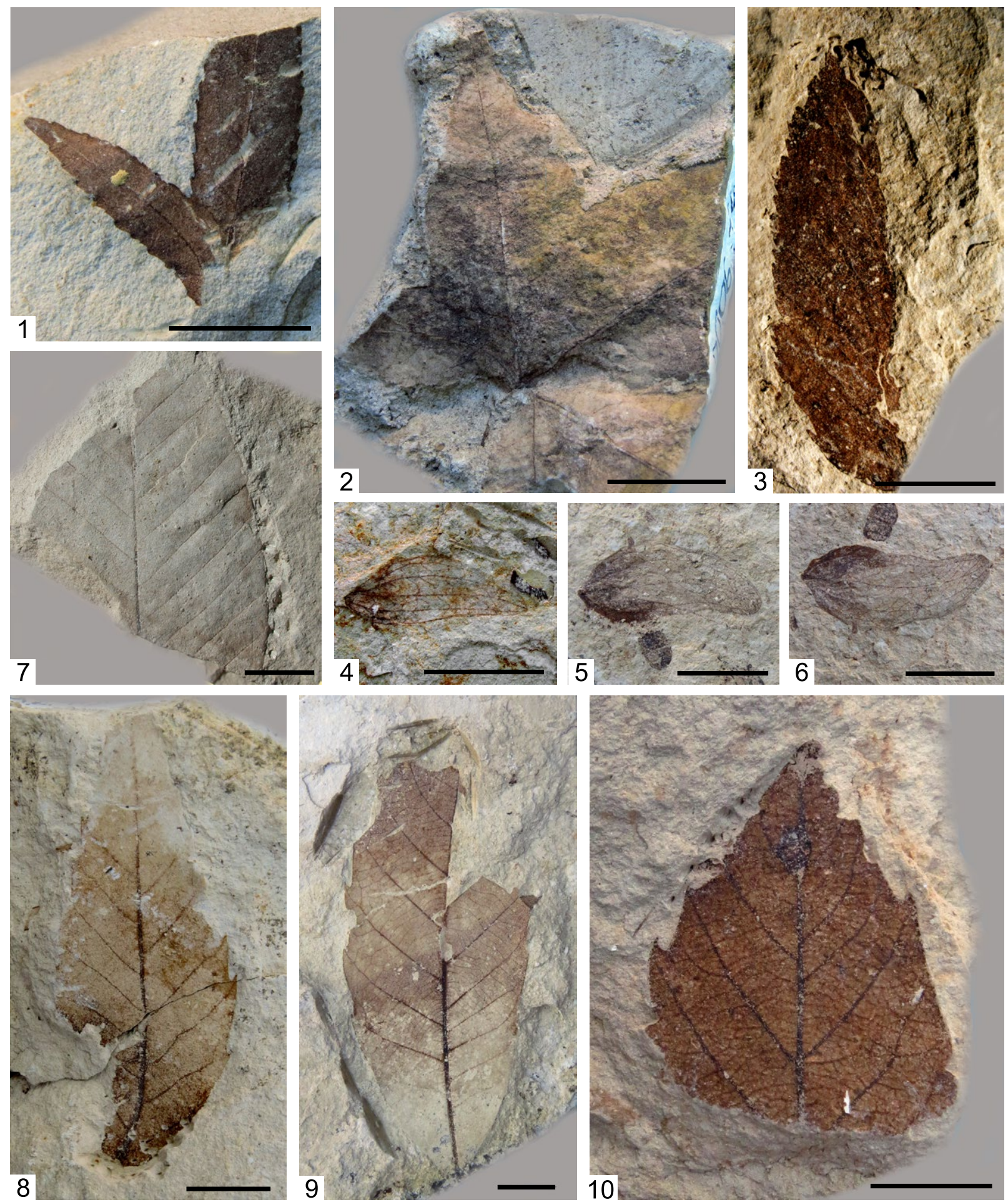

Plate 6. 1, 2. Liquidambar europaea A. Braun, 1. leaf fragment, PBO 2006.544.1, 2. leaf, PBO 2006.545.1; 3-6. Ostrya sp. 3. leaf, PBO 2000.489.3, 4. involucre, PBO 2017.94.2, 5. involucre, PBO 97.78.1, 6. involucre, PBO 97.78.1 counterpart; 7. Fagus sp., leaf fragment, PBO 2002.617.2; 8-10. Quercus kubinyii (Kováts ex Ettingshausen) Berger, 8. leaf, PBO 2001.168.2, 9. leaf, PBO 2007.33.3, 10. leaf fragment, PBO 2003.291.1. Scale bar $=1 \mathrm{~cm}$ 
Discussion. These specimens differ from O. atlantidis Unger in being always asymmetrical and not so broad ovate as in $O$. atlantidis. In the upper part of the specimens there are rounded incisions. O. atlantidis Unger is well known from several late Oligocene-Miocene floras of Europe. It was mentioned from Radoboj (Unger, 1852), from the Pětipsy area in the North Bohemian Basin (Bůžek, 1971), from Likudi near Elassona in Greece (Knobloch and Velitzelos, 1986) and from Enspel in Germany (Köhler and Uhl, 2014). Our involucres differ from $O$. atlantidis, and the leaf probably belongs to the same species as the involucres.

\section{Fagaceae}

\section{Fagus sp.}

Pl. 6, fig. 7

Material. Abaliget, Kiskő-hegy: PBO 2017.32.2, Magyaregregy: PBO 2002.617.2, Magyaregregy, Vágyom-völgy: PBO 2004.136.1.

Description. Fragmentary leaves, apex and base missing. Margin slightly undulate, with very small teeth. Venation craspedodromous. Midvein strong, secondaries regular, parallel with each other, ending in tooth apices.

Discussion. Fagus is very rare in the Miocene flora of Mecsek; only three small fragments were found in the fish-scale marl.

\section{Quercus kubinyii}

(Kováts ex Ettingshausen) Berger

Pl. 6, figs $8-10$, pl. 7, fig. 1

1851 Castanea kubinyii Kováts; Kováts, p. 178.

1852 Castanea kubinyii Kováts; Ettingshausen, p. 6, Pl. 1, fig. 12.

1856 Castanea kubinyii Kováts; Kováts, p. 25, pl. 3, figs $1-7$.

1952 Castanea atavia Unger; Berger, p. 89, figs 37, 39-41.

1952 Quercus cf. Drymeja Unger; Berger, p. 92, figs 48-50.

1952 Quercus kubinyii (Kováts) Berger; p. 92, fig. 47.

1955 Castanea atavia Unger; Berger, p. 91, figs 64-67.

1971-72 Quercus kubinyi (Kováts) Czeczott; Horváth, p. 34 , pl. 2 , figs 4,5 .

1971-72 Quercus castaneaefolia C.A. Mey; Horváth, p. 34, pl. 2, figs 4, 5, text-figs 2, 3b, $4 \mathrm{~b}$.

1972 Quercus kubinyii (Kováts ex Ettingshausen) Berger; Zastawniak, p. 26, pl. 4, fig. 15, pl. 5, figs 7, 8, pl. 21, figs 1-3.

1988 Quercus kubinyii (Kováts ex Ettingshausen)
Berger; Kovar-Eder, p. 35, pl. 5, fig. 1, pl. 3. figs 7, 8.

1997 Quercus kubinyii (Kováts ex Ettingshausen) Czeczott; Hably and Kvaček, p. 23, Pl. 9, figs 37, 38, 40, 41, Pl. 10, figs 42-47.

2013 Quercus kubinyii (Kováts ex Ettingshausen) Berger; Hably, p. 48, pl. 8, figs 4-6.

Material. Abaliget, Kiskô-hegy: PBO 2017.35.2, Kisbattyán: PBO 2012.161.1, Magyaregregy: PBO 2001.168.2, 2001.754.2, 2001.768.2, 2002.632.2, 2003.291.1, 2006.770.2, 2006.771.1, 2007.33.2, 2007.101.2, 2007.113.2, 2013.157.1, 2016.294.2, 2019.81.1, Magyaregregy, Farkasordító-árok: PBO 2016.107.1, Magyaregregy, Leánykói-árok: PBO 2016.108.1, Magyaregregy, Vágyom-völgy: PBO 2004.136.1.

De s cription. Simple leaves, up to $8 \mathrm{~cm}$ long, $3.8 \mathrm{~cm}$ wide. Lamina ovate, lanceolate, base cordate, apex acute, margin toothed. Teeth usually very acuminate, ending in long bristle. Apical side of teeth concave, much shorter than basal side. Basal side convex, sinuses angular to rounded. Venation craspedodromous. Midvein strong, in some cases slightly curved. Several pairs of secondaries branch off midvein and end in tooth apices. Maximum distance between secondaries $1 \mathrm{~cm}$ in middle part of lamina, generally smaller. Densely spaced tertiary veins run perpendicular to secondary veins.

Discussion. This is the first occurrence of Quercus kubinyii in the flora of Hungary. The species became widespread in Sarmatian floras (Kováts, 1856; Andreánszky, 1959; Erdei, 1995; Erdei and Hír, 2002). It was a rare element of late Miocene floras in the Pannonian Basin (Hably, 2013) but was quite frequent along the margin of Lake Pannon (Berger, 1952, 1955; Kovar-Eder, 1988) as well as in numerous late Neogene floras of Europe (Sitar, 1969; Kovar-Eder, 1988). During the Pliocene it reappeared in the basin as a dominant element in, for example, Pliocene crater lakes (Hably and Kvaček, 1997).

\section{Quercus drymeja Unger}

Pl. 7, fig. 4

1847 Quercus drymeja Unger; Unger, p. 113, pl. 32, figs $1,2,4$.

1850a Quercus drymeja Unger; Unger, p. 400.

1850a Juglans hydrophyla Unger; Unger, p. 469.

1850b Juglans hydrophyla Unger; Unger, p. 196, pl. 53, figs 7-9.

1996 Quercus cf. drymeja Unger; Knobloch and Kvaček, p. 52, pl. Pl. 8, fig. 4. 4a. 

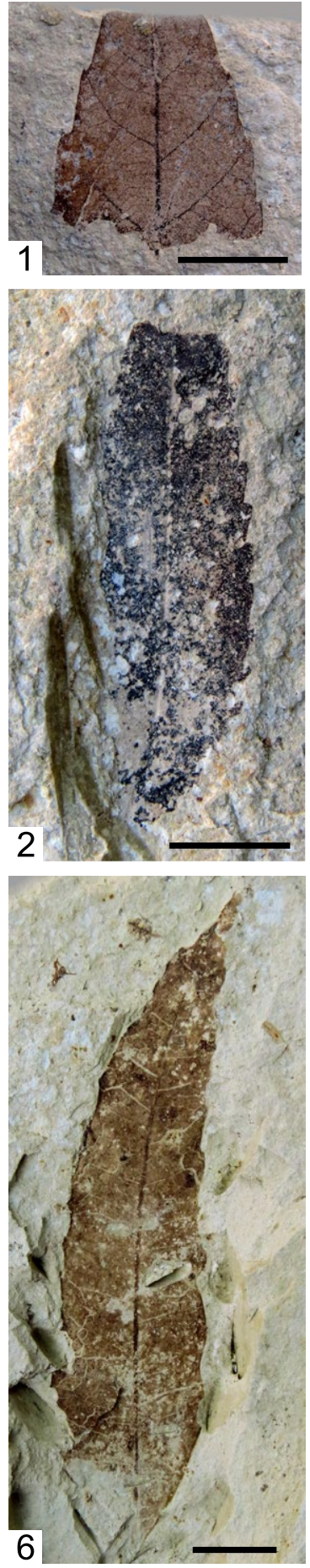
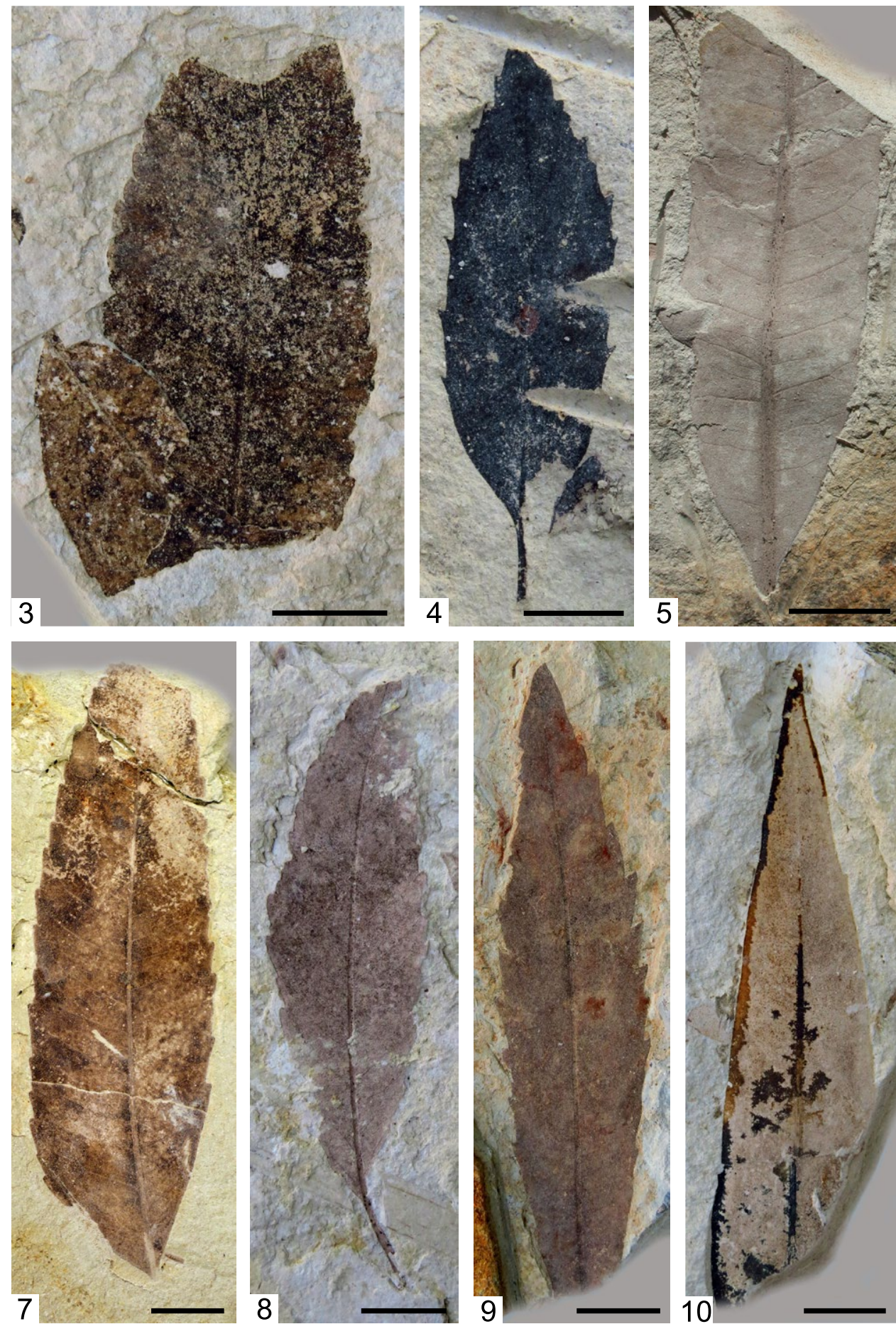

Plate 7. 1. Quercus kubinyii (Kováts ex Ettingshausen) Berger, leaf fragment, $\mathrm{PBO}$ 2006.770.2; 2, 3. Ternstroemites pereger (Unger) Kovar-Eder et Kvaček, leaf, 2. PBO 2016.310.2, 3. PBO 2013.192.1, 4. Quercus drymeja Unger, leaf, PBO 2007.110.1; $\mathbf{5 , 6 , 9 , 1 0 . ~ M y r i c a ~ l i g n i t u m ~ ( U n g e r ) ~ S a p o r t a , ~ l e a f , ~ 5 . ~ P B O ~ 2 0 0 2 . 5 1 9 . 2 , ~ 6 . ~ P B O ~ 2 0 0 2 . 5 3 4 . 2 , ~ 9 . ~ P B O ~ 2 0 1 7 . 9 1 . 1 , ~ 1 0 . ~ P B O ~ 2 0 0 2 . 5 2 0 . 2 ; ~}$ 7, 8. Ternstroemites pereger (Unger) Kovar-Eder et Kvaček, leaf, 7. PBO 2013.196.2, 8. PBO 2013.191.2. Scale bar =1 cm

2004 Quercus drymeja Unger; Kovar-Eder et al., p. 61 , pl. 4, figs $1-7$.

Material. Magyaregregy: PBO 2007.110.1.

Description. Simple petiolate leaf, length of petiole $1.5 \mathrm{~cm}$. Lamina length $4.7 \mathrm{~cm}$, width $1.6 \mathrm{~cm}$. Shape of lamina ovate, base narrow cuneate, apex missing, probably acute. Margin serrate, teeth widely spaced, small, sharp, tooth apices acute to acuminate, apical side of teeth much shorter than basal side. Midvein strong, venation craspedodromous, secondaries depart from midvein regularly. Tertiary venation barely visible.

D i s c u s sion. Only one specimen was found. It was a frequent element of the Sarmatian flora of Erdóbénye (Erdei and Hír, 2002) and was 
recorded from the flora of Parschlug (KovarEder et al., 2004); these leaves are very similar to the form of the leaf described from Magyaregregy. It was recorded also from the late Miocene flora of Vegora, Greece (Kvaček et al., $2002 b$ ), but these leaves are different from the above-mentioned ones; they are much shorter and the teeth are more mucronate. KovarEder et al. (2004) also distinguished different types of leaves. Probably more than one taxon belongs to this form species. According to Denk et al. (2017), the fossil taxon Quercus drymeja should be treated as a morphotype complex which possibly comprised different biological species at different times.

\section{Theaceae}

\section{Ternstroemites pereger}

(Unger) Kovar-Eder et Kvaček

$$
\text { Pl. 7, figs 2, 3, 7, } 8
$$

1850a Carpinus oblonga Unger; Unger, p. 409, pro parte.

1850a Amygdalus pereger Unger; Unger, p. 483, pro parte, basionym.

1850a Crataegus orionis Unger; Unger, p. 481.

1850b Amygdalus pereger Unger; Unger, p.184, pro parte, pl. 55, figs 11, 13, 14.

1852 Carpinus oblonga Unger; Unger, p. 10, pro parte, pl. 20, fig. 16.

1866 Crataegus orionis Unger; Unger, p. 59, pl. 18, fig. 15.

2004 Ternstroemites pereger (Unger) Kovar-Eder et Kvaček; Kovar-Eder et al., p. 63, pl. 6, figs 1-7.

Material. Magyaregregy: PBO 2013.191.1, 2013.192.1, 2016.309.2-216.313.1, 2016.154.1. counterpart of 2013.191.1, 2013.200.1,2019.9.3, 2019.6.1, 2019.23.2-2019.25.2, 2019.52.1, 2019.53.2, 2019.57.3, 2019.93.2, Magyaregregy, Vágyom-völgy: PBO 2017.159.1.

Description. Leaves lanceolate, petiole up to $1.4 \mathrm{~cm}$ long, base slightly asymmetrical, cuneate, apex missing, probably acute. Margin densely, regularly crenulate, entire at base. Teeth small, apical side of teeth shorter than basal side. Venation semicraspedodromous.

Discussion. The leaf remains from Magyaregregy are similar to leaves described from Parschlug (Kovar-Eder et al., 2004). This is the first record of this taxon from the Hungarian Tertiary. The botanical affinity of these fossils is uncertain.

\section{Gordonia sp.}

Pl. 23, figs 11-17

Material. Magyaregregy: PBO 97.142, 2007.22.1, 2017.97.1-2017.101.2, 2017.142.2, 2018.251.2,2018.258.1, 2018.291.1, 2018.369.1, 2019.14.1, Magyaregregy, Vágyom-völgy: PBO 2017.156.1, 2017.157.2.

Description. Winged seeds consisting of an elongate ovate seed body and dorsal elongate wing. Wing swelling on ventral side. Length of winged seeds $0.9-1.7 \mathrm{~cm}$, width up to $0.6 \mathrm{~cm}$, distal end of wing rounded. Seed body up to $0.7 \mathrm{~cm}$ long and up to $0.25 \mathrm{~cm}$ wide, oriented with long axis. Basal part of seed rounded, apical part acute.

Discussion. Winged seeds assigned to Theaceae have not been recorded so far from European floras. Although seeds described as cf. Gordonia sp. occur in Kundratice, Kvaček and Walther (1998) noted that similar seeds had been mentioned as Saportaspermum occidentale from Oregon by Meyer and Manchester (1997). Winged seeds resembling the material from Kundratice were described from the nearby Bechlejovice locality as Saportaspermum sp. (Kvaček and Walther, 2004); they are much more comparable to the genus Saportaspermum than to Gordonia. Seeds assigned to Saportaspermum (Meyer and Manchester, 1997) very probably belong to Malvaceae, but the taxonomic position is uncertain. From Kymi (Greece), small winged fruits originally published as Embothrium salicinum Heer were revised by Velitzelos et al. (2002) as Saportaspermum sp. These seeds show characters very similar to Saportaspermum described by Meyer and Manchester (1997). In Saportaspermum seeds the ventral and dorsal margins of the wing are more or less parallel, which is not the case in the seeds collected in Magyaregregy. In the latter the wing and the seed body are attached slightly obliquely. Seeds of modern Gordonia species show high similarity to our seeds.

\section{Myricaceae}

\section{Myrica lignitum (Unger) Saporta}

Pl. 7, figs 5, 6, 9, 10, pl. 8, figs $1-4$

1847 Quercus lignitum Unger; Unger p. 113, T. 31, figs 5-7. 
1867 Myrica vindobonensis (Ettingshausen) Heer; Unger, p. 46, pl. 4, figs 23-27.

1867 Laurinastrum dubium Unger; Unger, p. 56, pl. 8, fig. 11.

1867 Banksia solonis Unger; Unger, p. 60, pl. 9, fig. 1.

1867 Dryandroides hakeaefolia Unger; Unger, p. 60-61, pl. 9, figs 4-13, 15.

1867 Olea noti Unger; Unger, p. 62, pl. 10, figs 1-12.

1867 Asclepias podalyrii Unger; Unger, p. 63, 64, pl. 10, figs 13-24.

1867 Neritinium longifolium Unger; Unger, p. 63, pl. 10, fig. 25.

1867 Euclea relicta Unger; Unger, p. 68, pl. 11, fig. 39.

1988 Myrica lignitum (Unger) Saporta; Kovar-Eder; p. 41 , T. 10 , fig. 6 .

1990 Myrica lignitum (Unger) Saporta; Kovar-Eder and Krainer; p. 19, pl. 3, figs 1-5, text-fig. 8/1-6.

2013 Myrica lignitum (Unger) Saporta; Hably, p. 55, pl. 15, figs $3-9$, pl. 36, fig. 4 .

Material. Abaliget, Nyáras-völgy: PBO 2016.37.1, Magyaregregy: PBO 97.99.2, 2002.460.2, 2002.501.1-2002.589.2, 2002.591.1 $-2002.593 .2,2002.653 .2-2002.662 .2,2002.947 .2-$ 2002.987.1, 2004.892.1, 2006.734.1, 2007.49.22007.53.1, 2007.103.2, 2007.123.1, 2007.129.2, 2007.130.2, 2007.942.2, 2016.129.1, 2016.130.2, 2016.298.2, 2018.304.1, 2019.9.3, Magyaregregy, Almás-patak: PBO 2006.549.1, Magyaregregy, Farkasordító-árok: PBO 2006.478.1-2006.482.1, 2015.496.1-2015.498.1, 2016.103.1-2016.105.1, cf. 2016.106.1, cf. 2016.124.1, Magyaregregy, Kisréti-árok: PBO cf. 2016.125.1, Magyaregregy, Leánykôi-árok: PBO 2006.445.1, Magyaregregy, Vágyom-völgy: 2002.352.2, 2007.232.2, 2007.233.1, 2017.91.1, 2017.151.1.

Description. Simple lanceolate leaves, length of lamina up to $15 \mathrm{~cm}$, width up to $2.5 \mathrm{~cm}$. Base cuneate, apex acute to attenuate, margin entire to undulate or serrate. Teeth spaced regularly to irregularly, of various size, tooth apex acute to obtuse. Midvein strong, venation camptodromous, brochidodromous in entire-margined leaves, semi-craspedodromous in leaves with toothed margin. Secondaries very fine, densely spaced, spacing opposite or alternate, generally branching out regularly from midvein. Intersecondaries running almost parallel to adjacent secondaries; tertiaries and quaternaries weakly reticulate, forming an irregular network.

Discussion. The leaves of Myrica lignitum vary greatly in Magyaregregy, similarly to those from the type locality in Parschlug (Austria). Generally the leaves are large, with an entire margin or with very small teeth, sometimes with larger ones, similarly to $M$. vindobonensis (Ettinshausen) Heer. Myrica lignitum is one of the most frequent species in the Miocene flora of the Mecsek Mts; it occurs in almost all of the localities. The species was widespread in the Miocene floras of Europe, and preferred wetland areas. From the late Miocene locality Pitsida, Crete (Greece), a unique plant assemblage was described by Zidianakis et al. (2015), where isolated fruits, fruiting stalks with fruit, and bare fruiting stalks were found in a huge mass.

\section{Juglandaceae}

Engelhardia orsbergensis (P. Wessel et C.O. Weber) Jähnichen, Mai et Walther

Pl. 8, figs 5-7, pl. 9, figs 1-4

1856 Banksia orsbergensis P. Wessel et C.O. Weber; Wessel and Weber, p. 146, pl. 25, figs 9a-d.

1916 Sapindus cassoides Ettingshausen; Principi, pl. 63 , figs $6,7,8$.

1916 Sapindus Pythii Unger; Principi, pl. 63, fig. 9.

1977 Engelhardia orsbergensis (P. Wessel et C.O. Weber) Jähnichen, Mai et Walther; Jähnichen et al. p. 323, pl. 9. fig. 4.

1997 Engelhardia orsbergensis (P. Wessel et C.O. Weber) Jähnichen, Mai et Walther; Hably and Kvaček, p. 22, pl. 9, fig. 39.

2011 Engelhardia orsbergensis (P. Wessel et C.O. Weber) Jähnichen, Mai et Walther; Kvaček et al., p. 35, pl. 7, figs 6-9.

Material. Kisbattyán: PBO 2012.164.1, Magyaregregy: PBO 2000.295.2, 2000.297.1, 2000.395.2-2000.398.1, 2000.440.1-2000.442.2, 2000.481.2, 2002.498.2, 2002.499.2, 2002.500.2, 2006.573.2，2007.12.1，2007.104.2，2017.74.1, 2017.75.1, 2017.103.2, 2017.141.2, 2018.268.1, 2018.305.1， 2018.370.2, Magyaregregy, Farkasordító-árok: PBO 2006.503.1, 2006.504.2, Magyaregregy, Leánykôi-árok: PBO 2006.452.1, 2006.453.1, 2016.81.1-2016.83.1.

Description. Leaflets of pinnate leaves. Original length of leaflets up to $8 \mathrm{~cm}$, fragments up to $6.5 \mathrm{~cm}$ long, $1.5 \mathrm{~cm}$ wide. Lamina slightly asymmetrical, ovate, lanceolate. Apex acute, base asymmetrical, acute, in some cases shortly petiolulate. Margin at basal part entire, higher up serrate, teeth small and narrow. Tooth apex acute to acuminate. Apical side of tooth straight to convex, much shorter than the straight or slightly concave basal side. Sinuses angular. Venation camptodromous to semicraspedodromous, midrib strong, slightly 

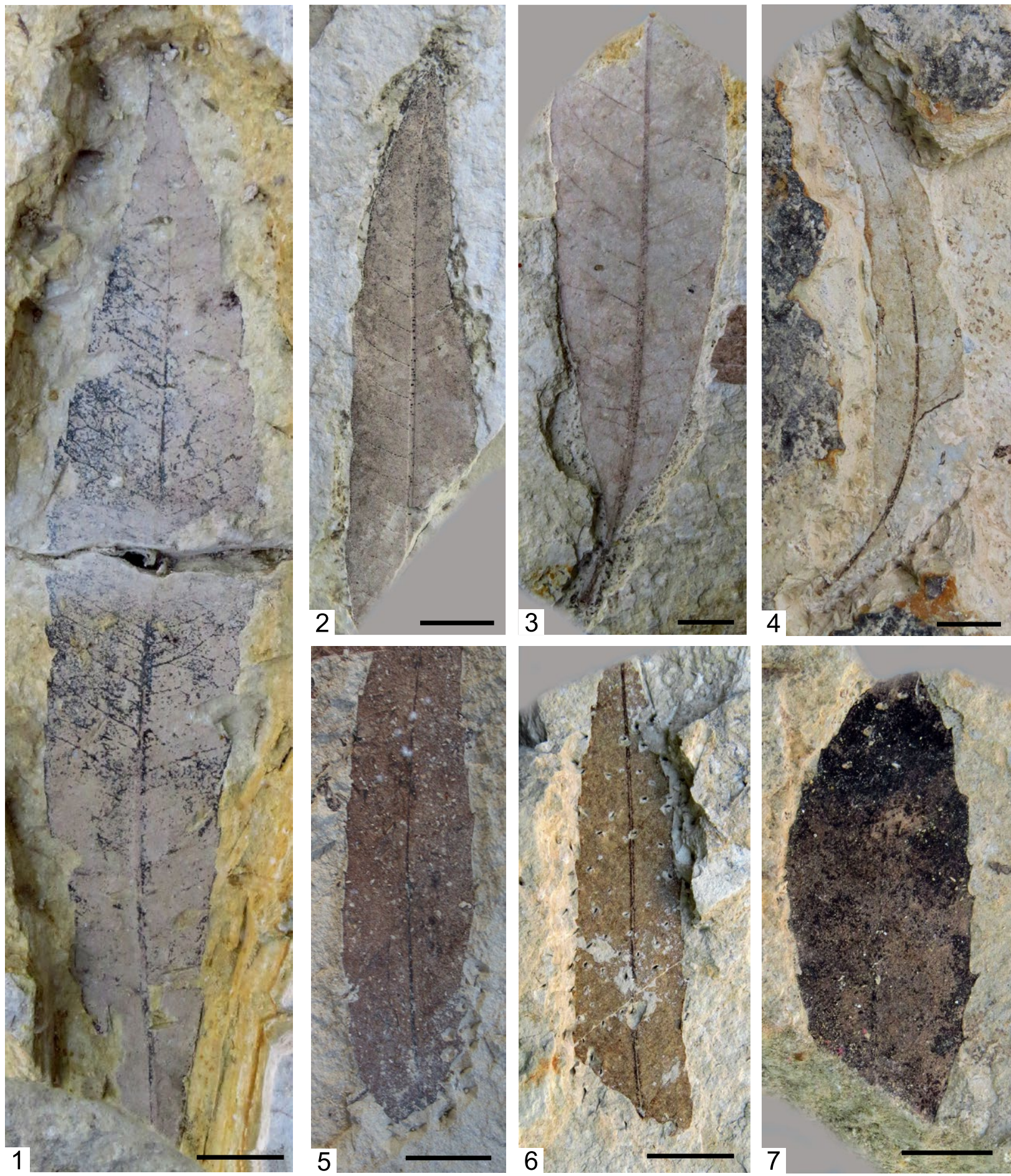

Plate 8. 1-4. Myrica lignitum (Unger) Saporta, leaf, 1. PBO 2002.947.2, 2. PBO 2002.533.2, 3. PBO 2002.979.2, 4. PBO 2002.539.2; 5-7. Engelhardia orsbergensis (P. Wessel et C.O. Weber) Jähnichen, Mai et Walther, leaflet, 5. PBO 2000.295.2, 6. $\mathrm{PBO}$ 2017.74.2, 7. PBO 2017.103.2. Scale bar $=1 \mathrm{~cm}$

curved, secondary veins distinctly thinner, numerous and dense, mostly straight, alternate, looping near margin, intersecondaries parallel with secondaries, thin tertiary veins barely visible.

Discussion. Engelhardia orsbergensis is an accessory element in the Miocene flora of the Mecsek Mts. In the Hungarian Tertiary it appeared in the Eocene floras (Hably, 1985b) and became dominant in the early Oligocene flora of the Tard Clay. In the late Oligocene it was important in some floras such as Kesztölc (Hably, 1988) and Pomáz (Hably, 1994), and became dominant in the early Miocene flora of Ipolytarnóc (Hably, 1985a). Its latest occurrence is known from the Pliocene flora of Gérce (Hably and Kvaček, 1997), as a relict. 
Engelhardia orsbergensis was widespread in thermophilous floras of the European Oligocene and Miocene.

\section{Engelhardia macroptera}

(Brongniart) Unger

Pl. 9, figs 5, 6

1828 Carpinus macroptera Brongniart; Brongniart, p. 48 , pl. 3 , fig. 6 .

1866 Engelhardia macroptera (Brongniart) Unger; Unger, p. 52, pl. 16, figs 9-11.

2000 Engelhardia macroptera (Brongniart) Unger; Sakala, p. 61, pl. 6, fig. 1.

2004 Engelhardia macroptera (Brongniart) Unger; Kovar-Eder et al., p. 65, pl. 6, figs 8, 9.

Material. Kisbattyán: PBO 2012.165.2, Magyaregregy: PBO 2000.296.1, Magyaregregy, Kisréti-árok: PBO 2006.517.1.

Description. Shape of nut rounded, $4 \mathrm{~mm}$ in diameter, carbonized, most of nut missing. Nut surrounded by typical trilobate, entiremargined bract. Bract formed by larger and two smaller lateral lobes. Central lobe $\sim 2 \mathrm{~cm}$ long, slightly broader in upper part, maximum width $0.8 \mathrm{~cm}$. Apex missing. Side lobes $1.4 \mathrm{~cm}$ long, $0.6 \mathrm{~cm}$ wide, apex rounded. Three lobe veins, one in each lobe, middle vein much stronger than lateral veins. Secondaries alternately split off midvein, forking several times and forming loops. Two lateral primary veins join these veins.

Discussion. The angle between the central lobe and the side lobes is much larger in the specimen from Kisbattyán than is usually observed. Even in the other fragmented specimen from Magyaregregy this angle is acute, similarly to several specimens from Parschlug (Kovar-Eder, et al. 2004: pl. 6, figs 8, 9) and the Bílina mine (Sakala, 2000: pl. 6, fig. 1) Fruits of Engelhardia are rarely documented in the Miocene flora of the Mecsek Mts and in several other floras, even if the leaves are frequent (Ipolytarnóc; Hably, 1985a). It is a rare fossil in several Oligocene and Miocene floras of Europe.

\section{Carya serrifolia (Göppert) Kräusel}

Pl. 9, figs 7-9, pl. 10, fig. 2

1855 Quercus serraefolia Göppert; Göppert, p. 17, pl. 5, fig. 14 .

1920 Carya serraefolia (Göppert) Kräusel; Kräusel, p. 389-392, pl. 5, fig. 2.
1964 Carya serraefolia (Göppert) Kräusel; Kolakovski, p. 98, pl. 37, figs 3-5.

1995 Carya serrifolia (Göppert) Kräusel; Kvaček and Walther, p. 31, pl. 4, fig. 3, pl. 6, figs 2 , 3, textfig. $4 / 9$.

2014 Carya serrifolia (Göppert) Kräusel; Köhler and Uhl, p. 19 , pl. 5, fig. 4 . text-fig. 8 .

Material. Magyaregregy: PBO 2002.597.2, 2002.602.2, 2013.194.2, 2013.198.2, 2017.133.2, Magyaregregy, Vágyom-völgy: PBO 2018.371.3, 2019.5.2.

Description. Fragments of leaflets; shape of lamina ovate, apex acute, base missing. Margin serrate, teeth small, dense, irregularly spaced. Apical part of teeth generally shorter than basal side. Tooth apices acute to attenuate. Venation craspedodromous to semicraspedodromous, secondaries depart slightly irregularly, often join each other to form loops before reaching margin (see Köhler and Uhl, 2014: text-fig. 8 c).

Discussion. Carya serrifolia is an accessory element in the Miocene flora of Magyaregregy. It occurs in several Miocene and Oligocene floras of Europe, e.g. Sośnica (Göppert, 1855), Suletice-Berand in northern Bohemia (Kvaček and Walther, 1995), Kodor in Abkhazia (Kolakovski, 1964) and Enspel in western Germany (Köhler and Uhl, 2014). It is difficult to distinguish from Pterocarya denticulata Heer or Carya denticulata (C.O. Weber) Iljinskaja, so there may be several other occurrences of it given under those two names, but the teeth of Pterocarya are more rounded.

Juglandaceae gen. et sp. 1

Pl. 10, figs 1, 4

Material. Magyaregregy: PBO 2002.594.2, 2002.595.1, 2002.599.2, 2002.601.2.

Description. Leaflets up to $10.3 \mathrm{~cm}$ long, $4.8 \mathrm{~cm}$ wide. Shape of lamina ovate, base and apex acute, margin toothed except in basal part. Teeth large, irregular, some of them compound. Tooth apex acute, apical side of teeth shorter than basal side. Sinuses angular to rounded. Venation probably craspedodromous, ending of veins not visible. Midvein strong, secondaries depart from midvein regularly, parallel with each other.

Discussion. The leaf characters suggest the family Juglandaceae. Species in the genus Carya belonging to this family display different teeth. 
Large teeth are also observed in other taxa such as Quercus gigas Göppert, but the base as well as the form of the teeth are different (Walther and Zastawniak, 1991). In the Miocene flora of the Mecsek Mts it is a rare accessory element, occurring only in one locality.

\section{Juglandaceae gen. et sp. 2}

Pl. 10, figs 3, 5

Material. Magyaregregy: PBO 2002.598.2.
Description. Original length of leaflets almost $10 \mathrm{~cm}$, fragments more than $7 \mathrm{~cm}$ long, width up to $4 \mathrm{~cm}$. Leaf petiolate, petiole very short, $1.5 \mathrm{~mm}$ long. Base slightly asymmetrical, cuneate. Apex missing, margin toothed, teeth small, irregular, tooth apex acute to obtuse. Venation craspedodromous to semicraspedodromous, midvein strong, secondaries depart from midvein regularly. Dense tertiary venation visible between secondaries, running perpendicular to secondaries.
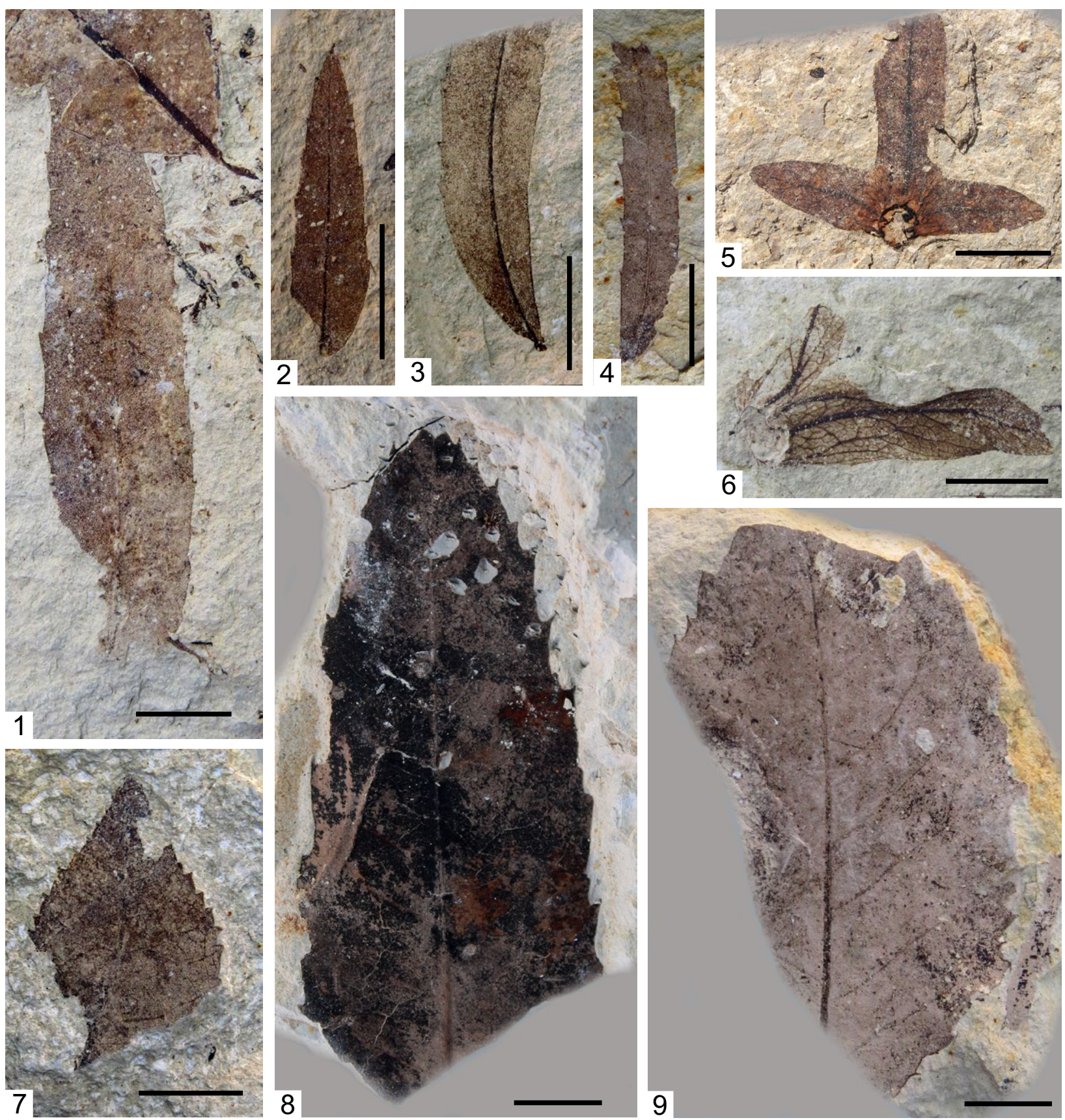

Plate 9. 1-4. Engelhardia orsbergensis (P. Wessel et C.O. Weber) Jähnichen, Mai et Walther, leaflet, 1. PBO 2000.295.2. counterpart, 2. PBO 2000.397.1; 3. PBO 2007.12.1, 4. PBO 2000.395.2; 5, 6. Engelhardia macroptera (Brongniart) Unger, fruit, 5. PBO 2012.165.2, 6. PBO 2000.296.1, 7-9. Carya serrifolia (Göppert) Kräusel, 7. leaflet fragment, PBO 2013.194.2, 8. leaflet, PBO 2019.5.2, 9. leaflet, PBO 2002.602.2. Scale bar $=1 \mathrm{~cm}$ 
Discussion. According to leaf morphology these fragments belong to the family Juglandaceae, but assignment to a genus is not possible. A juglandaceous species occurring in the flora, Carya serrifolia, has more irregular teeth, spaced more densely. Another species, Carya minor Saporta et Marion described from the Miocene flora of Achldorf (Knobloch, 1986), also has teeth spaced much more densely than in the leaf from Magyaregregy.
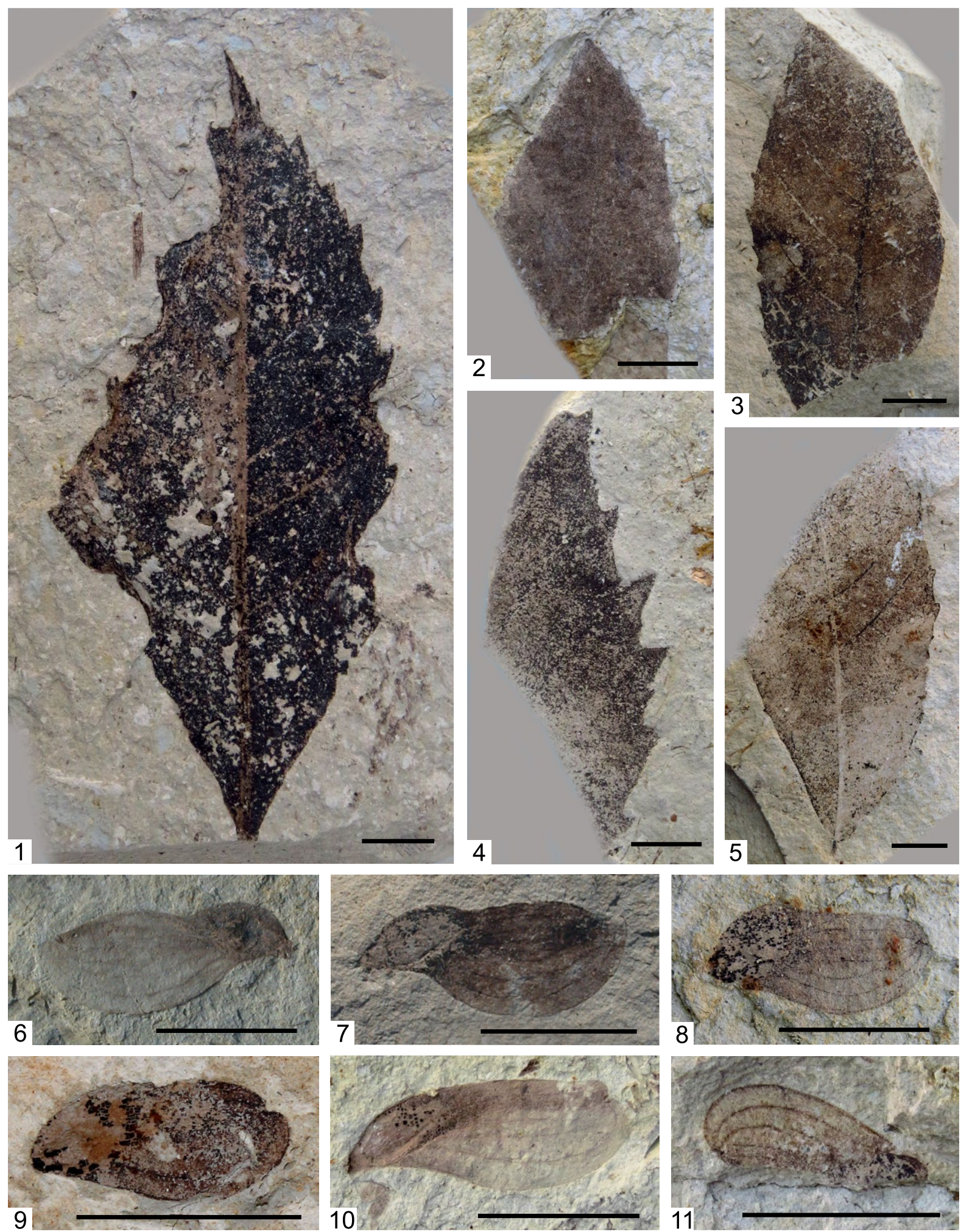

Plate 10. 1, 4. Juglandaceae gen. et sp. 1, leaflet, 1. PBO 2002.595.2, 4. PBO 2002.594.2; 2. Carya serrifolia (Göppert) Kräusel leaflet, PBO 2013.198.2, 3, 5. Juglandaceae gen. et sp. 2, leaflet, 3. PBO 2002.598.2, 5. PBO 2002.598.2. counterpart; 6-11. Cedrelospermum aquense (Saporta) Saporta, fruit, 6. PBO 99.182.1, 7. PBO 97.137.1, 8. PBO 2007.230.2, 9. PBO 2017.146.2, 10. $\mathrm{PBO}$ 2006.748.2, 11. PBO 97.145.1. Scale bar $=1 \mathrm{~cm}$ 


\section{Ulmaceae}

\section{Cedrelospermum aquense Saporta}

\author{
Pl. 10, figs 6-11
}

1862 Embothrites aquensis Saporta; Saporta, p. 260, pl.8, fig. 8.

1867 Embothrites borealis Unger; Saporta, p. 19, pl. 2, figs 13-15.

1888 Embothrium stiriacum Ettingshausen; Ettingshausen, p. 316 , pl. 4, fig. 32 .

1889 Cedrelospermum aquense (Saporta) Saporta; Saporta, p. 93, pl. 18, fig. 11.

1889 Cedrelospermum boreale (Unger) Saporta; Saporta, p. non description, pl. 18, figs 15-17.

2002 Cedrelospermum aquense (Saporta) Saporta; Hably and Thiébaut, p. 79, pl. 1, figs 1-4, pl. 2, figs $1-4$, pl. 3 , figs $1-6$, pl. 4 , figs $1-5$, pl. 5 , figs $1-6$, pl. 6, figs $1-7$.

2004 Cedrelospermum stiriacum (Ettingshausen) Kovar-Eder et Kvaček; Kovar-Eder et al., p. 68, pl. 8 , fig. 6 .

M a te ri a l. Kisbattyán: PBO 2012.166.2, Magyaregregy: PBO 97.137.1-97.145.1, 99.140.199.147.1, $99.149 .1, \quad 99.150 .1, \quad 99.170 .1$, 99.182.1, 99.183.1-99.186.1, 99.417.299.419.2, 2000.207.2, 2000.209.2, 2000.210.2, 2000.212.1-2000.214.2,2000.248.2,2000.400.1, 2000.413.2-2000.415.1,2000.456.1,2000.489.3, 2001.929.2,2002.487.1,2006.430.1-2006.435.1, 2006.570.2-2006.572.2,2006.738.1,2006.748.2, 2006.754.2, 2007.6.1, 2007.7.1, 2007.92.1, 2007.97.2, 2007.98.1, 2013.261.1, 2017.12.1, 2017.13.1, 2018.306.2, 2019.49.1, 2019.55.2, cf. 2019.80.1, Magyaregregy, Farkasordító-árok: PBO 2006.496.1-2006.498.1, cf. 2016.111.1, Magyaregregy, Vágyom-völgy: 2002.361.2, 2007.230.2, 2017.146.2, 2017.147.2.

Description. Fruit samaroid without pedicel. Perianth sometimes persistent. Samaras 11.55-17.42 mm long, 4.50-7.39 $\mathrm{mm}$ wide. Lateral wing $7.62-13.54 \mathrm{~mm}$ long, oriented $5-28^{\circ}$ to long axis of endocarp, with 7-14 subparallel veins. Suture line 5.97-9.66 mm long, oriented $0-8^{\circ}$ to long axis of wing. Endocarp 5.14-7.62 $\mathrm{mm}$ long and $2.77-4.22 \mathrm{~mm}$ wide.

Discussion. In Hungary it was recorded in the Eocene flora of Lábatlan (Kovács, 1959) and in the early Oligocene Tard Clay Formation (Hably and Erdei, 2015) as well as in the Miocene of the Mecsek Mts. This is the youngest (early Miocene) record of the species. Samaras are much more frequent than leaves in the European floras; they were described from many localities as Embothrites borealis.
Kovar-Eder et al. (2004) described C. stiriacum comb. nov. from Parschlug, Styria, Austria, and distinguished the fruits from those recorded from Magyaregregy based on the difference in size and the narrower base of the former. I and my colleagues studied the morphological variability of $C$. aquense based on specimens recorded from other localities including the Tard Clay (Budapest, Hungary) early Oligocene and Céreste (France) Oligocene. We found that $C$. stiriacum conforms to the morphology of $C$. aquense. In Europe it was recorded in the Eocene floras of Messel, Häring, Telč and Kučlin, in the Oligocene floras of Rott, EgerKiseged, Budapest-Óbuda and Céreste, and in the Miocene floras of Radoboj, Leoben, Parschlug, Schönegg, Randecker Maar and Kymi. Outside Europe, the fruits - under a different species name - are present in several localities in North America (Manchester, 1989) and in Asia (Jia et al., 2015). Cedrelospermum must have had a broad climatic tolerance, thriving in tropical and subtropical rain forests, seasonally dry tropical forests, and warm-temperate mixed mesophytic forests (Manchester, 1989).

\section{Cedrelospermum flichei}

(Saporta) Hably et Thiébaut

$$
\text { Pl. 11, figs 1-12 }
$$

1891 Hemiptelea flichei Saporta; Saporta, p. 74, 75, pl. 20, fig. 5.

1891 Microptelea reperta Saporta, Saporta, p. 74, pl. 17, fig. 2.

2002 Cedrelospermum flichei (Saporta) Hably et Thiébaut, p. 81, pl. 4, figs 6,7 , pl. 7, figs $1-9$.

Material. Magyaregregy: PBO 97.146.197.151.1,99.151.1-99.155.1,99.158.2-99.169.2, 99.171.1-99.174.2,99.181.1,99.190.1-99.192.2, 99.420.1-99.423.1, 2000.206.1, 2000.208.1, $2000.211 .1,2000.213 .2,2000.215 .1,2000.411 .2$, 2000.412.2,2000.437.2-2000.439.2,2000.455.2, 2000.487.1, 2000.488.1, 2001.763.2, 2001.930.1, 2001.931.2, 2002.486.1, 2002.614.2, 2002.960.2, 2006.519.1,2006.571.2,2006.754.2-2006.760.2, $2007.8 .1, \quad 2007.9 .1, \quad 2007.26 .2, \quad 2007.93 .1-$ 2007.96.2, 2007.115.2-2007.118.2, 2012.221.2, 2016.152.2, 2016.299.1, 2016.300.1, 2017.4.2, 2017.14.1, 2017.15.1, 2017.73.1, 2017.143.1, 2018.266.2, 2018.267.1, 2019.13.1, 2019.17.2, 2019.79.2, Magyaregregy, Vágyom-völgy: PBO 2002.351.2, 2004.123.2.

Description. Simple leaves, lamina length $0.9-4.6 \mathrm{~cm}$, width $0.5-1.7 \mathrm{~cm}$, petiole up to 

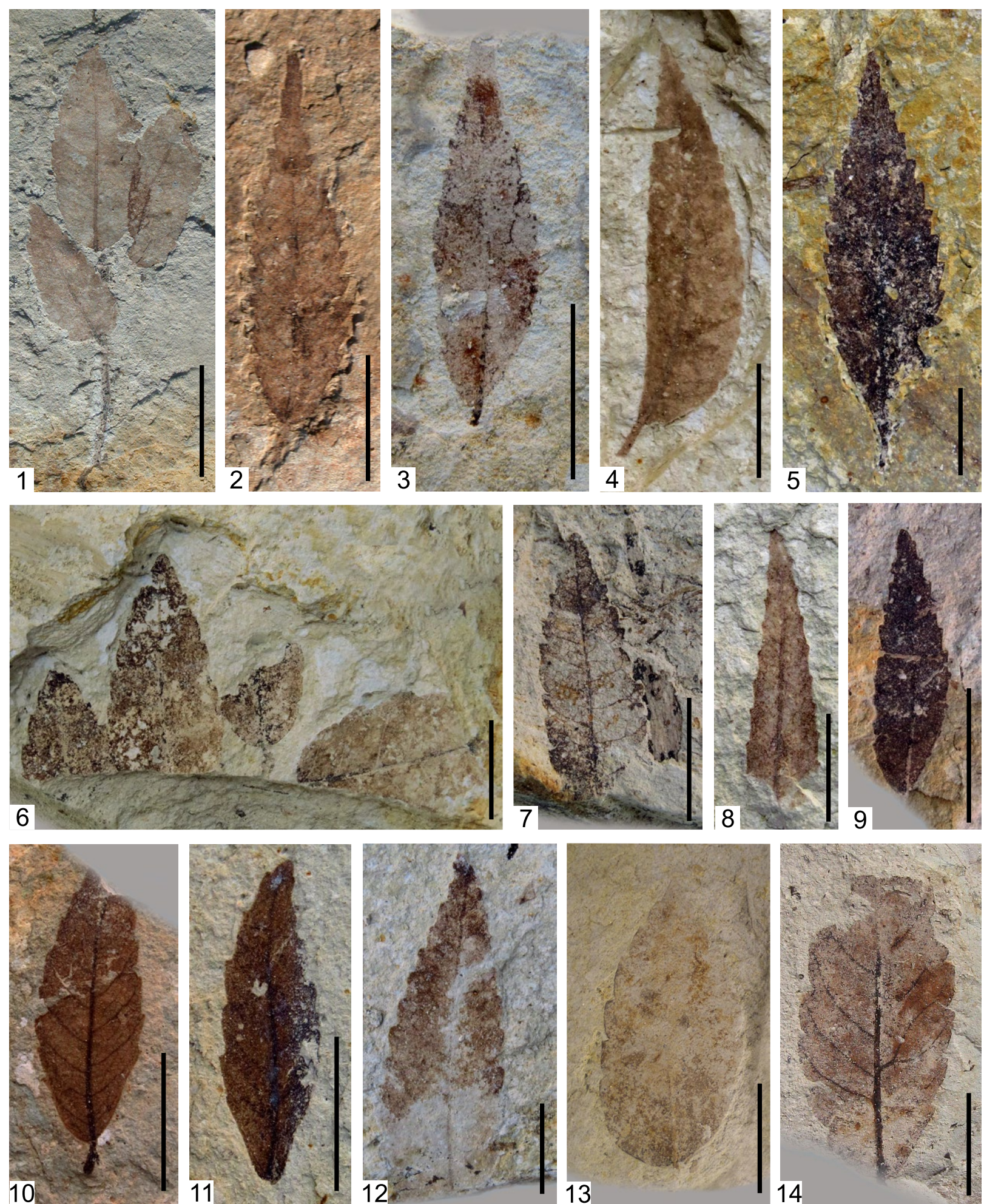

Plate 11. 1-12. Cedrelospermum flichei (Saporta) Hably et Thiebaut, leaf, 1. PBO 99.421.2, 2. PBO 97.149.1, 3. PBO 2004.123.2, 4. PBO 99.154.2, 5. PBO 99.174.2, 6. PBO 99.160.1, 7. PBO 97.150.1, 8. PBO 2012.221.2, 9. PBO 2000.411.2, 10. PBO 2000.211.1, 11. PBO 2007.94.2, 12. PBO 97.147.2; 13, 14. Zelkova zelkovifolia (Unger) Bůžek et Kotlába, leaf, 13. PBO 2016.158.3, 14. PBO 2002.488.2. Scale bar $=1 \mathrm{~cm}$

$2.5 \mathrm{~cm}$. Shape of lamina lanceolate, rarely narrow ovate. Base asymmetrical, cuneate, apex acute, often attenuate. Leaf margin toothed, teeth small, dense, sinuses angular to rounded, spacing regular. Teeth simple, tooth apex acute to obtuse, apical side of teeth straight to convex, basal side convex. Venation craspedodromous, midvein strong, in several cases slightly curved. Secondaries run toward margin and end in tooth apex. Some secondaries diverge at different distances from leaf margin. Tertiary venation random reticulate and barely visible. 
Discussion. The species is dominant in Magyaregregy, accompanied by the fruits of Cedrelospermum aquense. In Europe it was recorded from several localities including Céreste (France, early Oligocene), the Tard Clay Formation (Hungary, early Oligocene) (Hably and Thiébaut, 2002), the late Oligocene flora of Rott, and the Miocene floras of Randecker Maar, Kymi and the Cheb Basin (Hably and Thiébaut, 2002). Several species were described from North America (Manchester, 1989). Cedrelospermum must have had a broad climatic tolerance.

\section{Zelkova zelkovifolia \\ (Unger) Bůžek et Kotlába}

Pl. 11, figs 13,14 , pl. 12, figs 1-3, 6

1843 Ulmus zelkovaefolia Unger; partim Unger, pl. 24, figs 9-13, non fig. 7 (fructus).

1851 Planera Ungeri Ettingshausen; Anonymo ref. Ettingshausen, p. 145.

1856 Zelkova Ungeri Kováts; Kováts, p. 27, pl. 5, figs $1-12$, pl. 6, figs 1-6.

1936 Zelkova Ungeri Kováts; Pop, p. 71, pl. 7, fig. 2, pl. 18, figs 1-5.

1959 Zelkova ungeri Kováts; Andreánszky, p. 133, pl. 37, fig. 5, pl. 39, fig. 6, pl. 41, figs 1,2 .

1971 Zelkova zelkovaefolia (Unger) Bůžek et Kotlába; Bůžek, p. 58, pl. 21, figs 8-9, pl. 22, figs 4-14, text-fig. 5 .

1991 Zelkova zelkovaefolia (Unger) Bůžek et Kotlába; Fischer and Hably, p. 29, pl. 2, figs 1-3, 5, textfigs 19, 23.

?1991 Ulmus sp. 2; Fischer and Hably, p. 30, pl. 1, fig. 8, text-fig. 17.

?1991 Ulmus sp. 3; Fischer and Hably, p. 30, pl. 1, fig. 9, text-fig. 16.

1994 Zelkova zelkovifolia (Unger) Bůžek et Kotlába; Kvaček et al., p. 79, pl. 1, fig. 6.

1997 Zelkova zelkovifolia (Unger) Bůžek et Kotlába; Hably and Kvaček, p. 34, pl. 15, figs 76-80, pl. 16, figs 81-83, p. 57, pl. 31, fig. 162 .

2004 Zelkova zelkovifolia (Unger) Bůžek et Kotlába; Kovar-Eder et al., p. 69, pl. 8, figs 8-11.

2013 Zelkova zelkovifolia (Unger) Bůžek et Kotlába; Hably, p. 57, pl. 34, figs 1, 7, pl. 35, fig. 1.

Material. Abaliget, Kiskó-hegy: PBO 2017.36.1, Abaliget, Nyáras-völgy: PBO 2016.36.1, Kisbeszterce: PBO 2006.400.2, Magyaregregy: PBO 2000.493.1, 2001.754.22001.761.2,2001.932.2,2002.471.1-2002.474.2, 2002.488.2, 2002.625.1, 2006.485.1, 2007.99.2, 2016.144.2,2016.145.1,2016.301.2-2016.304.2, 2017.81.1, cf. 2018.261.2, 2018.309.1, cf. 2018.325.2, cf. 2018.326.1, 2019.7.1, 2019.82.2, Magyaregregy, Farkasordító-árok:
PBO 2006.485.1, 2016.113.2, Magyaregregy, Leánykôi-árok: $\quad$ PBO 2016.87.1-2016.90.1, Magyaregregy, Vágyom-völgy: PBO 2002.362.2, 2007.223.2-2007.225.1, 2017.158.2, fruit: Magyaregregy, Vágyom-völgy: 2007.223.2.

Des cription. Up to $4 \mathrm{~cm}$, with leaves or both leaves and fruits. Simple leaves, up to $3.5 \mathrm{~cm}$ long and $1.5 \mathrm{~cm}$ wide. Lamina shape ovate to elliptic, slightly asymmetrical to symmetrical. Apex acute, base rounded, margin toothed. Teeth simple, large, regular. Tooth apex acute, sometimes mucronate, apical as well as basal side of teeth convex, apical side shorter than basal side. Sinuses angular. Venation craspedodromous. Several pairs of secondaries depart from strong midvein toward margin, ending in tooth apices. Some secondaries bifurcate near midvein. Drupes rarely remain in leaf axils. Maximum diameter of drupes $0.5 \mathrm{~cm}$.

Discussion. In Hungary, Zelkova zelkovifolia appears first in the Egerian (late Oligocene) floras (Hably, 1982, 1988, 1990), then in the Karpatian flora of the Mecsek Mts, but it became dominant only in the Sarmatian floras (Kováts, 1856; Erdei, 1995; Erdei and Hír, 2002). During the Pannonian its area became restricted; it survived in marginal areas of the Pannonian Basin and on inselbergs (Hably, 2013). The species reappeared in volcanic Pliocene floras, for example Gérce, again as a dominant element (Hably and Kvaček, 1997). Zelkova zelkovifolia is a wide-spread element of European Tertiary floras.

\section{Ulmus div. sp. leaf}

Pl. 12, fig. 4

Material. Magyaregregy: PBO 2000.451.22000.454.1, 2000.482.2, 2000.483.2, 2001.937.2, 2002.491.1, 2002.492.2, 2006.447.1, 2006.448.1, $2006.499 .1, \quad 2006.502 .1, \quad 2006.538 .1, \quad$ cf. 2007.571, cf. 2017.71.2, 2018.324.2, Magyaregregy, Almás-patak: PBO 2006.538.1, Magyaregregy, Farkasordító-árok: PBO 2006.499.1, 2006.502.1, Magyaregregy, Leánykóí-árok: PBO 2006.447.1, 2006.448.1, Magyaregregy, Vágyom-völgy: PBO 2002.354.1.

Description. Leaves up to $7 \mathrm{~cm}$ long and $3.8 \mathrm{~cm}$ wide. Shape of lamina ovate, apex acute or missing, base missing, margin toothed. Venation craspedodromous, secondaries in several cases bifurcate, forming a $\mathrm{Y}$ shape. 

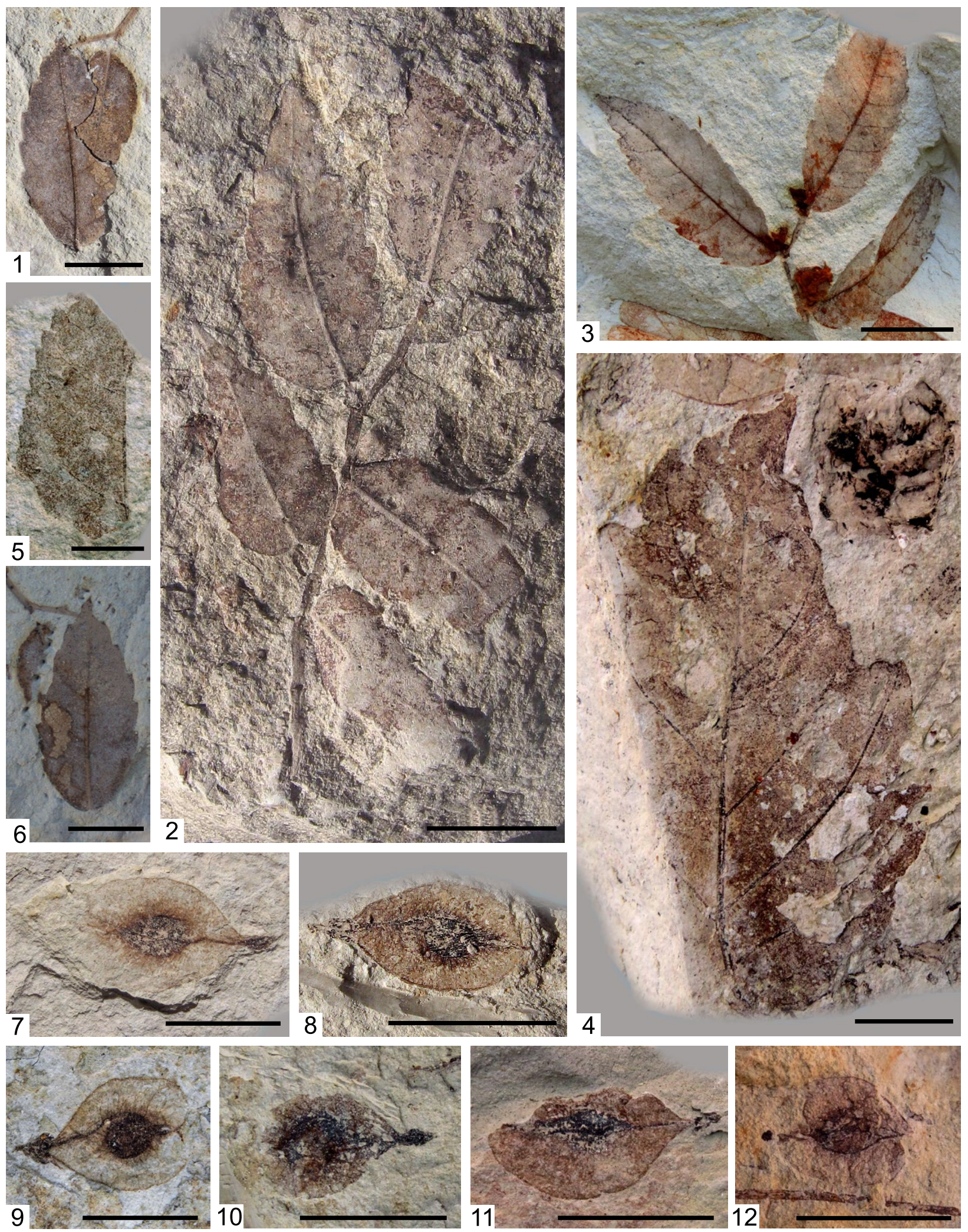

Plate 12. 1-3, 6. Zelkova zelkovifolia (Unger) Bůžek et Kotlába, 1. leaf, PBO 2001.754.2, 2. attached leaves on a twig, PBO 2001.759.1, 3. attached leaves and fruits on a twig, PBO 2007.223.2, 6. leaf, PBO 2001.754.2; 4, 7-12. Ulmus sp., 4. leaf, 2000.451.2, 7. fruit, PBO 2006.578.2, 8. fruit, PBO 2006.737.2, 9. fruit, PBO 2004.127.2, 10. fruit, PBO 2000.291.1, 11. fruit, PBO 2003.250.1, 12. fruit, PBO 2000.290.1; 5. Ulmus braunii Heer, leaf fragment, 2007.114.1. Scale bar $=1 \mathrm{~cm}$

Discussion. These are fragmented or poorly preserved leaves belonging to various species. The genus Ulmus is well represented in the Miocene flora of the Mecsek Mts. Both leaves and fruits occur in high numbers in Magyaregregy. These plants probably were members of wetland habitats, especially of riparian vegetation. 


\section{Ulmus braunii Heer}

Pl. 12, fig. 5

1856 Ulmus braunii Heer; Heer, p. 59, pl. 79, figs 14-21.

1856 Ulmus plurinervia Unger; Kováts, p. 26, pl. 4, figs 8-13.

1989 Ulmus braunii Heer; Sitar et al., p. 50, pl. 29, figs 11-13, 15-16.

1991 Ulmus ruszovensis Hummel; Fischer and Hably, p. 29, pl. 1, figs $2-7$, pl. 2, fig. 4, text-figs 12-15.

1991 Ulmus sp. 1; Fischer and Hably, p. 29, pl. 5, fig. 1, text-fig. 18 .

1994 Ulmus ruszovensis Hummel; Kvaček et al., p. 79.

1997 Ulmus braunii Heer; Hably and Kvaček, p. 32, pl. 14, figs 68-72, text-figs 16-19.

Material. Magyaregregy: PBO 2007.114.1, 2016.155.1.

Description. Fragmented leaves; original length up to $6 \mathrm{~cm}$, width $3 \mathrm{~cm}$. Apex and base missing, margin double serrate, rarely with simple teeth, venation craspedodromous.

Discussion. Relatively small leaves with dense secondary venation have been recorded in Miocene as well as Pliocene floras of Europe. In Hungary it was documented as a dominant element in the Pliocene flora of Gérce (Hably and Kvaček, 1997).

\section{Ulmus sp. fruits}

Pl. 12, figs 7-12

Material. Magyaregregy: PBO 2000.287.22000.294.2, 2001.765.2, 2001.766.1, 2002.491.1, 2003.250.1, 2006.578.2, 2006.737.2, 2006.738.1, 2007.31.2, 2007.106.2, 2018.259.2, 2018.260.2, 2019.16.1, Magyaregregy, Vágyom-völgy: PBO 2002.366.2, 2004.126.2-2004.127.2.

Description. Fruits up to $1.5 \mathrm{~cm}$ long, $0.9 \mathrm{~cm}$ wide, with peripheral wing with wide incision in distal part near style, the perigone shifted slightly downward of peduncle under fruit base.

Discussion. In the Mecsek Mts, Ulmus fruits occur only in the fish-scale marl. The assemblage from Magyaregregy is relatively rich in these fruits. An identical fruit type is also known from the Miocene of Bohemia (Bůžek, 1971; Bůžek et al., 1996).

\section{Ulmaceae gen. et sp.}

1997 Ulmaceae gen. et sp.; Hably et Kvaček, p. 57, pl. 32, figs 163-165, pl. 33, figs 169, 171, textfig. 53 .
Material. Kisbattyán: PBO 2012.167.1.

Description. Simple leaf; lamina shape ovate, apex acute, base obtuse, margin simple serrate. Secondary or higher venation not visible.

Discussion. The teeth are different from those of Zelkova zelkovifolia. Similar leaves were mentioned from the Pliocene flora of Pula, Hungary (Hably and Kvaček, 1997).

\section{Salicaceae}

\section{Populus populina}

(Brongniart) Erw. Knobloch

Pl. 13, figs $1-3$

1822 Phyllites populina Brongniart, p. 237, pl. 14, fig. 4. 1971-72 Populus cf. tremula L.; Horváth, p. 39, pl. 5, fig. 5, text-fig. 4.

1988 Populus populina (Brongniart) Erw. Knobloch; Kovar-Eder, p. 53, pl. 10, figs 13-15.

1997 Populus populina (Brongniart) Erw. Knobloch; Hably and Kvaček, p. 48, pl. 25, fig. 129, pl. 26, fig. 133, pl. 27, fig. 136, pl. 28, fig. 140.

2004 Populus populina (Brongniart) Erw. Knobloch; Kovar-Eder et al., p. 70, pl. 8, fig. 18, pl. 14, fig. 1.

2013 Populus populina (Brongniart) Erw. Knobloch; Hably, p. 66, pl. 29, fig. 2.

Material. Kisbeszterce: PBO 99.288.1, Magyaregregy: PBO 2000.491.1, 2002.623.1, 2006.466.1, 2013.160.1,2013.162.2, 2016.307.1, 2018.307.1, Magyaregregy, Leánykôi-árok: PBO 2016.86.1.

Description. Fragmentary leaves, middle and apical parts of lamina. Apex acute to obtuse, base missing. Margin crenate, smoothly rounded, without pointed apex, sinuses rounded. Tooth apices glanduliferous, especially well visible in specimen PBO 2002.623.1. Venation semicraspedodromous. Midvein strong, several pairs of secondaries run from midvein, forming compound loops near margin, and small veins end at leaf margin. Dense tertiary venation visible between secondaries.

Discussion. This is the first occurrence of the species in the Pannonian Basin. Later it became frequent in the Badenian flora of Nógrádszakál (Andreánszky, 1959). It survived up to the Pliocene (Hably and Kvaček, 1997). During the late Miocene it was more frequent in extrabasinal floras of the surrounding areas than in the basin (Hably, 2013), although it is a riparian element. 


\section{Populus zaddachii Heer}

Pl. 13, figs 4, 5

1859 Populus Zaddachi Heer; Heer, p. 307.

1961 Populus zaddachi Heer; Erw. Knobloch, p. 254, pl. 12, fig. 9, pl. 13, fig. 5, pl. 14, figs 2, 7 .

1995 Populus zaddachii Heer; Kvaček and Walther, p. 39, pl. 4, fig. 5 .

1998 Populus zaddachii Heer; Kvaček and Walther, p. 24 , pl. 13, fig. 3 .

2005 Populus zaddachii Heer; Budantsev, p. 85, pl. 30, figs $1-8$, pl. 31, figs $1-4$.

2006 Populus zaddachii Heer; Reuschel and Walther, p. 9, pl. 7, figs $1-3$, pl. 8, figs 1,2 .

Material. Magyaregregy, Vágyom-völgy: PBO 2017.93.2, 2017.96.1.
Description. Simple petiolate leaf, petiole $3.2 \mathrm{~cm}$ long. Lamina shape ovate, $4.9 \mathrm{~cm}$ long, $3.5 \mathrm{~cm}$ wide. Apex acute, base cordate, margin crenulate. Teeth small, regular, densely spaced. Apex of teeth obtuse, sinuses rounded. Venation acrodromous, with three primaries starting from the very base, lateral bent towards apex, side veinlets widely spaced, entering teeth.

Discussion. P. zaddachii occurs in several Oligocene floras in Germany (Saxony) as well as in the Czech Republic. In the floral assemblage of Thierbach it is an important element of riverside woodland (Reuschel and Walther, 2006). In the Oligocene volcanic floras of the
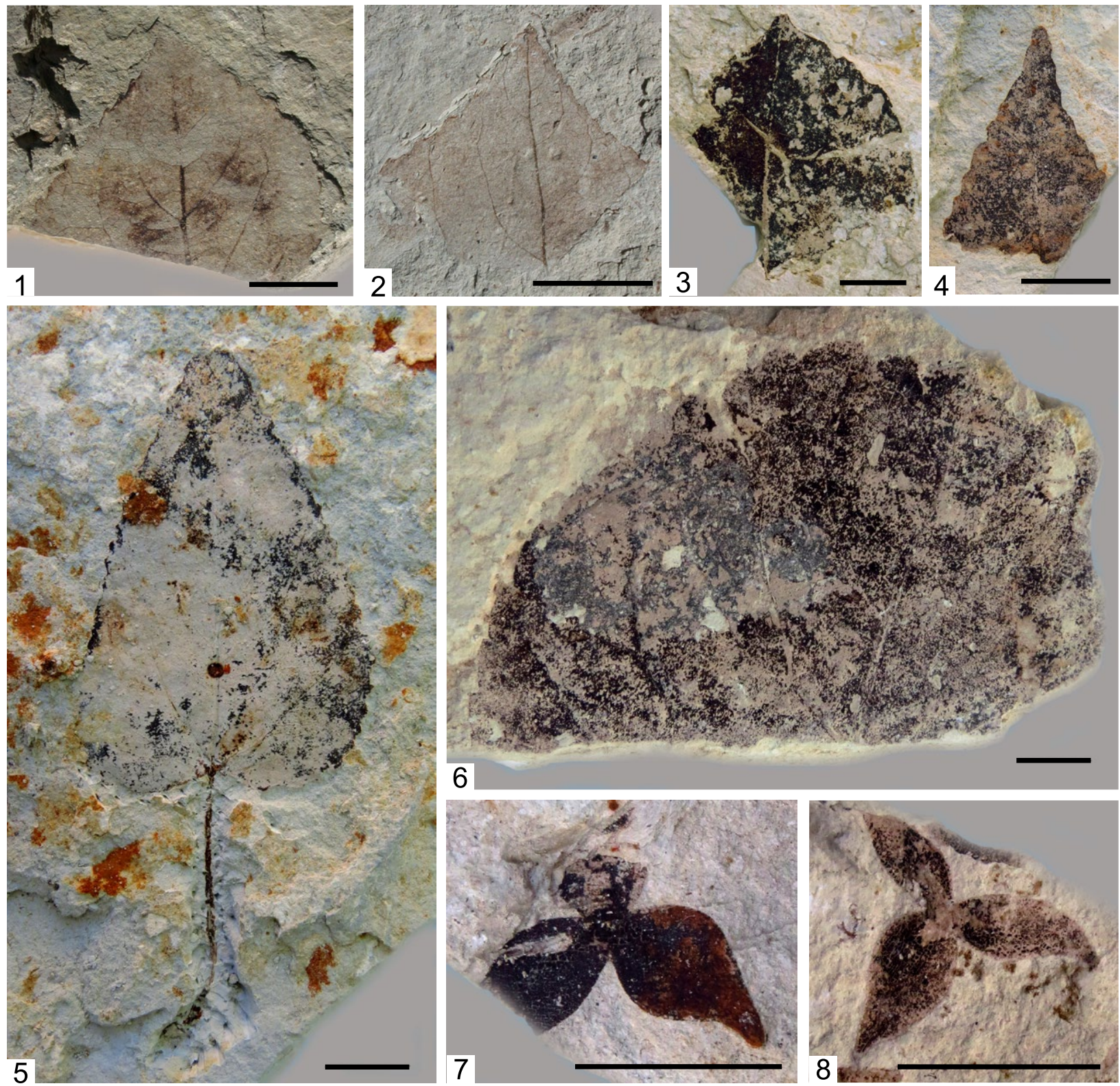

Plate 13. 1-3. Populus populina (Brongniart) Erw. Knobloch, leaf fragment, 1. PBO 2000.491.1, 2. PBO 2002.623.1, 3. PBO 2013.160.1; 4, 5. Populus zaddachii Heer, leaf fragment, 4. PBO 2017.96.1, 5. PBO 2017.93.2; 6. Populus balsamoides Goeppert, leaf fragment, PBO 2002.624.2; 7, 8. Populus sp., fruit, 7. PBO 2013.159.1, 8. PBO 2013.158.1. Scale bar = $1 \mathrm{~cm}$ 
České Středohořý Mts (Czech Republic) and southeastern Upper Lusatia, Saxony (Germany) it was only an accessory element of mixed mesophytic forests: Knížecí = Pirskenberg (Knobloch, 1961), Bechlejovice (Knobloch, 1994) and Kundratice (Kvaček and Walther, 1998). This is the only record from the Miocene. In Magyaregregy it was a rare accessory element, probably having survived in the Mecsek Mts as a relict.

\section{Populus balsamoides Göppert}

$$
\text { Pl. 13, fig. } 6
$$

1855 Populus balsamoides Göppert; Göppert, p. 23, pl. 15, figs 5, 6 .

1965 Populus balsamoides Göppert; Kristofovich and Baikovskaja, p. 25, pl. 1, figs 3-7.

1996 Populus cf. balsamoides Göppert; Erw. Knobloch and Kvaček, p. 59, pl. 15, fig. 11.

Material. Magyaregregy: PBO 2002.624.2.

Description. Apical part of large leaf. Original length more than $10 \mathrm{~cm}$, width $10 \mathrm{~cm}$. Apical part of lamina wide, rounded, apex missing. Venation semicraspedodromous; secondaries join each other, forming loops, finally ending in tooth apices. Teeth large, apex of teeth acute.

Discussion. The original material from Sośnica (Schossnitz, southwestern Poland, Silesia; Göppert, 1855) includes small leaves, but large poplar leaves were described under this name later in the palaeobotanical literature. These large leaves apparently differ from leaves of $P$. populina. The taxonomic position of this species is questionable. In several cases, large leaves of $P$. populina are mentioned as P. balsamoides (Andreánszky, 1959). The only specimen from Magyaregregy differs from $P$. populina in the shape of the lamina and in the form of the teeth.

Populus sp. fruit

Pl. 13, figs 7,8

Material. Magyaregregy: PBO 2013.158.1, 2013.159.1, 2017.140.1, cf. 2019.76.1.

Description. Capsules open, short-stalked, trivalvate. Valves elliptical, $0.7-0.8 \mathrm{~cm}$ long, $0.3-0.5 \mathrm{~cm}$ wide, apex of valves acute.

Discussion. Similar fossils were described from the Karpatian-early Badenian flora of Parschlug (Kovar-Eder, et al. 2004: pl. 8, figs 19-21). In this locality, only leaf remains of Populus populina were documented, so the authors assumed that the capsules belong to $P$. populina. In the flora of Magyaregregy there are leaves representing several species of Populus, among them both P. populina and $P$. balsamoides. In this case it is unclear which species the capsules belong to.

Populus sp. catkin

Pl. 14, fig. 1

Material. Magyaregregy: PBO 2013.199.2.

D e s c r i p ti o n. Catkin, $2.6 \mathrm{~cm}$ long, $0.6 \mathrm{~cm}$ wide.

Discussion. Only one specimen was found in the assemblage. This remain is also rarely mentioned in the palaeobotanical literature.

\section{Buxaceae}

\section{Buxus sp.}

Pl. 14, figs 2, 3

Material. Magyaregregy: PBO 2002.603.22002.607.2, 2016.153.2, cf. 2018.234.1, 2019.56.1.

Description. Simple leaves; shape of lamina obovate, apex emarginate, base decurrent. Length of lamina up to $1.5 \mathrm{~cm}$, width $0.8 \mathrm{~cm}$. Margin entire, midvein strong, straight, higher venation fine, dense, often not visible. Leaves according to preservation - coriaceous.

Description. Buxus is a rare accessory element in the Mecsek flora. In the Tertiary of Hungary it appears for the first time in the Mecsek flora. In the Pliocene, Buxus pliocenica Saporta et Marion was confirmed also by cuticle analysis (Hably and Kvaček, 1997).

\section{Rosaceae}

\section{Rosa sp.}

Pl. 14, figs 4-6

Material. Magyaregregy: PBO 2002.610.1, 2007.5.2, 2013.201.2, 2018.308.2, Magyaregregy, Vágyom-völgy: PBO 2004.138.2.

Description. Leaflets up to $3 \mathrm{~cm}$ long, $2 \mathrm{~cm}$ wide, sometimes with very short petiole. Shape of lamina wide ovate to elliptic, slightly asymmetrical, base cordate or missing, apex acute. Margin toothed, teeth simple, apical 
side of teeth convex to straight, basal part convex, tooth apex acute. Sinuses between teeth angular. Venation craspedodromous. Midvein strong, secondaries slightly curved, running toward margin, ending in tooth apices. Distance between secondaries much larger in middle part of lamina than at apex and base. Between secondaries, weak tertiary venation runs perpendicular to secondaries.

Discussion. Rosa generally is a rare accessory element in the Miocene floras of Europe, similarly to the flora of the Mecsek Mts in which only a few leaflets belonging to this genus were found.

\section{cf. Prinsepia serra}

(Unger) Kovar-Eder et Kvaček

Pl. 14, figs 7-12

2004 Prinsepia serra (Unger) Kovar-Eder et Kvaček; Kovar-Eder et al., p. 72, pl. 13, figs 9-17.

Material. Magyaregregy: PBO 2002.608.1, 2002.609.1,2016.142.1,2016.143.2, 2016.292.1, 2016.306.2, 2017.83.2, 2018.369.1, Magyaregregy, Vágyom-völgy: PBO 2017.92.2, 2019.38.2.

Description. Simple leaves, length of lamina $2-4$, width $1.8-2.8 \mathrm{~cm}$. Lamina shape obovate, apex emarginate, base decurrent, margin densely, irregularly toothed along almost the
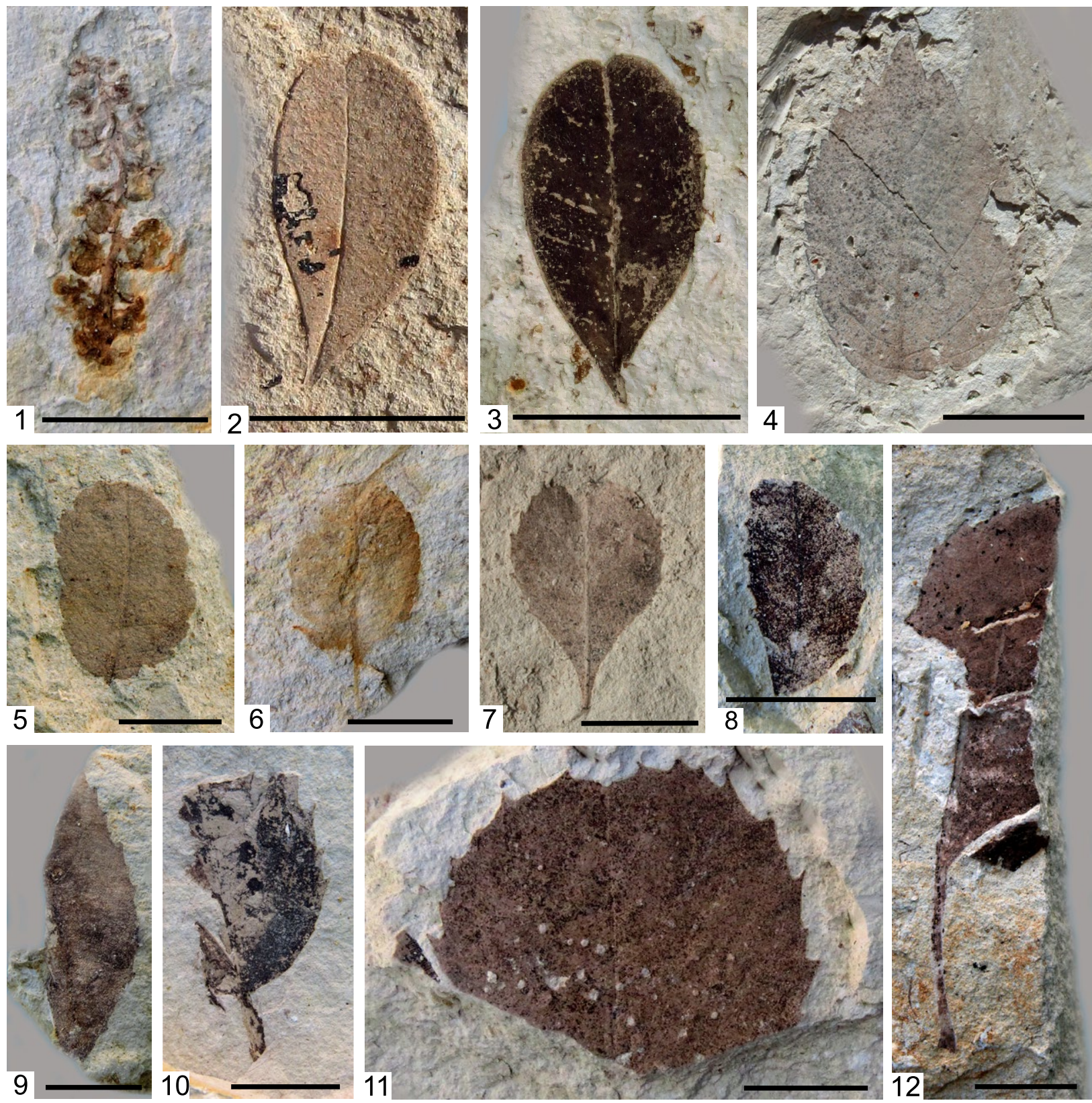

Plate 14. 1. Populus sp., catkin, PBO 2013.199.2; 2, 3. Buxus sp., leaf, 2. PBO 2002.604.2, 3. B PBO 2002.603.2; 4-6. Rosa sp., leaflet, 4. PBO 2002.610.1, 5. PBO 2004.138.2, 6. PBO 2013.201.2; 7-12. cf. Prinsepia serra (Unger) Kovar-Eder et Kvaček, leaf, 7. PBO 2002.608.1, 8. PBO 2017.83.2, 9. PBO 2017.92.2, 10. PBO 2016.306.2, 11. PBO 2002.609.1, 12. PBO 2019.38.2. Scale bar = $1 \mathrm{~cm}$ 
whole leaf length, teeth sharp. Venation semicraspedodromous.

Discussion. The species was described from Parschlug originally by Unger under various names. Recently, Kovar-Eder et al. (2004) revised the flora of Parschlug and described this species as Prinsepia serra. A comparable leaf remain was described by Unger (1867) as Celastrus oxyphyllus from Kymi and later was revised by Velitzelos et al. (2002) as ?Berberis. From Oeningen near Kesselstein, Heer (1859) described similar leaves as Ilex berberidifolia (Heer, 1859: 72, pl. 122, figs 12-18). Kolakovszki (1964) reported a comparable leaf as Pentapanax fimbriatum Kolakovski from the Pliocene flora of Kodor. The species is a rare accessory element in the flora of Magyaregregy. Its morphology displays xerophytic features suggesting dry climate conditions.

\section{Rosaceae gen. et sp. twig Pl. 15, fig. 1}

Material. Magyaregregy: PBO 2018.257.2.

Description. Length of twig $10.3 \mathrm{~cm}$, width $1.0 \mathrm{~cm}$. Prickles spaced $1.8-2.0 \mathrm{~cm}$ apart on stem. Length of prickles $0.2 \mathrm{~cm}$.

Discussion. The family Rosaceae is represented in the flora of Magyaregregy by leaves belonging to the genera Rosa and cf. Prinsepia. The stem with regularly spaced prickles probably belongs to this family. From Parschlug, Kovar-Eder et al. (2004: pl. 8, fig. 13) described a stem with thorns as "? Prinsepia sp." From Oregon, several stems are mentioned as rosaceous prickly stems, which are common in some assemblages of the Bridge Creek flora. Some of them, as evidenced by leaves attached to the stem, belong to Rubus, some others to Rosa species (Meyer and Manchester, 1997).

\section{Celastraceae gen. et sp.}

Pl. 15, fig. 2

Material. Magyaregregy: PBO 2002.612.2, 2016.151.2.

Description. Obovate simple leaves with petiole. Maximum length of petiole $1.2 \mathrm{~cm}$. Lamina length up to $7 \mathrm{~cm}$, width up to $2.4 \mathrm{~cm}$. Apex acute, base cuneate, venation semicraspedodromous, midvein strong, secondaries branching within margin, one of the branches terminates at margin in tooth apices. Margin toothed in upper two-thirds of lamina, margin entire in basal part. Teeth relatively small, regular, tooth apex obtuse, sinuses rounded.

Discussion. Based on leaf morphology, systematic identification at generic level is not possible. This leaf type with a few specimens was documented in Magyaregregy only from one locality. It was a rare accessory element in the flora.

Fabaceae

Leguminosae gen. et sp. leaflet

Pl. 15, figs 4-11

Material. Abaliget, Nyáras-völgy: PBO 2016.25.2-2016.27.1, Hetvehely, Kán: PBO 2017.5.1, 2017.6.1, Kisbattyán: PBO 2012.162.2, 2012.163.2, Kisbeszterce: PBO 2006.383.12006.396.1, 2012.108.1, 2012.114.2, 2012.137.1, Magyaregregy: PBO 2002.663.3-2002.759.4, 2006.773.1, 2007.127.2, 2016.131.1, 2016.305.1, 2017.16.1, 2017.17.1, 2017.60.2-2017.62.2, 2017.65.1-2017.67.1, 2017.115.3-2017.117.1, 2017.119.2, 2017.127.2, 2018.247.2-2018.250.1, 2018.253.2, 2018.295.1-2018.301.2, 2019.22.3, 2019.37.2, 2019.42.1, 2019.67.2, 2019.70.2, 2019.79.2, Magyaregregy, Almás-patak: PBO 2006.539.1, 2006.540.1, Magyaregregy, Farkasordító-árok: PBO 2006.486.12006.489.1, 2006.505.1, 2016.114.1, 2016.128.1, Magyaregregy, Leánykói-árok: PBO 2016.80.1, 2016.115.1-2016.121.1, Magyaregregy,Vágyomvölgy: PBO 2002.346.1-2002.347.1, 2002.365.2, 2004.145.2-2004.149.2, 2007.226.2-2007.229.1, 2017.90.2.

Description. Leaflets often with short petiole; length of petiole up to $0.4 \mathrm{~cm}$, shape of lamina ovate to wide ovate, symmetrical, length of lamina generally $1.8-2.6 \mathrm{~cm}$, rarely larger, width generally $0.8-1.5 \mathrm{~cm}$. Apex slightly emarginate, rarely obtuse or acute. Base rounded or obtuse, margin entire. Midvein strong, secondaries generally fine, forming loops near margin. Venation camptodromous, brochidodromous.

Discussion. Leaflets belonging to this family are very frequent in the Mecsek flora. In some localities they are dominant, and they occur in both the fish-scale marl and the volcanic layers. Since several pods have also been recorded in the flora, members of Fabaceae 
seem to have been dominant elements in the Miocene flora of the Mecsek Mts.

\section{Acacia parschlugiana Unger}

Pl. 15, fig. 3

1850a Acacia parschlugiana Unger; Unger, p. 494 pro parte.

1852 Comptonia laciniata Unger; Unger, p. 33, pl. 16, fig. 8 .
1864 Acacia parschlugiana Unger; Unger, p. 35, pro parte, pl. 11, fig. 20.

1994 "Acacia" parschlugiana Unger; Hably, p. 23, pl. 19, fig. 6 .

2004 "Acacia parschlugiana" Unger; Kovar-Eder et al., p. 75, pl. 9, fig. 12 .

Material. Magyaregregy: PBO 2007.23.1.

Description. Compound leaf remain with 14 pairs of leaflets. Whole leaf fragment $3.1 \mathrm{~cm}$
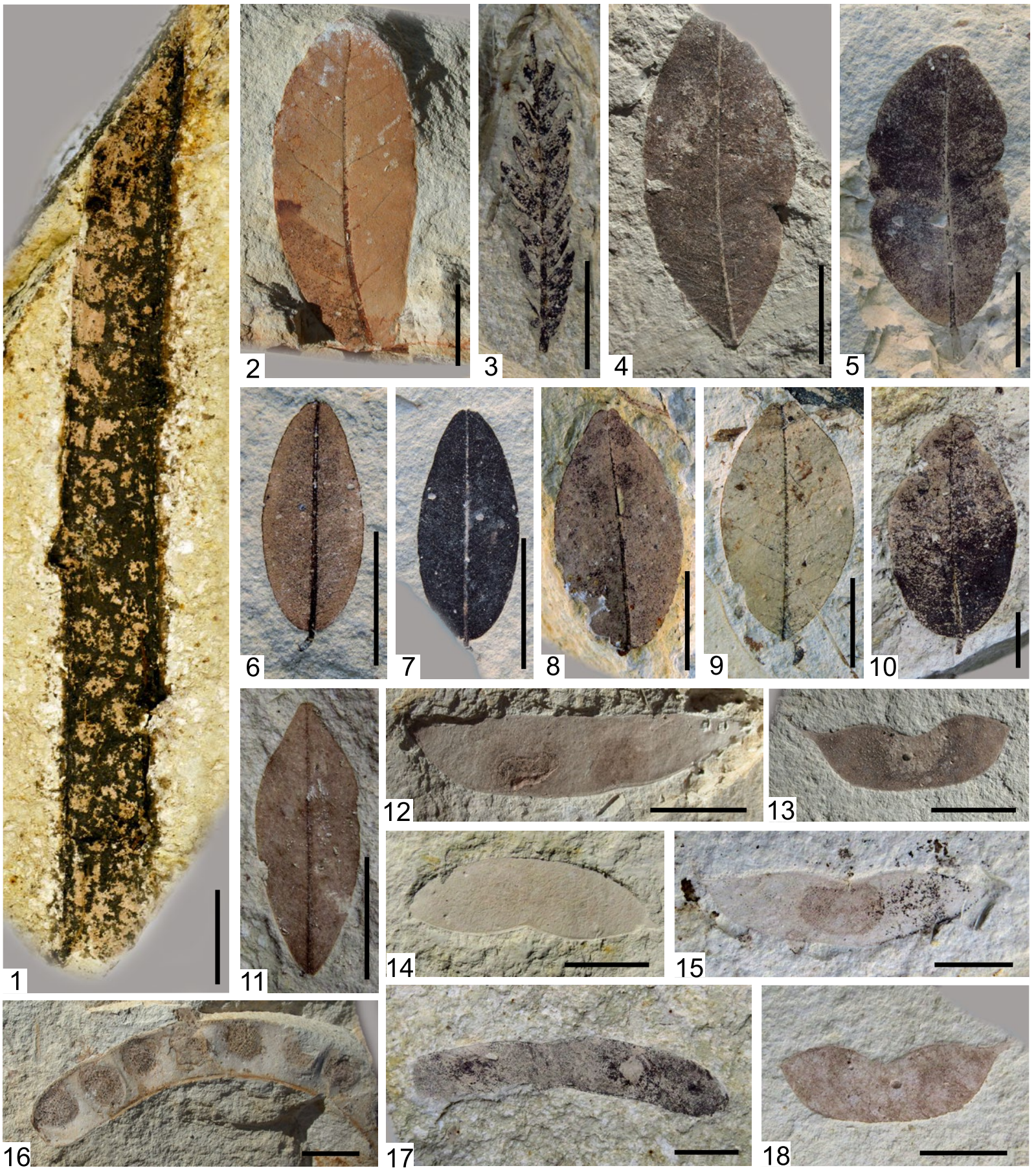

Plate 15. 1. Rosaceae gen. et sp., twig, PBO 2018.257.2; 2. Celastraceae gen. et sp., leaf, PBO 2002.612.2; 3. Acacia parschlugiana Unger, leaf, PBO 2007.23.1; 4-11. Leguminosae gen. et sp., leaflet, 4. PBO 2002.701.2, 5. PBO 2002.683.1, 6. PBO 2002.729.2, 7. PBO 2002.729.2. counterpart, 8. PBO 2002.670.1, 9. PBO 2002.696.1, 10. PBO 2007.77.2, 11. PBO 2007.127.2; 12-15, 17, 18. Leguminocarpum mecsekense Andreánszky, 12. PBO 2000.321.1, 13. PBO 2000.399.2, 14. PBO 2000.317.2, 15. PBO 2000.319.2, 17. PBO 2000.479.2, 18. PBO 2000.399.2; 16. Leguminosites palaeogaeus (Unger) Kovar-Eder et Kvaček PBO 2000.459.2. Scale bar $=1 \mathrm{~cm}$ 
long. Leaflets $0.35-0.6 \mathrm{~cm}$ long, $0.1-0.15 \mathrm{~cm}$ wide. Leaflets longest at middle part of leaf. Shape of leaflets narrow elliptic to narrow ovate, apex rounded, base slightly asymmetrical, rounded. Leaflet margin entire.

Discussion. Similar leaves were described from the Miocene flora of Parschlug by Unger (1850a), later by Kovar-Eder et al. (2004). This type of fabaceous leaf is rare in Magyaregregy but other leaflets belonging to the Fabaceae frequently occur. In Magyaregregy there are various types of pods, but leaves and fruits are not associated.

\section{Leguminocarpum mecsekense Andreánszky}

$$
\text { Pl. 15, figs 12-15, 17, } 18
$$

1955 Leguminocarpum mecsekense Andreánszky; Andreánszky, p. 15, pl. 1, fig. 3.

1992b Leguminocarpon type IV.; Hably, p. 175, pl. 3, figs $4-6$, pl. 4, figs 1-6, text-fig. 2 d.

Material. Magyaregregy: PBO 2000.317.22000.322.1,2000.399.2, 2000.447.1,2000.448.2, 2000.479.2, 2000.640.2, 2006.500.1, 2006.501.1, Magyaregregy, Vágyom-völgy: PBO 2002.348.1.

Description. Pods up to $5 \mathrm{~cm}$ long, 0.7$1.0 \mathrm{~cm}$ wide. Apex and base acute. Two ovate seeds oriented parallel to fruit axis. Width of seeds up to $0.7 \mathrm{~cm}$, length up to $1.1 \mathrm{~cm}$. Distance between seeds up to $1.7 \mathrm{~cm}$. Shape of fruit elongated, slightly curved. Pod incised by seed. Venation forms polygonal network on entire surface of pod. Veins primarily thin, thicker veins without preferred orientation.

Discussion. The fruit type was figured and later described by Andreánszky (1955) as Leguminocarpum mecsekense. Andreánszky identified these fruits as Dalbergia pods and mentioned two types of pods: a common type with one seed, and another with two seeds (Andreánszky found only one specimen of the latter). Later, several specimens with two seeds were collected by Andreánszky and also by Pálfalvy. Pálfalvy $(1964,1965)$ refers to it as Dalbergia mecsekensis, without any description. I and my colleagues found several specimens belonging to $L$. mecsekense at Magyaregregy. In view of the large collection, it seems that this species was a characteristic but not dominant element of the flora. Pods with one seed are much more frequent than pods with two seeds. In a review of the Tertiary legumes of Hungary (Hably, 1992b) this species is given as Leguminocarpon type IV. Similar pods were described from Parschlug (Kovar-Eder et al., 2004) as Leguminosites parschlugianus (Unger) Kovar-Eder et Kvaček, but they differ in shape and in the number of seeds: L. parschlugianus is asymmetrical and has 2 or 3 seeds.

\section{Leguminosites palaeogaeus (Unger) Kovar-Eder et Kvaček Pl. 15, fig. 16}

1850a Mimosites palaeogaea Unger; Unger, p. 494.

1864 Mimosa palaeogaea Unger; Unger, p. 34, pl. 11, fig. 12.

1992b Leguminocarpon type VI., Hably, p. 182, pl. 3, fig. 3, text-fig. 2 f.

2004 Leguminosites palaeogaeus (Unger) Kovar-Eder et Kvaček; Kovar-Eder et al., p. 74, pl. 9, fig. 1.

Material. Magyaregregy: PBO 2000.459.2, Abaliget, Kiskô-hegy: PBO 2017.34.1, Magyaregregy, Leánykói-árok: PBO 2016.78.1-2016.79.1, BK-5419.

Description. Large, strongly or slightly curved pods. Length up to $9.2 \mathrm{~cm}$, width up to $1.4 \mathrm{~cm}$. Apex obtuse or missing, base missing. Seeds rounded, up to $1 \mathrm{~cm}$ in diameter, closely spaced, filling pod from dorsal to ventral suture. Dorsal and ventral sutures thick through the whole length of the pod.

Discussion. In a review of the legumes of the Tertiary of Hungary (Hably, 1992b), this legume form was described as Leguminocarpon type VI. from Magyaregregy. In the Hungarian Tertiary, the Egerian floras are especially rich in pods (Hably, 1992b; Selmeczi and Hably, 2009), but these differ from the type occurring in Magyaregregy. From Parschlug, Kovar-Eder et al. (2004) described Leguminosites palaeogaeus as a new combination. Although this pod type is rare in the flora, there are several pods and leaflets of Fabaceae, suggesting that this family was an important and dominant element of the Miocene flora of the Mecsek Mts.

\section{Podocarpium podocarpum}

(A. Braun) Herendeen

Pl. 16, figs 1-12

1850c Dalbergia podocarpa Unger; Unger, p. 185, pl. 61, figs 1-14.

1859 Podogonium knorrii Heer; Heer, p. 114, 199, pl. 134, figs 22-26, pl. 135, pl. 136, figs 1-9.

1963 Podogonium oehningense (Koenig) Kirchheimer; 
Rüffle, p. 205, pl. 9, figs 1-14, pl. 22, figs 1-7, pl. 23, figs 2-4, text-figs 21-25.

1992a Podogonium knorrii (A. Braun) Heer; Herendeen, p. 4, figs 1-5.

1992b Podocarpim podocarpum (A. Braun) Herendeen; Herendeen, p. 732.

1995 Podogonium knorrii (A. Braun) Heer; Erdei, p. 15, figs 10, 11

2004 Podocarpium podocarpum (A. Braun) Herendeen; Kovar-Eder et al., p. 74, Pl. 9, figs 8-11.

2010 Podocarpium podocarpum (A. Braun) Herendeen; Hably et al., p. 13, fig. 10.
2017 Podocarpium podocarpum (A. Braun) Herendeen; Hably and Meller, p. 139, pl. 2, figs 4-6, 13.

Material (pods). Abaliget, Kiskó-hegy: PBO 2016.160.2, Magyaregregy: PBO 2000.276.1, 2000.298.1-2000.316.2, 2000.419.2, 2000.420.2, 2000.443.2-2000.446.1, 2001.746.2，2006.469.1, 2006.565.2, 2017.18.1, 2017.19.2, Magyaregregy, Kisréti-árok: PBO 2016.125.1.

M a t e r i al (leaflets). Abaliget, Kiskő-hegy: PBO 2016.163.1, 2017.29.1, Abaliget, Nyáras-völgy:
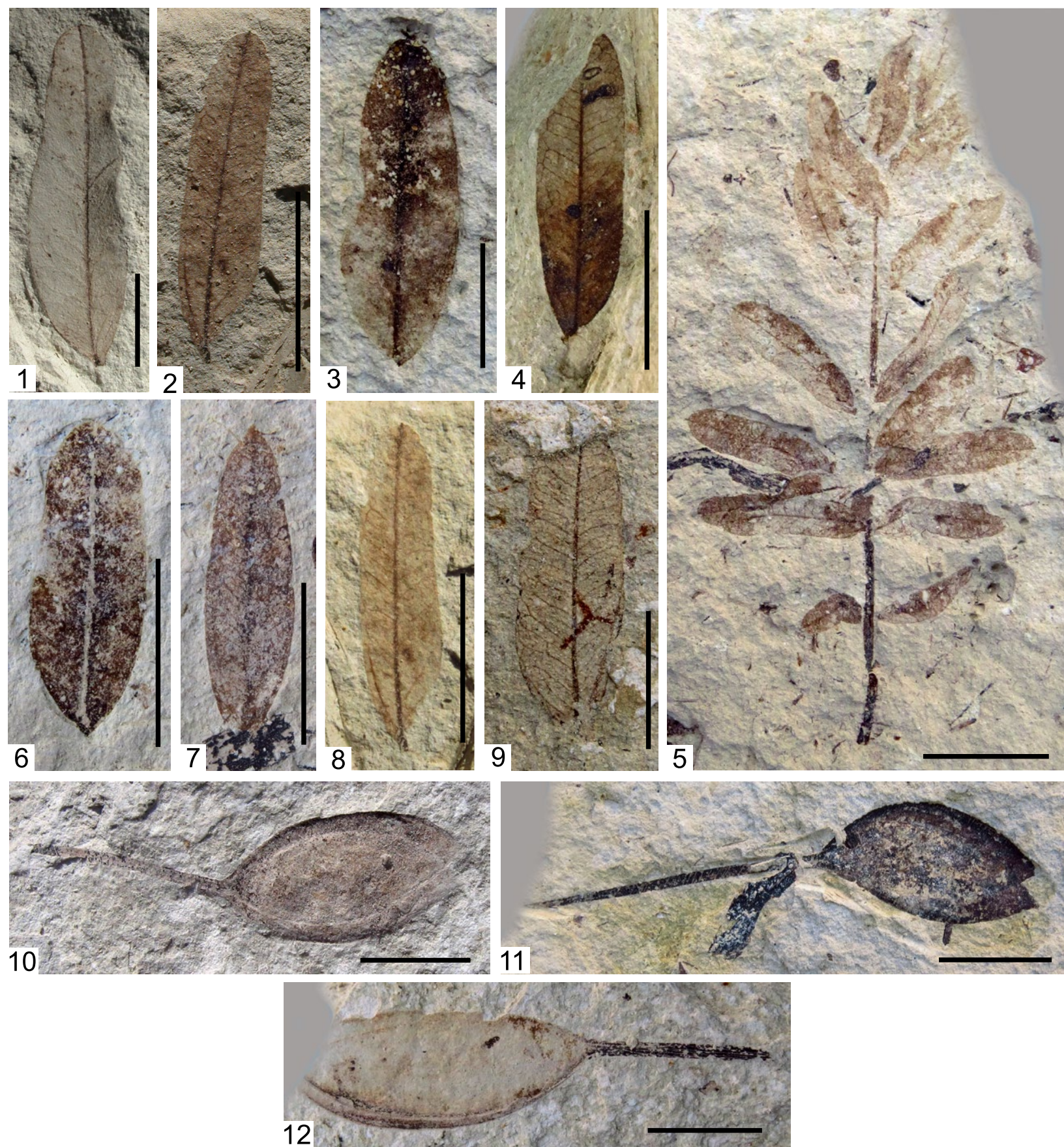

Plate 16. 1-12. Podocarpium podocarpum (A. Braun) Herendeen, 1. leaflet, PBO 2000.304.1, 2. leaflet, PBO 2000.313.1, 3. leaflet, PBO 2004.892.1, 4. leaflet, PBO 2007.35.1, 5. leaf, PBO 2006.567.2, 6. leaflet, PBO 2001.747.2, 7. leaflet, PBO 2000.305.2, 8. leaflet, PBO 2000.313.1, 9. leaflet, PBO 2000.311.2, 10. pod, PBO 2000.298.1, 11. pod, PBO 2001.746.2, 12. pod, PBO 2006.565.2. Scale bar $=1 \mathrm{~cm}$ 
PBO: 2016.34.1, 2016.35.1, Magyaregregy: PBO 2000.276.1, 2000.304.1, 2000.494.1, 2000.495.1, 2001.745.1-2001.750.2, 2001.933.2, 2002.500.2, 2004.887.2-2004.893.1, 2006.470.1, 2006.471.1, 2006.518.1, 2006.566.2-2006.569.1, 2006.768.2, 2007.34.2, 2007.35.1, 2007.100.2, 2007.112.1, 2007.121.1, 2017.77.1, 2017.138.1, 2018.256.2, 2019.43.1, 2019.46.1, 2019.56.1, Magyaregregy, Farkasordító-árok: PBO 2006.506.1, Magyaregregy, Vágyom-völgy: 2004.143.1, 2004.144.2, 2017.46.2.

Description. One compound leaf and several leaflets. Rachis of whole leaf $5 \mathrm{~cm}$ long. Leaflets 8 pairs, leaflets up to $3.5 \mathrm{~cm}$ long and $0.9 \mathrm{~cm}$ wide. Lamina shape elongated oval to lanceolate. Base slightly asymmetrical, rounded (obtuse) to acute. Apex rounded, rarely emarginate or acute. Margin entire. Venation brochidodromous, camptodromous. Midvein relatively strong, secondaries fine and dense. At base at one side of lamina, strong basal vein arises at acute angle. Pods with up to $2.5 \mathrm{~cm}$ long petiole. Pods up to $2.7 \mathrm{~cm}$ long, $1.1 \mathrm{~cm}$ wide, shape of pod ovate, elongated ovate, with one seed.

Discussion. This is the earliest occurrence of the species in the Tertiary flora of Hungary. During the Sarmatian (late Middle Miocene) it was accompanied mainly by Quercus kubinyii, Zelkova zelkovifolia and "Parrotia" pristina, which are all characteristic and dominant taxa of Sarmatian floras. These species are shared by nearly all Sarmatian floras (Hably, 1992b; Erdei and Hír, 2002). During the Pannonian, $P$. podocarpum disappeared from the Pannonian Basin (Hably, 1992b) and was not recorded in the surrounding area after the Sarmatian. One of its latest occurrences is known from the late Sarmatian flora of Gratkorn (Hably and Meller, 2017). Podocarpium podocarpum mostly inhabited gallery forests under subtropical and warm-temperate climate (KovarEder et al., 2004). That is suggested as well by the Gratkorn assemblage, where Podocarpium seems to have been a member of an edaphic association occupying habitats close to water. On the other hand, during the Sarmatian it was dominant in volcanic floras.

\section{cf. Gleditsia sp.}

Pl. 17, figs $1-5$

1997 cf. Gleditsia sp.; Hably and Kvaček, p. 41, textfig. 28, pl. 18, figs 97, 98, pl. 19, figs 102-104. 1850a Evonymus latoniae Unger; Unger, p. 460.

1864 Evonymus latoniae Unger; Unger, p. 11, pl. 2, fig. 25.

2004 "Evonymus" latoniae Unger; Kovar-Eder et al., p. 85, pl. 12, figs 3-5.

Material. Magyaregregy: PBO 2002.600.3, 2016.149.1, 2016.150.2, 2017.111.2-2017.115.3, 2017.127, 2017.134.2, 2017.136.1, 2018.236.1, 2018.237.1-2018.239.1， 2019.51.2， 2019.90.2, Magyaregregy, Vágyom-völgy: PBO 2018.371.3, 2019.65.2.

Description. Shape of leaflets ovate, moderately or slightly asymmetrical. Lamina length $4.2-7.8 \mathrm{~cm}$, width $1.3-2.5 \mathrm{~cm}$. Base acute, apex attenuate, final part of apex obtuse. Margin serrate, teeth small, often hooked, some teeth very small and obtuse. Teeth absent at apical and basal part of margin. Midvein strong, slightly curved. Secondaries weak, dense, ending in tooth apices. Higher venation barely visible.

Discussion. Leaves were described as cf. Gleditsia sp. in the Pliocene flora of Gérce (Hably and Kvaček, 1997). Similar leaves were also mentioned from the flora of Parschlug by Kovar-Eder et al. (2004). However, the leaf lamina is not so lanceolate and the teeth of these leaves are not as serrate (acuminate) but rather slightly rounded, especially based on the specimen figured by Unger (1864: pl. 2, fig. 25). However, the other leaf figured in the revision of the Parschlug flora (Kovar-Eder et al., 2004: pl. 12, fig. 4) shows morphology similar to that of the leaf from Magyaregregy, as does the leaf mentioned by Unger (1864) from Radoboj as Prinos radobojanus (Unger, 1864: p. 15, pl. 3, fig. 36). The leaves mentioned from Parschlug as Evonymus latoniae and from Radoboj as Prinos radobojanus presumably belong to the same species. Since the taxonomic names established by Unger do not indicate real botanical affinities, the leaves are assigned to cf. Gleditsia sp.

\section{Thymelaeaceae}

\section{Daphne oeningensis}

(A. Braun) emend. Weyland

Pl. 17, figs 6-10

1851 Daphne oeningensis A. Braun in Sitzenberger; Sitzenberger, p. 8.

1866 Ledum limnophyllum Unger; Unger, p. 40, pl. 12, figs 24, 25?, 26.

1954 Daphne; Pimenova, p. 89, fig. 82. 

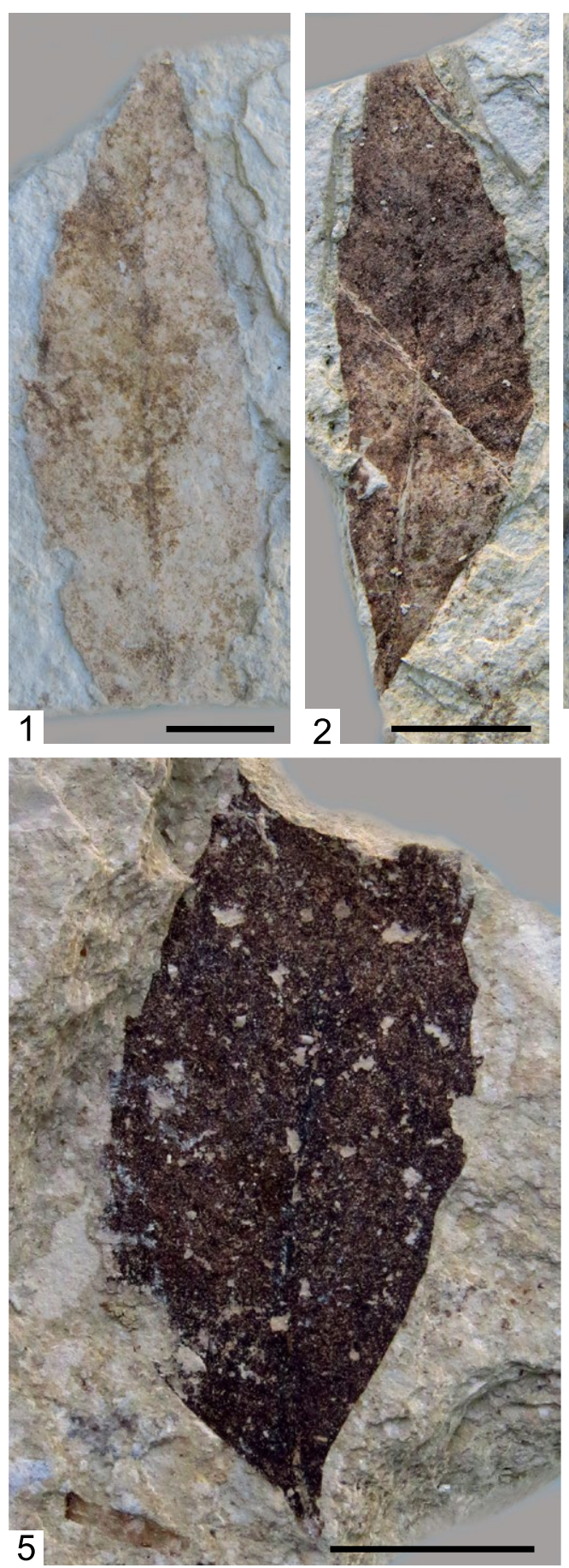
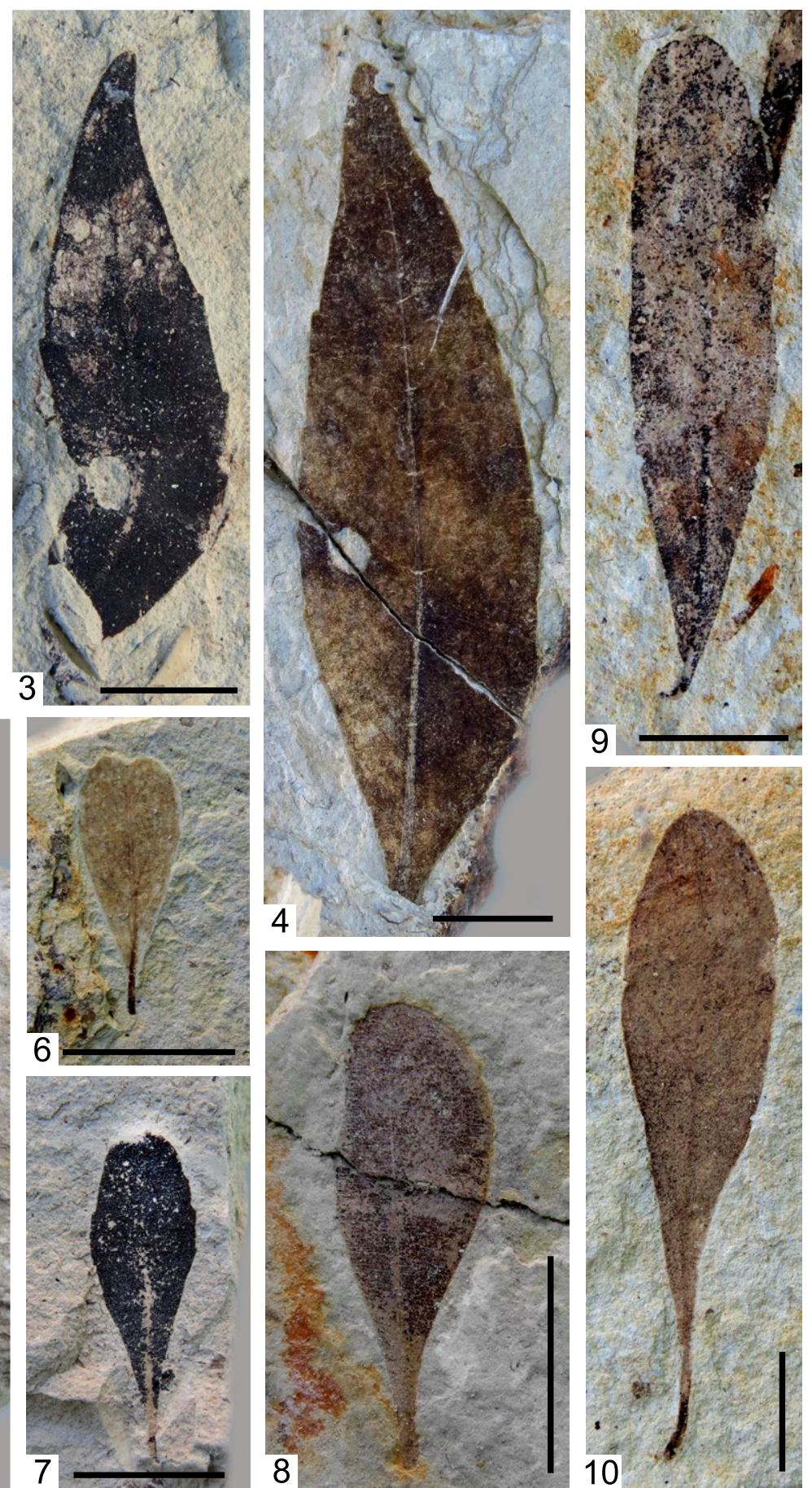

Plate 17. 1-5. cf. Gleditsia sp., leaflet, 1. PBO 2016.150.2, 2. PBO 2016.149.1, 3. PBO 2017.107.2, 4. PBO 2018.371.3, 5. PBO 2002.600.2; 6-10. Daphne oeningensis (A. Braun) emend. Weyland, leaf, 6. PBO 2017.123.1, 7. PBO2017.124.1, 8. PBO 2017.126.1, 9. PBO 2017.148.2, 10. PBO 2017.149.2. Scale bar $=1 \mathrm{~cm}$

1965 Daphne limnophylla (Unger) Baikovskaja; Kristofovich and Baikovskaja, p. 111, pl. 32, figs 3-5.

1980 Daphne oeningensis A. Braun; Zastawniak, p. 74, figs 11:7, 7a.

1985a Daphne oeningensis A. Braun emend. Weyland; Hably, p. 114, pl. 32, figs 1-4, text-fig. 23.

Material. Magyaregregy: PBO 2017.122.22017.126.1, 2018.228.1-2018.232.1, 2018.322.2, 2018.323.2, Magyaregregy-Vágyom-völgy: PBO 2017.148.2, 2017.149.2.
Description. Simple petiolate leaves, petiole up to $1.1 \mathrm{~cm}$. Shape of lamina obovate, lamina length $1.2-4.1 \mathrm{~cm}$, width $0.7-1.3 \mathrm{~cm}$. Apex rounded, base cuneate to decurrent, margin entire, midvein strong, straight, higher venation barely observable.

Discussion. Similar leaves were described from Hungary from the early Miocene flora of Ipolytarnóc (Hably, 1985a). From Europe it 
was recorded from Miocene floras (Weyland, 1938; Zastawniak, 1980).

\section{Rhamnaceae}

\section{Ziziphus paradisiaca (Unger) Heer}

Pl. 18, figs 1-7, pl. 19, figs $1-7$, pl. 20, figs 1,2

1845b Daphnogene paradisiaca Unger; Unger, p. 227. 1850b Daphnogene paradisiaca Unger; Unger, p. 427.

1850a Daphnogene paradisiaca Unger; Unger, p. (169) 39 , pl. 17(38), figs 1-7.

1850a Daphnogene melastomacea Unger; Unger, p. 38(168), pl. 16(37), fig. 12, pl. 17(38), figs $1-5$.

1850a Daphnogene relicta Unger; Unger, p. 38(168), pl. 18(39), fig. 6 .

1853 Ceanothus zizyphoides Unger; Ettingshausen, p. 76 , pl. 25, fig. 26, 36, 38 .

1859 Daphnogene paradisiaca Unger; Heer, p. 74, 291.

1859 Zizyphus paradisiacus Unger; Heer, p. 377.

1867 Cinnamomum rossmässleri Heer; Unger, p. 55, pl. 7, fig. 32 .

1874 Zizyphus paradisiacus Unger; Schimper, p. 219.

1883 Zizyphus integrifolius Pilar; Pilar, p. 106. pl. 14, figs 22, 23.

1883 Zizyphus paradisiacus Unger; Pilar, p. 107. pl. 14, figs $14-18,19$.

1943 Zizyphus zizyphoides (Unger) Weyland; Weyland, p. 113.

1956 Zizyphus paradisiacus Unger; Pantic, p. 272, 273, pl. 14, figs $1,2$.

1962 Zizyphus zizyphoides (Unger) Weyland; Givulescu, p. 160, 161, text-figs 162, 163, 255.

1971 Zizyphus ungeri Heer; Fernandez Marron, p. 101, 102, pl. 7, fig. 7 .

1996 Ziziphus paradisiaca (Unger) Heer; Knobloch and Kvaček, p. 61, pl. 16, figs 1, 2, pl. 17, fig. 8, pl. 19, fig. 2.

1996 Ziziphus paradisiaca (Unger) Heer; Bůžek et al., p. 37, pl. 21, figs 6,7 .

Material. Kisbattyán: PBO 95.409.1, 2012.1541-2012.156.2, Kisbeszterce: PBO 99.290.2, 2006.401.1, 2006.402.1, 2012.116.1, 2012.120.1, 2012.124.2, 2012.126.2, 2012.129.1, 2012.130.1, 2019.1.2, Magyaregregy: PBO 99.218.1-99.285.1, 99.424.2-99.485.2, 2000.259.2-2000.280.1, 2000.390.1-2000.393.2, 2000.421.2-2000.429.2, 2000.496.1-2000.499.2, 2001.655.2-2001.658.2, 2001.767.2, 2001.934.3, 2001.935.1, 2002.467.2-2002.470.2, 2002.477.2, 2002.626.1-2002.631.1, 2003.252.1, 2003.500.2, 2006.403.1-2006.410.1, 2006.509.1-2006.511.2, 2006.560.2, 2007.561.2, 2006.761.1-2006.767.2, 2006.776.1, 2007.18.2-2007.21.1, 2007.85.22007.91.2, 2013.260.1, 2015.457.1, 2015.459.1, 2015.460.1, 2015.462.1, 2015.463.1, 2015.477.1,
2015.486.1, 2015.526.1, 2016.133.1, 2016.135.1, 2017.20.2, 2017.76.1, 2018.251.2, 2018.310.2, 2018.370.2, 2019.19.1, 2019.52.1, 2019.58.2, Magyaregregy, Almás-patak: PBO 2015.467.1, 2015.472.1, Magyaregregy, Farkasordító-árok: PBO 2006.473.1-2006.477.1, 2006.483.1, 2006.484.1, 2015.437.1, 2015.438.1, 2015.440.1, 2015.446.1-2015.452.1, 2015.458.1, 2015.461.1, 2015.464.1-2015.466.1, 2015.468.1-2015.481.1, 2015.483.1-2015.485.1, 2015.487.1, 2015.525.1, 2015.527.1, 2015.535.1-2015.538.1, 2016.40.1, 2016.112.1, Magyaregregy, Leánykói-árok: PBO 2015.439.1， 2015.441.1-2015.445.1, 2015.453.1-2015.456.1, 2016.41.1-2016.69.1, Magyaregregy,Vágyom-völgy: PBO 2002.336.12002.345.1, 2002.359.1, 2002.360.2, 2002.369.22002.371.1, 2004.93.2-2004.107.2, 2007.231.2, 2017.48.1, 2017.49.1, 2017.51.1, 2019.5.2.

Description. Simple leaves up to $8 \mathrm{~cm}$ long and up to $5 \mathrm{~cm}$ wide. Petiole up to $2 \mathrm{~cm}$ long. Shape of lamina ovate to elliptic. Apex acute, base acute to cuneate, in some cases asymmetrical. Margin entire to serrate, always entire at basal part of leaf, whole margin often entire, apical part of margin serrate in some cases. Tooth apex obtuse, apical and basal sides of teeth convex, apical side shorter than basal side. Sinuses rounded. Leaves trinerved, venation basal, eucamptodromous. Midvein and two basal veins strong. Basal veins depart from petiole and run parallel with margin, closer to margin than to midvein. Secondaries not visible, tertiary veins arise from midvein perpendicular to midvein and basal veins. Marginal tertiary veins run toward margin, forming marginal loops.

Discussion. Z. paradisiaca is a dominant element of the Miocene flora of the Mecsek Mts. It occurs both in the fish-scale marl layers and in the volcanic sediments; it is a characteristic species of all localities of the Miocene Mecsek flora. It occurs in Hungary only in these floras, as a dominant element. Another important region where this species is similarly dominant is Croatia, with localities including Radoboj (Heer, 1859), Sv. Nedelje, Sused, and Dolje at Vrabče (Croatia; Pilar, 1883). In Europe it is known as a rare accessory element at several other localities: Kumi (Greece; Unger, 1867), the Cheb Basin (Czech Republic) in bore holes (Bůžek et al., 1996), Mydlovary and Olešnik (Czech Republic; Knobloch and Kvaček, 1996). From the flora at Kumi it was described as Cinnamomum 
rossmässleri Heer (Unger, 1867: Taf. 7, fig. 32). Its occurences suggest that it is characteristic of Miocene floras, but it had a dominant role only in the Miocene of the Mecsek Mts and Croatia. Another Ziziphus species, Z. zizyphoides, is very common in the early Oligocene flora of Hungary; it is a dominant element of the floras of the Tard Clay Formation (Hably, 1979; Hably and Erdei, 2015). This species occured in several European early Oligocene floras such as Häring (Ettingshausen 1853: Taf. 25. figs 9-39 as Ceanothus ziziphoides Unger), Serbia (Mihajlovic, 1985) and Spain (Hably and Fernandez Marrón, 1998). The two species never accompanied each other. Z. zizyphoides is characteristic of the Paleogene, and $Z$. paradisiaca is characteristic of the early Miocene floras.

\section{Paliurus favonii}

Pl. 20, figs 3, 4

1847 Paliurus favonii Unger; Unger, p. 147, pl. 50, figs $7,8$.

1869 Paliurus favonii Unger; Ettingshausen, p. 39, pl. 50, figs 6, 7 .

1971 Paliurus tiliaefolius (Unger) Bůžek; Bůžek, p. 74, pl. 33, figs 4, 6, 7, 9-21.

2000 Paliurus favonii Unger; Kvaček and Hurnik, p. 18 , pl. 7, fig. 9 , text-fig. 5.6.

2004 Paliurus favonii Unger; Kovar-Eder et al., p. 76, pl. 11, figs $2,3,7$.
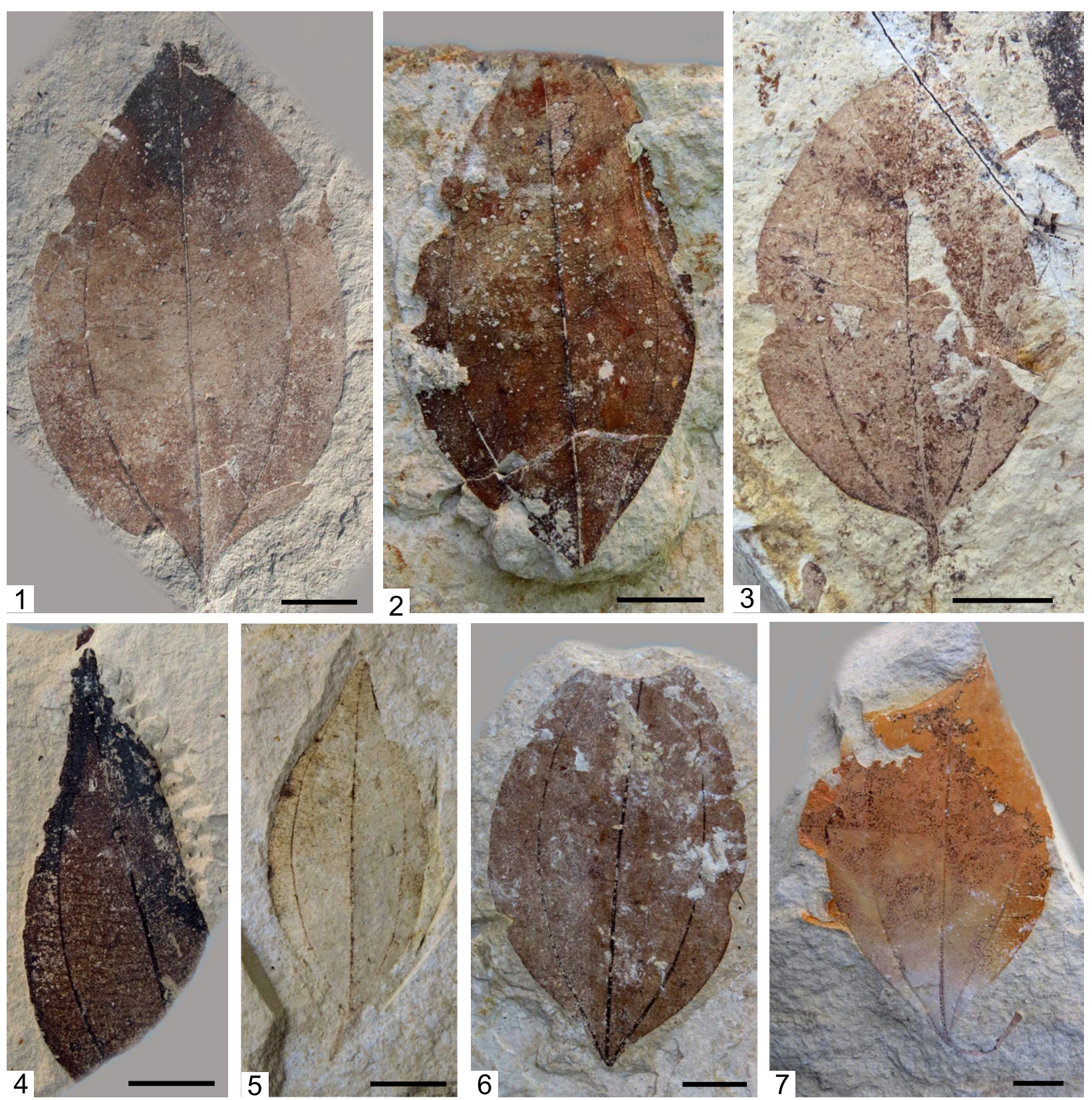

Plate 18. 1-7. Ziziphus paradisiaca (Unger) Heer, leaf, 1. PBO 2003.252.1, 2. PBO 2007.231.2, 3. PBO 2007.85.2, 4. PBO 2002.631.1, 5. PBO 99.242.1, 6. PBO 99.281.1, 7. PBO 99.474.2. Scale bar $=1 \mathrm{~cm}$ 
Material. Magyaregregy: PBO 2002.613.2, 2002.614.2.

Description. Trilocular fruits with circular wing, up to $1.4 \mathrm{~cm}$ in diameter; seed $0.45 \mathrm{~cm}$ in diameter.

Discussion. In several European floras the fruits are accompanied by leaf fossils: e.g. North-Bohemian Basin (Bůžek, 1971; Kvaček and Hurnik, 2000) and Parschlug (KovarEder et al., 2004). Leaf remains belonging to
Paliurus were not recorded in Magyaregregy. Winged fruits are also very rare, so they must have been transported from a longer distance.

\section{Berchemia multinervis (A. Braun) Heer}

Pl. 20, figs 5-7

1836 Rhamnus multinervis A. Braun; A. Braun in Buckland, p. 513.

1859 Berchemia multinervis (A. Braun) Heer; Heer p. 77, pl. 128, figs $9-18$.

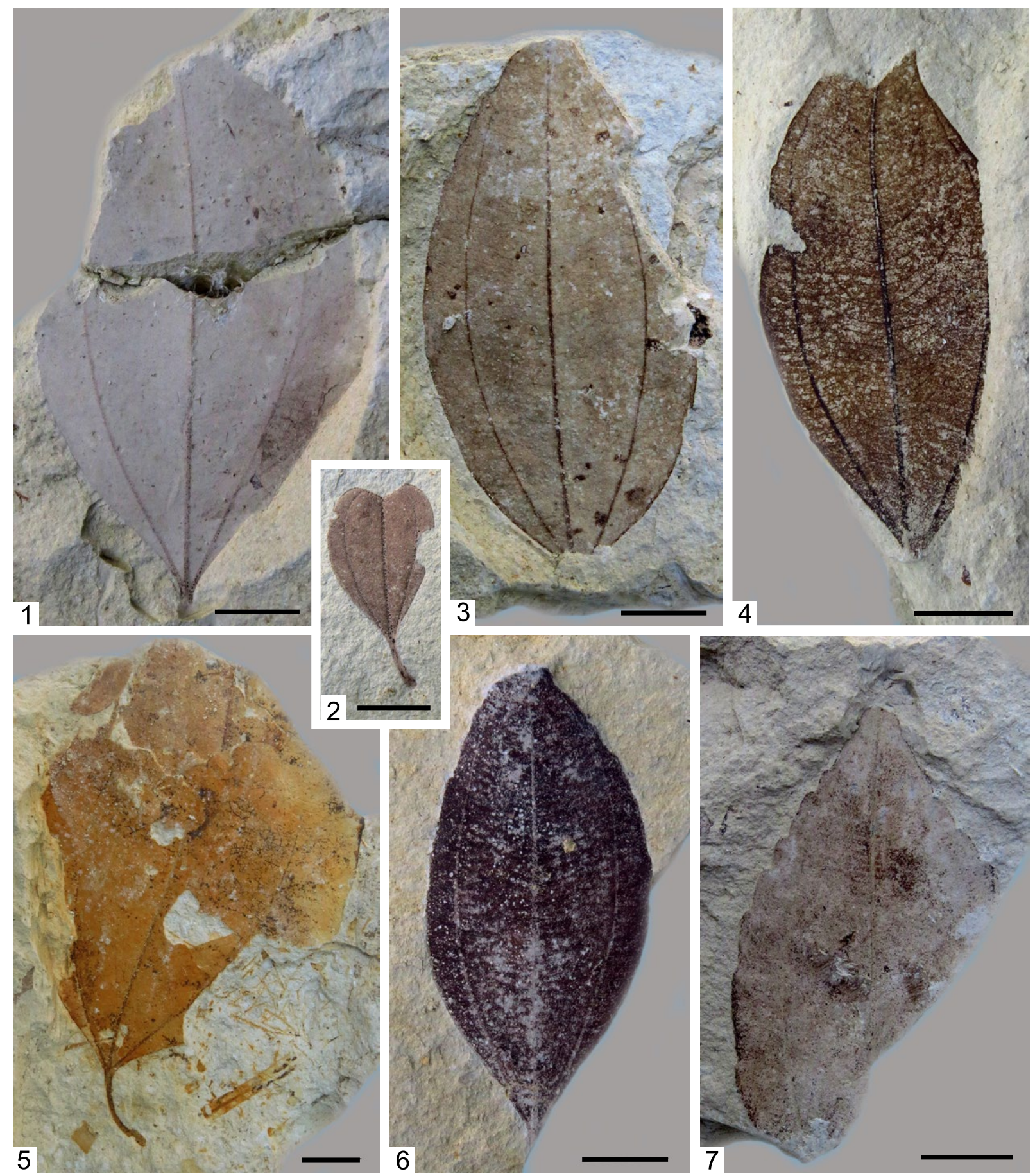

Plate 19. 1-7. Ziziphus paradisiaca (Unger) Heer, leaf, 1. PBO 99.481.2, 2. PBO 2000.392.2, 3. PBO 99.247.2, 4. PBO 2006.561.2, 5. PBO 2000.262.2, 6. PBO 99.277.2, 7. PBO 2000.268.1. Scale bar $=1 \mathrm{~cm}$ 

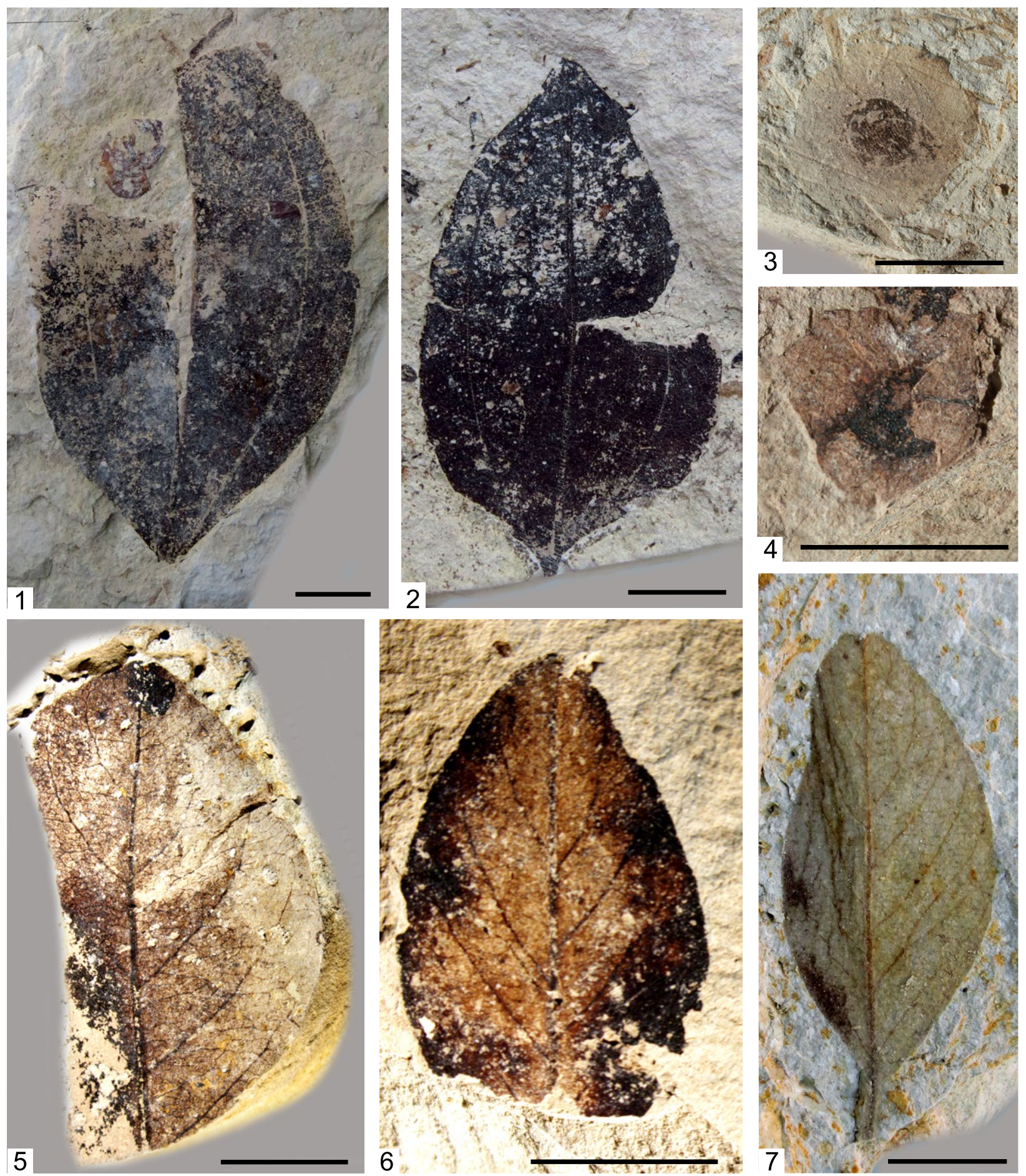

Plate 20. 1, 2. Ziziphus paradisiaca (Unger) Heer, leaf, 1. PBO 2000.263.2, 2. PBO 2007.86.2; 3, 4. Paliurus favonii Unger, fruit, 3. PBO 2002.613.2, 4. PBO 2002.614.2; 5-7. Berchemia multinervis (A. Braun) Heer, leaf, 5. PBO 2019.92.1, 6. PBO 2019.94.1, 7. PBO 2017.108.2. Scale bar $=1 \mathrm{~cm}$

1866 Quercus pseudo-laurus Ettingshausen; Ettingshausen, p. 60, pro parte, pl. 17, fig. 13.

1881 Berchemia multinervis (A. Braun) Heer; Velenovský, p. 42, pl. 4, figs 26, 27.

1891 Berchemia multinervis (A. Braun) Heer; Engelhardt, p. 188, pl. 12, figs 2, 19-28.

1971 Berchemia multinervis (A. Braun) Heer; Bůžek, p. 73, pl. 32, figs 12-15, pl. 33, figs 22, 23.

2000 Berchemia multinervis (A. Braun) Heer; Kvaček and Hurnik, p. 18, pl. 7, fig. 8, text-fig. 4.9, 5.5.
Material. Magyaregregy: PBO 2017.58.1, 2017.108.2, 2017.141.2, 2019.44.1, 2019.45.2, 2019.48.1, 2019.68.2, 2019.69.2, 2019.72.4, 2019.91.1, 2019.92.1, 2019.94.1.

Description. Simple petiolate leaves, shape of lamina ovate to elliptic. Petiole fragmentary, length $0.4 \mathrm{~cm}$, lamina up to $3.7 \mathrm{~cm}$ long, $1.7 \mathrm{~cm}$ wide. Apex missing, base acute, margin rarely 
or obscurely crenulate-serrulate. Midvein strong, straight, secondaries dense, diverging at acute angles, forming regular loops with each other near margin. Tertiary veins delicate, dense, running at \pm right angles to midrib.

Discussion. These elliptic rhamnoid leaves with dense venation are generally assigned to the genus Berchemia and are compared with $B$. scandens (Hill) K. Koch, a liana growing in swamps of the southeastern United States (Kvaček and Hurnik, 2000). It occurs as a rare accessory element in the Tertiary floras of Europe (Bůžek, 1971; Kvaček and Hurnik, 2000; Sakala, 2000). In the Miocene flora of the Mecsek Mts it is a rare accessory element.

\section{Sapindaceae}

\section{Acer sp. leaf}

Pl. 21, figs 1-3

Material. Magyaregregy: PBO 2000.281.1, 2002.493.2, 2002.495.1, 2007.75.2, 2007.119.1.

Description. Three-lobed palmate leaves of various sizes. Apex missing, base cuneate to rounded or missing. Venation actinodromous. Three primary veins diverge from base. Margin damaged, not visible.

Discussion. Some fragmentary leaves belong to the genus Acer. Unfortunately the fragments do not show specific characters. Acer is very common in the Miocene floras of Europe. In the Mecsek Mts only a few leaf remains were collected. Maples are frequent members of riparian forests.

\section{Acer div. sp. fructus}

Pl. 21, figs $4-9$

Material. Magyaregregy: PBO 2002.282.12002.286.2, 2000.394.1, 2002.494.2-2002.497.2, 2015.488.1-2015.491.1, 2015.534.1, 2016.123.1, 2016.298.2, 2017.17.1, cf. 2018.233.1, 2019.78.1, Magyaregregy, Leánykói-árok: PBO 2016.122.1, Magyaregregy, Vágyom-völgy: PBO 2002.353.2, 2004.124.2, 2004.125.2.

Description. Length of winged fruits up to $3 \mathrm{~cm}$. Shape of wings and seeds and venation varying between specimens.

Discussion. The samaras clearly belong to different species. At least four different groups can be distinguished. Classification of the samaras to species level requires preservation of the internal structure (Mai 1983, 1984; Kovar-Eder et al., 2004). These fruits are preserved only as impressions, and no internal structure is observable.

\section{Anacardiaceae}

\section{Cotinus sp.}

Pl. 21, fig. 10

Material. Magyaregregy: PBO 2017.120.2, 2017.121.2, Magyaregregy, Vágyom-völgy: PBO 2017.50.2.

Description. Simple petiolate leaf, whole length $8.2 \mathrm{~cm}$. Original length of lamina $\sim 7 \mathrm{~cm}$, width $3.5 \mathrm{~cm}$. Petiole $1.5 \mathrm{~cm}$ long, $0.4 \mathrm{~cm}$ wide. Shape of lamina roundish, broadly ovate, margin entire. Apex acuminate or missing, base decurrent. Venation brochidodromous. Midvein strong, secondaries thin, bifurcating near margin, forming loops.

Discussion. Similar leaves were mentioned from Parschlug (Kovar-Eder et al., 2004) as Cotinus (?) aizoon (Unger) Kovar-Eder et Kvaček. The specimen from Magyaregregy differs from $C$. aizoon in having a much wider petiole and more widely spaced secondaries. Cotinus was mentioned from the Pliocene flora of Gérce (Hably and Kvaček, 1997); the shape and venation of this specimen are very similar to those of the specimen from Magyaregregy.

\section{Rhus sp.}

Pl. 21, figs 11, 12

Material. Magyaregregy: PBO 2017.128.3, 2017.129.1.

Description. Trifoliate, alternate leaves. Base of leaflet decurrent, apex cuneate, margin serrate. Teeth irregular, tooth apices acute. Venation semicraspedodromous. Midvein strong, secondaries arise from midvein at irregular distances, forming loops near margin, and developing short veins ending in tooth apices.

Discussion. Comparable leaves are developed by the extant Rhus aromatica L., which is a deciduous woody shrub that can grow up to 2-4 $\mathrm{m}$ high. The species is distributed in Canada and the United States. It grows in uplands, open woods, fields, barrens and rocky cliffs. 


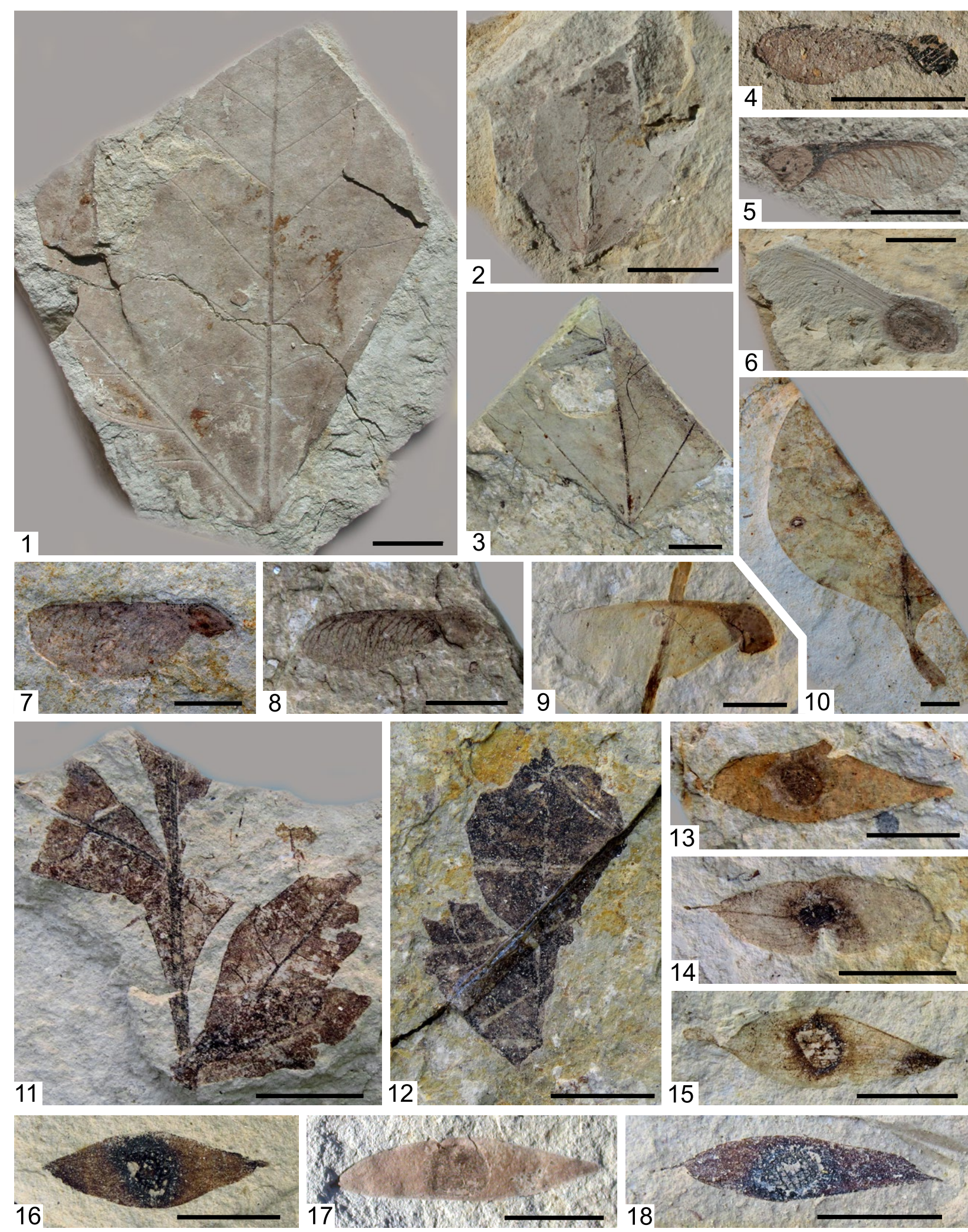

Plate 21. 1-9. Acer sp., 1. leaf, PBO 2002.493.2, 2. leaf, PBO 2002.495.1, 3. leaf, PBO 2002.281.1, 4. fruit, PBO 2002.494.2, 5. fruit, $\mathrm{PBO} 2000.282 .1$, 6. fruit, $\mathrm{PBO}$ 2002.497.2, 7. fruit, PBO 2004.125.2, 8. fruit, PBO 2000.286.2, 9. fruit, PBO 2000.285.2; 10. Cotinus sp., leaf, PBO 2017.50.2; 11, 12. Rhus sp., leaf, 11. PBO 2017.128.3, 12. PBO 2017.129.1; 13-18. Ailanthus confucii Unger, fruit, 13. PBO 99.414.1, 14. PBO 97.93.2, 15. PBO 97.63.2, 16. PBO 97.79.2, 17. PBO 99.415.2, 18. PBO 2001.751.2 


\section{Simaroubaceae}

\section{Ailanthus confucii Unger}

Pl. 21, figs $13-18$

1850c Ailanthus confucii Unger; Unger, p. 23, nom. nudum.

1859 Ailanthus Confuci Unger in Heer; Heer, p. 87, Pl. 127, fig. 36 .

1862 Rhopalospermites strangeaeformis Saporta; Saporta, p. 258, Pl. 8, fig. 7.

1866 Ailanthus confucii Unger; Unger, p. 54, Pl. 17, figs 6,7 .

1867 Ailanthus oxycarpa Saporta; Saporta, p. 111, Pl. 14, fig. 2.

1882 Ailanthus confucii Unger; Staub, p. 39, Pl. 4, fig. 2 (non 3).

1953 Ailanthus confucii Unger; Pálfalvy, p. 175 (non figured).

1959 Ailanthus confucii Unger; Andreánszky, p. 155, Pl. 67, fig. 2, text-fig. 181.

1964 Ailanthus confucii Unger; Pálfalvy, p. 187 (non figured).

2001 Ailanthus confucii Unger; Hably, p. 208, pl. 1, figs $1-10$.

2004 Ailanthus confucii Unger; Kovar-Eder et al., p. 82 , pl. 11, fig. 11 .

Material. Magyaregregy: PBO 97.63.297.97.1, 97.152.2, 97.153.1, 97.178.1-97.185.2, 99.413.2-99.416.2, 2000.199.1-2000.205.2, 2000.288.2,2000.401.1-2000.410.1,2000.458.1, 2001.748.3,2001.751.2,2001.761.2,2001.926.12001.928.2, 2002.500.2, 2002.540.2, 2006.564.2, 2006.739.2-2006.744.1, 2007.25.2-2007.29.2, 2007.40.2-2007.48.1, 2016.148.1, 2018.272.2, 2019.9.3, 2019.37.2, 2019.82.2, Magyaregregy, Leánykối-árok: PBO 2006.456.1-2006.459.1, 2016.65.1, 2016.70.1, 2016.70.1.

Description. Samaras elongated ovate, elliptic to obovate, $17-29 \mathrm{~mm}$ long, $4-8 \mathrm{~mm}$ wide. Apex and base acute. Single seed situated in \pm middle of fruit. Samaras not or slightly emarginate in seed region. Shape of seeds ovate, longitudinal axis of seed parallel with that of samara. Strong vein running from base up to seed; some fruits having another strong vein in middle of samara. Several thin veins run from seed towards apex and base, some of them anastomosing.

Discussion. A. confucii is a dominant element in the Mecsek flora, but in the other floras of Hungary only one specimen was found in the Sarmatian flora of Erdóbénye (Andreánszky, 1959). Ailanthus confucii is the most common species of the genus Ailanthus recorded in the European Miocene, including Radoboj, Aixen-Provence, Bois d'Asson and other localities. Fruits of $A$. confucii were documented in the early Miocene Cypris Shale flora (Bůžek et al., 1996), the early-middle Miocene Mydlovary Formation (Knobloch and Kvaček, 1996) and the Miocene flora of Parschlug (Kovar-Eder et al., 2004).

\section{Ailanthus mecsekensis Hably}

Pl. 22, figs 1-9

2001 Ailanthus mecsekensis Hably; Hably, p. 209, pl. 2, figs 1-6, pl. 3, fig. 8 .

Material. Kisbattyán: PBO cf. 2012.169.2, Magyaregregy: PBO 97.98.1, 97.100.2, 97.101.1, 97.102.1, 97.103.1, 97.104.2, 97.184.2, 97.185.2, 2000.204.1, 2000.416.2, 2000.457.1, 2000.484.2, 2002.461.2-2002.466.1, 2002.476.2, 2002.590.2, 2002.596.2, 2006.461.1, 2007.124.2, 2013.262.1, 2017.73.1, 2017.132.2, 2017.133.2, 2018.235.2, 2019.48.1, Magyaregregy, Leánykối-árok: PBO 2016.76.1, 2016.77.2, Magyaregregy, Vágyomvölgy: PBO 2017.144.2.

Description. Leaflets $6.5-10.5 \mathrm{~cm}$ long, $1.7-3.5 \mathrm{~cm}$ wide, with $0.7-2.0 \mathrm{~cm}$ long petiole. Lamina lanceolate, strongly asymmetrical, apex acute, base acute, asymmetrical, decurrent. Margin toothed, exceptionally undulate except for concave side of asymmetrical leaflets being entire-margined at basal part. Teeth obtuse to acute, irregular, coarser at convex basal part than at apical part. Venation semicraspedodromous, venation near entire or undulate margin brochidodromous. Midvein strong, slightly curved. Secondary veins thin, straight, barely visible, running nearly perpendicular or at obtuse angles to midvein.

Discussion. Fossil leaves of Ailanthus Desf. have frequently been mentioned in the literature. From the late Oligocene flora of Rott, Weyland (1938) described a leaf as A. ailanthifolia (Weber) Weyland ( $\equiv$ Rhus ailanthifolia C.O. Weber, 1852). From Socka, Quercus urophylla (Unger, 1850c) and Sapindus Pythii (Unger, 1860) were published. Saporta (1867) also published an asymmetrical leaf with a toothed margin from southeastern France and assigned it to A. oxycarpa Saporta, that is, under the same name as the fruit. From Kleinsaubernitz bei Bautzen (Germany), Walther (1999) described Ailanthus prescheri; from Parschlug, Kovar-Eder et al. (2004) 

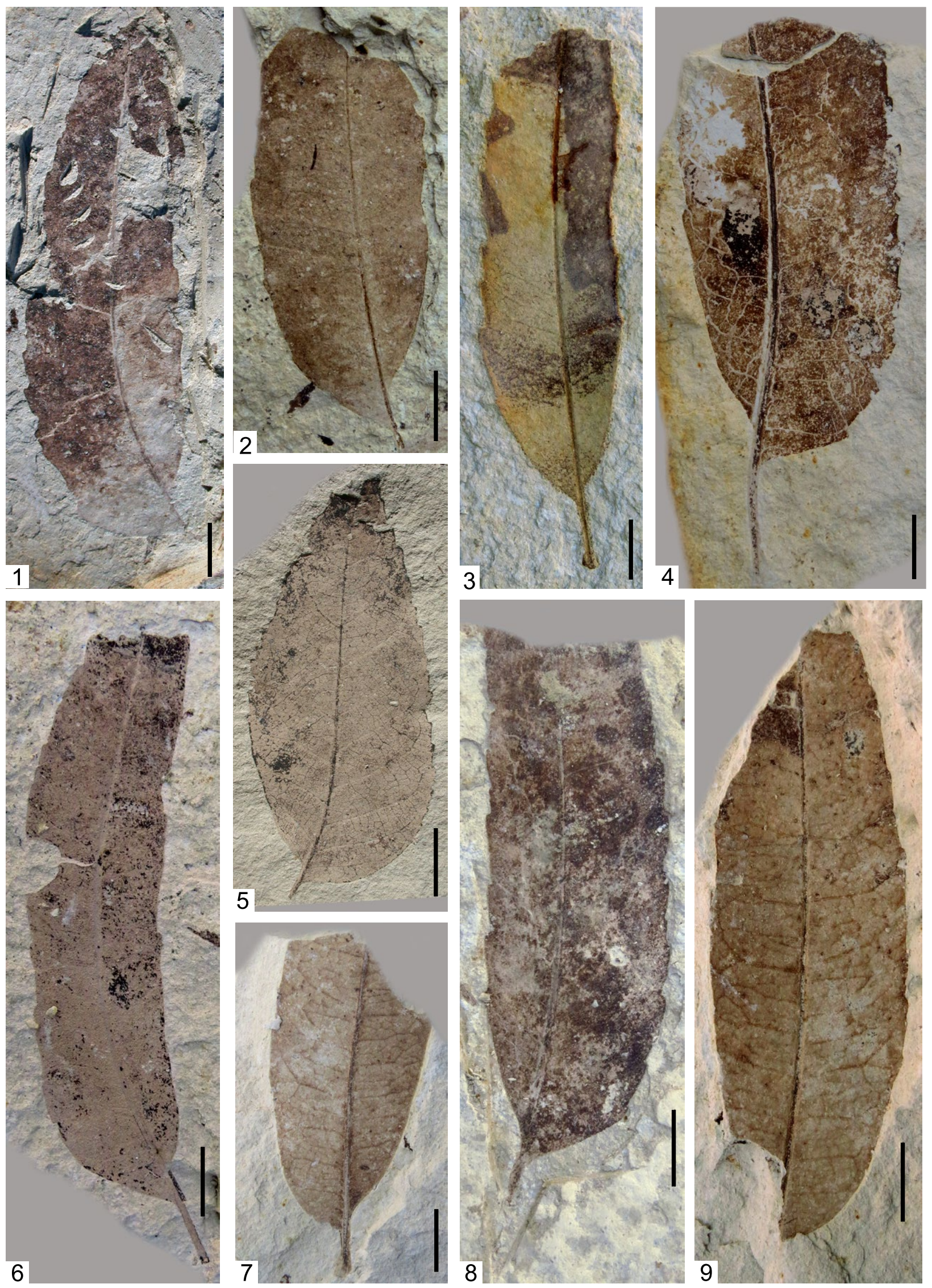

Plate 22. 1-9. Ailanthus mecsekensis Hably, leaflet, 1. PBO 97.104.2, 2. PBO 2007.124.2, 3. PBO 2002.463.2, 4. PBO 97.100.2, 5. $\mathrm{PBO}$ 2002.596.2, 6. PBO 97.185.2, 7. PBO 2002.590.2, 8. PBO 97.103.1, 9. PBO 2002.590.2. counterpart. Scale bar $=1 \mathrm{~cm}$ 
reported Ailanthus pythii (Unger) Kovar-Eder et Kvaček.

\section{Ebenaceae}

\section{Diospyros? microcalyx}

(Ettingshausen) Kvaček et Teodoridis

$$
\text { Pl. 23, figs 1-4 }
$$

1868 Macreightia microcalix Ettingshausen; Ettingshausen, p. 46, pl. 39, figs 3-5.

2001 Macreightia microcalyx Ettingshausen; Hably et al., p. 28, pl. 19. figs 3, 4, Pl. 20, fig. 3 .

2011 Diospyros? microcalyx (Ettingshausen) Kvaček et Teodoridis; Kvaček and Teodoridis, p. 104, pl. 13, figs $10-18$.

Material. Magyaregregy: PBO 2019.27.1, 2019.29.2, 2019.89.1, Magyaregregy, Vágyomvölgy: PBO 2019.28.2.

Description. Length of stem/pedicel up to $0.6 \mathrm{~cm}$, flowers $0.6-1.3 \mathrm{~cm}$ long, $0.4-0.9 \mathrm{~cm}$ wide, detached tripartite or four calyces laterally compressed. Shape of sepals ovate, apex acute, base rounded.

Discussion. The specimens vary greatly in size. Similar fossils were reported from the late Eocene flora of Kučlin and were assigned by Ettingshausen (1868) to Diospyros subgen. Macreightia. In revising the flora, Kvaček and Teodoridis (2011) could not verify Ettingshausen's view, due to poor preservation of the fossil remains. In Kučlin it is a frequent fossil but in Magyaregregy a very rare element.

\section{Malvaceae}

\section{Sterculia sp.}

Pl. 23, figs 7-9

Material. Magyaregregy: PBO 2013.183.2, 2017.109.1.

Description. Original length of leaves up to $8 \mathrm{~cm}$, original width up to $6 \mathrm{~cm}$. Shape of lamina oval, base slightly cordate. Apex attenuate. Venation camptodromous, brochidodromous. Midvein strong, first pair of secondaries (basal veins) diverges from base. Distance between first and second pairs of secondaries larger than distance between higher secondaries. Margin entire except for one large side lobe/tooth on one side of leaf. First secondary vein ends in side lobe/tooth.

Discussion. Leaf morphology suggests that it may represent the genus Sterculia.

\section{Tilia sp.}

Pl. 23, fig. 6

Material. Magyaregregy: PBO 2007.111.1.

Description. Fragmentary bract with petiole. Petiole $1.6 \mathrm{~cm}$ long, bract fragment $4.6 \mathrm{~cm}$ long, original length $\sim 6 \mathrm{~cm}$. Width $1.8 \mathrm{~cm}$ measured close to base, apparently the widest part of the bract. Shape of bract elongate, tapering apically. Margin entire, slightly wavy. Midvein very strong in basal part, upwards damaged. Secondaries widely spaced, irregular, forming loops along margin.

Discussion. Tilia is frequently represented by leaves, infructescences, bracts and pollen in Tertiary floras of the Northern Hemisphere. In Europe it is a rare accessory element, mainly in Miocene floras. In the early Miocene flora of the Cypris Shale (western Bohemia) an elongate bract was also described (Bůžek et al., 1996) as Tilia sp. This type of bract as well as the one from Magyaregregy may belong to the B type according to the classification outlined by Manchester (1994).

From the European Oligocene of Manosque (France) and Bechlejovice (Bohemia), different broadly oval bracts were described as Tilia brassicoides (Kvaček and Walther, 2004). From Parsclug, T. longebracteata was described by Kovar-Eder et al. (2004). Leaves are much more frequent in the Tertiary floras of Europe but they always occur as a rare accessory element.

\section{Craigia bronnii}

(Unger) Kvaček, Bůžek et Manchester

$$
\text { Pl. 23, figs 5, } 10
$$

1837-38 Ulmus (?Europaea) Bronn; Bronn, p. 14, pl. 35, fig. 12, p. 864, (nom. inval.).

1845-47 Ulmus bronnii Unger; Unger, p. 100, pro parte, pl. 26, figs $2-4$.

1948 Pteleaecarpum bronnii (Unger) Weyland; Weyland, p. 130, pl. 21, fig. 5, text-figs 5-9.

1969 Pteleaecarpum europaeum (Unger) Bůžek et Erw. Knobloch; Knobloch, p. 123, pl. 23, figs $3,3 a$, pl. 44, fig. 5 .

1971 Pteleaecarpum europaeum (Bronn) Bůžek et Erw. Knobloch; Bůžek, p. 70, pl. 31, figs 1-21.

1991 Craigia bronnii (Unger) Kvaček, Bůžek et Manchester; Kvaček et al., p. 522.

2000 Craigia bronnii (Unger) Kvaček, Bůžek et Manchester; Sakala, p. 63, pl. 6, fig. 6 .

2002a Craigia bronnii (Unger) Kvaček, Bůžek et Manchester; Kvaček et al., p. 1, pl. 2, figs 1, 2, 4-10.

2004 Craigia bronnii (Unger) Kvaček, Bůžek et Manchester; Kvaček, p. 162, Fig. 3: 1-6. 
2004 Craigia bronnii (Unger) Kvaček, Bůžek et Manchester; Kvaček and Walther, p. 18, pl. 9, figs 5-7, text-fig. 13.10.

2004 Craigia bronnii (Unger) Kvaček, Bůžek et Manchester; Kovar-Eder et al., p. 66, pl. 6, figs 16, 17.

Material. Magyaregregy, Vágyom-völgy: PBO 2004.128.2, 2007.236.2.

Description. Isolated oval-obovate capsule valves, valves $1.5 \mathrm{~cm}$ long, $1-1.1 \mathrm{~cm}$ wide, with central locular area surrounded by winged board. Wing prominently reticulate-veined; main veins originate from distinct middle line, running radially, mostly straight, anastomosing with cross veinlets of higher order. Seed cavity two-loculed, oval to obovate in outline. Seeds not observed.

Discussion. Among the more than a thousand fossils, only two valves were found at the Magyaregregy, Vágyom-völgy site. The genus Craigia is represented by two living species growing in southern China and North Vietnam. These trees grow on calcareous basement in
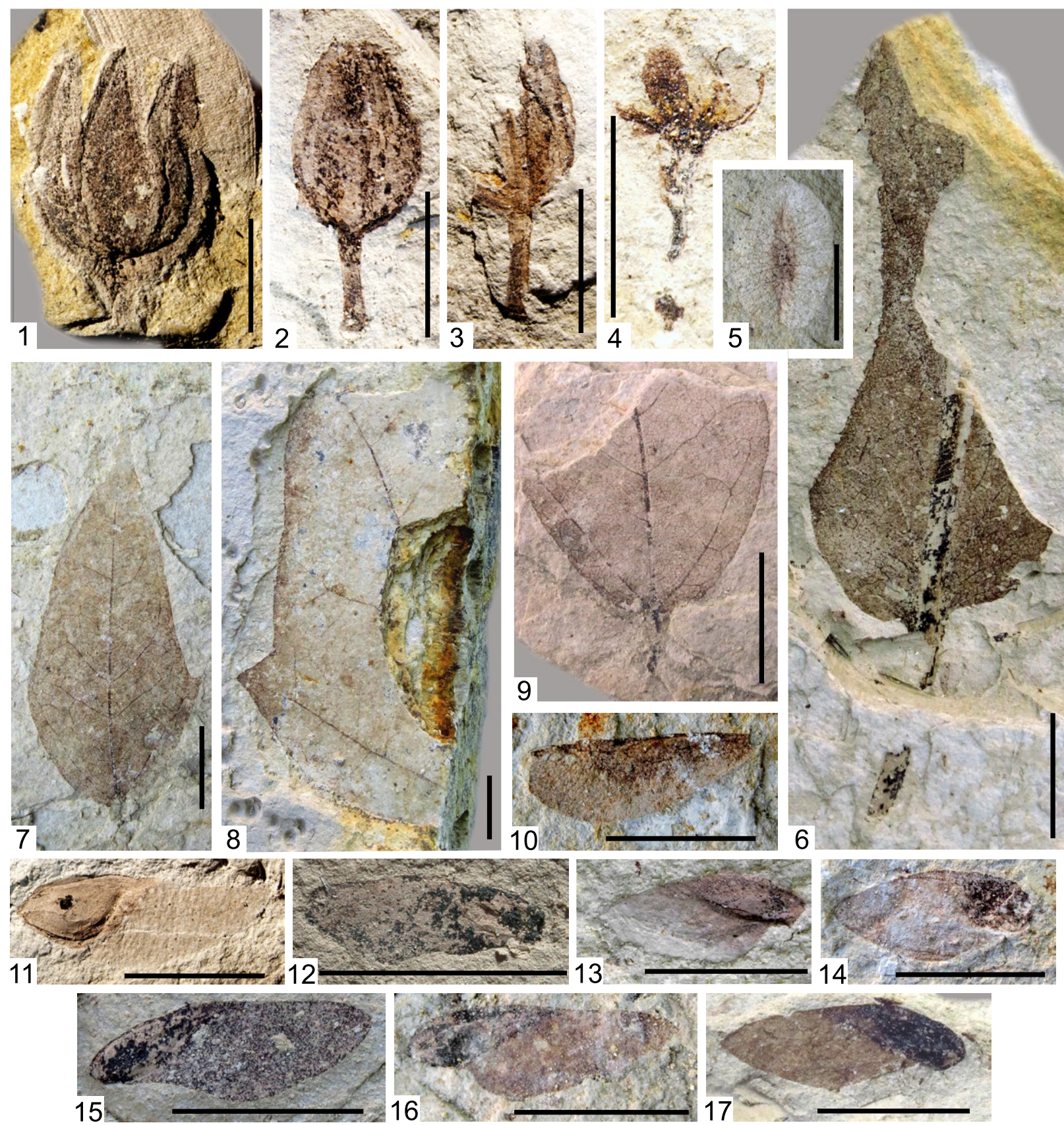

Plate 23. 1-4. Diospyros? microcalyx (Ettingshausen) Kvaček et Teodoridis, flower, 1. PBO 2019.27.1, 2. PBO 2019.28.2, 3. PBO 2019.28.2. counterpart, 4. PBO 2019.89.1; 5. Craigia bronnii (Unger) Kvaček, fruit, PBO 2004.128.2; 6. Tilia sp., bract, PBO 2007.111.1; 7-9. Sterculia sp., leaf, 7. PBO 2013.183.2, 8. PBO 2017.109.1, 9. PBO 2013.183.2, counterpart; 10. Craigia bronnii (Unger) Kvaček, fruit, PBO 2007.236.2; 11-17. Gordonia sp., winged seed, 11. PBO 2018.369.1, 12. PBO 2002.618.1, 13. PBO 2017.100.2, 14. PBO 2017.101.2, 15. PBO 2007.22.2, 16. PBO 2017.98.1, 17. PBO 97.142.1. Scale bar = $1 \mathrm{~cm}$ 
broad-leaved evergreen and deciduous mixed forest at 1400-1700 $\mathrm{m}$ a.s.l., mainly in humid climate (Sakala, 2000).

\section{Oleaceae}

\section{cf. Fraxinus sp. fruit}

Material. Magyaregregy: PBO 2002.619.2.

Description. Fruit with distal wing, elongate in shape, $1.7 \mathrm{~cm}$ long, $0.6 \mathrm{~cm}$ wide, apex and base missing. Venation fine, parallel, without distinct midvein. Fruit body dark, structureless, $0.6 \mathrm{~cm}$ long, $0.2 \mathrm{~cm}$ wide.

Dis c u s si on. Poor preservation prevents comparison with fossil and modern species. Among the numerous fossils only one specimen represents this genus. In the Miocene flora of the Mecsek Mts it probably was rare. Leaf remains do not occur in the area. Fraxinus fruits have been mentioned from Central Europe from the Pětipsy Area, North Bohemian Basin (Bůžek, 1971), from the Cypris Shale (western Bohemia) (Bůžek et al., 1996), from baked rocks of North Bohemia (Kvaček and Hurnik, 2000) as Fraxinus macroptera, from Parschlug (KovarEder et al., 2004) as Fraxinus primigenia, and from several other localities. It was generally a rare accessory element, but occasionally a dominant element as at Reith bei Unterstorcha, Austria (Kovar-Eder and Krainer, 1991).

\section{Apocynaceae}

\section{Nerium sp.}

Pl. 24, figs 2-4

Material. Abaliget, Kiskó-hegy: PBO 2017.33.1, Magyaregregy: PBO 2002.600.3, 2016.132.1-2016.140.1, 2016.147.1, 2016.284.22016.289.1, 2016.314.2, 2017.59.2, 2017.110.1, 2017.137.1, 2018.251.2, 2018.252.2, cf. 2019.68.2, 2019.72.4.

Des cription. Simple coriaceous leaves, width up to $1.6 \mathrm{~cm}$, length $11.2 \mathrm{~cm}$. Lamina shape narrow oblong to lorate, apex acute to obtuse, base cuneate to decurrent, margin entire. Petiole strong, straight. Midvein strong, straight, secondaries densely spaced, very thin, of almost the same thickness, originating at wide angles, running parallel and forming loops near margin.

Discussion. Similar leaves were described from Parschlug (Kovar-Eder et al., 2004) as
Nerium sp. In the European Tertiary, especially in the Miocene, it was recorded at some localities from Germany, Bulgaria and Romania (Kovar-Eder et al., 2004). Nerium was an evergreen, drought-tolerant, accessory element in the flora of the Mecsek Mts.

\section{Nyssaceae}

\section{Nyssa gyoergyi Hably sp. nov.}

Pl. 25, figs 1,2

Holotype. PBO 2017.155.2.

Paratype. PBO 2017.95.2.

Derivatio nominis. In honour of Dr György Szakmány, geologist, a collector at Magyaregregy through many years.

Locus typicus and stratum typicum. Vágyom-valley near Magyaregregy village, Baranya County, Mecsek Mts, Hungary; fishscale-bearing clay marl belonging to the Feked Formation, Komló Claymarl Member, dated as Karpatian (late Burdigalian).

Diagnosis. Simple, relatively large leaves, shape elliptic, base asymmetric cuneate. Margin densely and regularly serrate, teeth small and simple. Venation semicraspedodromous, secondaries bifurcating, forming Y shape, joining in loops. Intersecondaries depart between secondaries.

Description. Simple leaves, lamina shape elliptic, length of lamina up to $9.7 \mathrm{~cm}$, width up to $5.0 \mathrm{~cm}$. Base asymmetric, cuneate, apex not preserved. Venation semicraspedodromous, midvein strong, especially thick at basal part of lamina, secondaries regular, bifurcating, forming $\mathrm{Y}$ shape 1-1.8 $\mathrm{cm}$ from margin and ending in tooth apices. Secondaries often forming several loops. Between secondaries, intersecondaries depart from midvein. Margin densely and \pm regularly serrate. Teeth small, both apical and basal sides of teeth concave, tooth apex acute, sinuses angular.

D i s c u s si on. In the fossil record, Nyssa haidingeri (Ettingshausen) Kvaček et Bůžek is the most frequent fossil species of Nyssa. Leaves of this species are entire-margined, unlike the leaves from Magyaregregy, which are toothed. On the other hand, the venation is very similar in the two species (see also Kvaček and Bůžek, 1972: pl. 2, fig. 2). Nyssa cf. haidingeri 

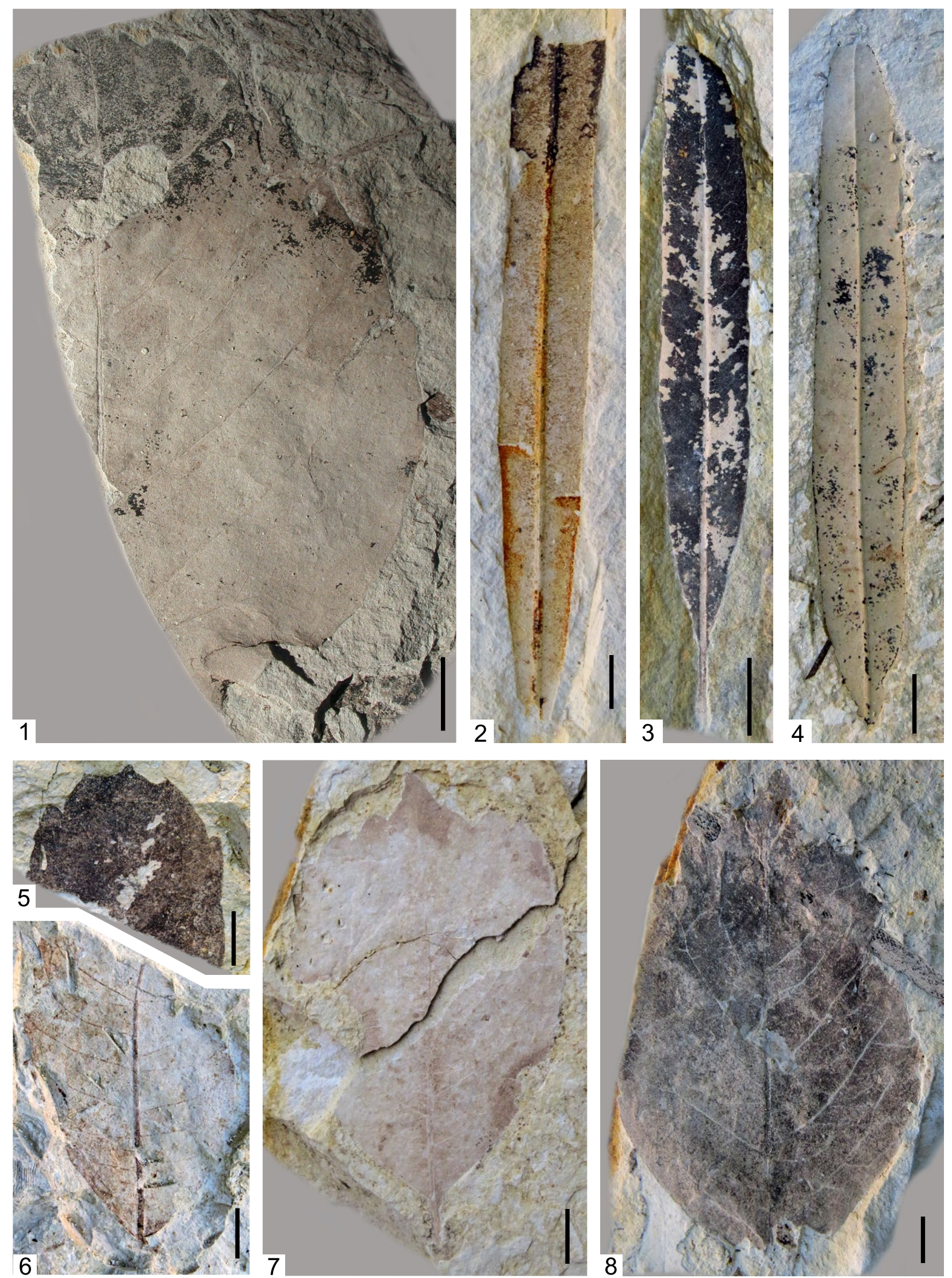

Plate 24. 1. Nyssa gergoei Hably sp. nov., leaf, paratype, PBO 2002.638.1, 2-4. Nerium sp., leaf, 2. PBO 2017.59.2, 3. PBO 2016.133.1, 4. PBO 2016.286.2; 5-8. Nyssa gergoei Hably sp. nov., leaf, 5. paratype, PBO, 2017.55.2, 6. paratype, PBO, 2013.190.1, 7. holotype, PBO 2013.184.1, 8. paratype, PBO 2016.308.2. Scale bar $=1 \mathrm{~cm}$ 
was described from the North Bohemian Basin (Kvaček and Bůžek, 1972) and later mentioned from several localities including Wackersdorf, Germany (Knobloch and Kvaček, 1976), and North Bohemia (Kvaček and Hurnik, 2000). Leaves of some extant Nyssa species have a serrate leaf margin (e.g. Nyssa sinensis) or the leaves are variable, both entire-margined and serrated. In the Mecsek flora, several fruits and leaves represent the genus Nyssa, but this species occurs only in the Magyaregregy, Vágyom-völgy locality.

\section{Nyssa gergoei Hably sp. nov.}

Pl. 24, figs 1, 5-8

Holotype. PBO 2013.184.1, Pl. 24, fig. 7.

Paratype. PBO 2002.638.1, 2013.190.1, 2016.308.2, 2017.55.2, Pl. 24, figs 1, 5, 6, 8.

Derivatio nominis. In honour of $\mathrm{Dr}$ Gergó Szakmány, a collector at Magyaregregy through many years.

Locus typicus and stratum typicum. Outcrop near Magyaregregy village, Baranya County, Mecsek Mts, Hungary; fish-scale-bearing clay marl belonging to the Feked Formation, Komló Claymarl Member, dated as Karpatian (late Burdigalian).

Di a g n o s i s. Large leaves, shape ovate to obovate, base cuneate, apex acute. Margin entire at least in basal third of lamina, teeth very large at apical part of lamina. Apex of teeth obtuse. Midvein strong, secondaries bifurcate near margin, joining each other, forming loops and ending in tooth apices.

Description. Simple leaves up to $10.5 \mathrm{~cm}$ long and $9 \mathrm{~cm}$ wide, rarely with short $(0.8 \mathrm{~cm})$ petiole. Lamina shape generally ovate, rarely obovate, base cuneate or not preserved, apex acute or often damaged. Midvein strong, secondaries thin, bifurcating near margin, joining each other, forming loops and ending in tooth apices. Margin entire at basal third of lamina, in some cases entire up to apical third of lamina. Teeth small and irregular at middle part of lamina, teeth very large at apical part of lamina. Apex of large teeth obtuse.

Discussion. These leaves differ in many aspects from the two above-mentioned Nyssa species as well as from the frequently described fossil species Nyssa haidingeri; especially the teeth are very characteristic for this species. The genus is a characteristic member of wetland forests. In the Mecsek Mts it probably occurred together with other swamp elements such as Glyptostrobus europaeus and Myrica lignitum.

\section{Nyssa sp. 1 leaf}

Pl. 25, fig. 3

Material. Magyaregregy: PBO 97.71.2.

Description. Simple leaf, lamina $9.9 \mathrm{~cm}$ long, $6.5 \mathrm{~cm}$ wide, lamina shape ovate, base asymmetric, cuneate, apex not preserved. Midvein strong, especially thick at basal part. Secondaries bifurcate near margin, forming a Y shape and ending in tooth apices. Margin irregularly toothed, teeth large, apical and basal sides of teeth concave or straight.

Dis cus sion. This leaf differs from Nyssa gergoei Hably first of all in the leaf margin pattern, but also in shape and venation. Intersecondaries are not observable in this single specimen.

\section{cf. Nyssa div. sp.}

M a te r i a l. Magyaregregy: PBO cf. 2002.637.1, 2017.54.2, 2019.20.1, Magyaregregy, Farkasordító-árok: PBO 2006.478.1, cf. 2006.508.1.

Description. Small leaf fragments showing characters of Nyssa.

Discussion. These leaves could belong to one of the above-mentioned species, but poor preservation prevents more precise determination of their systematics.

\section{Nyssa sp. endocarp}

Pl. 25, figs 4-10

Material. Magyaregregy: PBO 2002.639.4, 2002.640.2-2002.645.2, cf. 2017.56.1, cf. 2017.57.1, cf. 2017.136.1, 2019.4.1, Magyaregregy, Farkasordító-árok: PBO 2006.507.1, Magyaregregy, Vágyom-völgy: 2004.137.1, 2007.234.2.

Description. Secondarily compressed endocarps, almost oval in outline, up to $1.7 \mathrm{~cm}$ long and $1.2 \mathrm{~cm}$ wide. Rounded at one end, narrowed to a point at the other. Longitudinal ribs on surface visible in some but not all specimens.

Discussion. Flattened Nyssa endocarps were mentioned from Bohemia (Bůžek, 1971; 

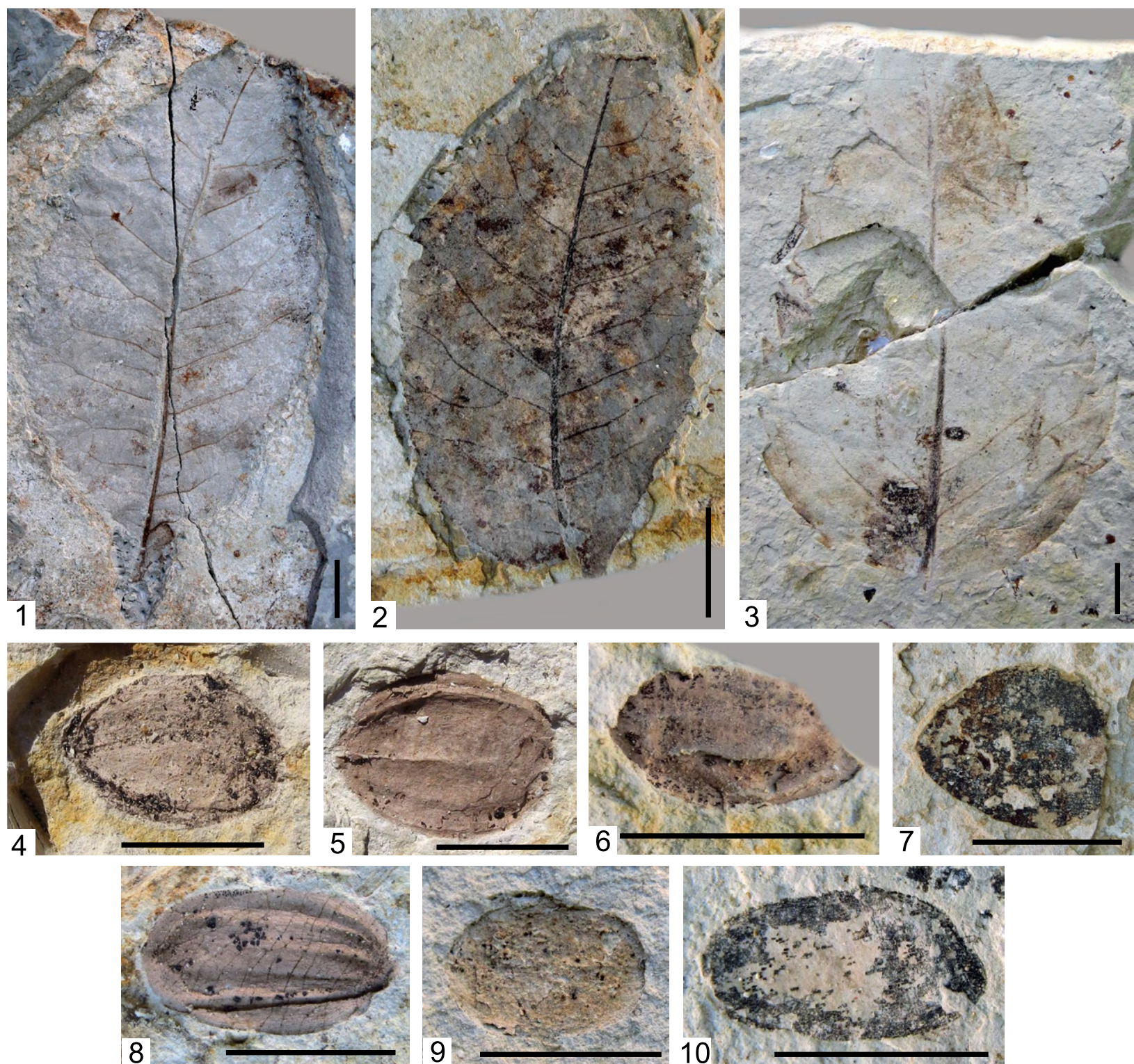

Plate 25. 1, 2. Nyssa gyoergyi Hably sp. nov., leaf, 1. holotype, PBO 2017.155.2, 2. paratype, PBO 2017.95.2; 3. Nyssa sp. 1, leaf, PBO, 97.71.2; 4-10. Nyssa sp., endocarp, 4. PBO 2002.642.1, 5. PBO 2002.643.1, 6. PBO 2002.645.2, 7. PBO 2002.644.2, 8. $\mathrm{PBO} 2002.640 .2$, 9. PBO 2017.56.1, 10. PBO 2017.57.1. Scale bar $=1 \mathrm{~cm}$

Kvaček and Hurnik, 2000) as Nyssa sp. Also described from Bohemia, on the basis of a complete endocarp, was Nyssa ornithobroma Unger (Bůžek et al., 1996). Generally, complete endocarps are required for determination of Nyssa endocarps to species level. Unfortunately, at Magyaregregy only compressed specimens are available.

\section{Ranunculaceae}

\section{Clematis csabae Hably sp. nov.}

Pl. 26, figs 1,2

Holotype. Magyaregregy: PBO 2017.106.2.

Derivatio nominis. In honour of $\mathrm{Dr}$
Csaba Szakmány, a collector at Magyaregregy through many years.

Locus typicus and stratum typicum. Outcrop near Magyaregregy village, Baranya County, Mecsek Mts, Hungary; fish-scale-bearing clay marl belonging to the Feked Formation, Komló Claymarl Member, dated as Karpatian (late Burdigalian).

Di a g n o s is. Lamina asymmetric, base acuminate, apex acute, margin irregularly serrate. Teeth simple, large. Midvein strong, two basal veins depart from base, joining secondaries in upper third of lamina and forming loops.

Description. Lamina asymmetric, ovate, $1.6 \mathrm{~cm}$ long, $1.0 \mathrm{~cm}$ wide. Base acuminate, 

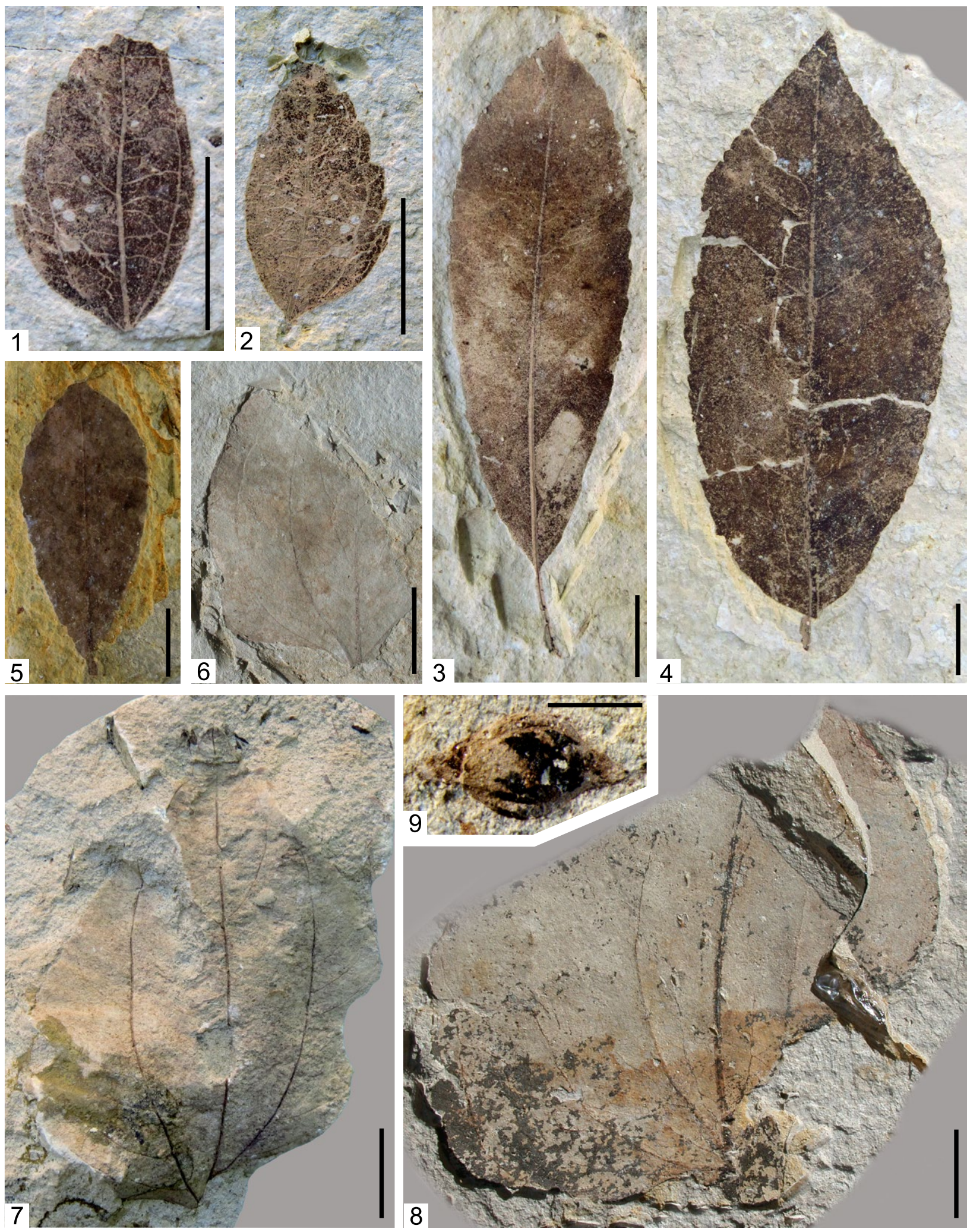

Plate 26. 1, 2. Clematis csabae Hably sp. nov., leaf, holotype, 1. PBO 2017.106.2, 2. PBO 2017.106.2. counterpart; 3-5. Arbutus sp., leaf, 3. PBO 97.94.2, 4. PBO 2013.193.2, 5. PBO 2002.611.2; 6-8. Smilax weberi P. Wessel, leaf, PBO 2002.616.1, 7. PBO 2006.529.1, 8. PBO 2002.615.1; 9. Cladiocarya sp., fruit, PBO 2017.17.1. Scale bar $=1 \mathrm{~cm}$

apex acute, margin asymmetric serrate. Teeth asymmetrically arranged: on one side of lamina, occurring only on apical part; on the other side, teeth located along whole length of lamina. Teeth simple, large, apical side of teeth shorter than basal side. Sinuses angular, tooth apex acute. Midvein strong. Two basal veins depart from base, joining secondaries and forming loops in upper third of lamina; in lower two-thirds, no secondaries branching 
from midvein. Tertiary venation observable between basal veins and midvein. Epimedial tertiaries alternate percurrent. From basal veins, thinner veins branch, ending in tooth apices.

Discussion. The gross morphology of the leaf recalls that of Celtis leaves but many traits distinguish them. The shape of Celtis leaves is slightly asymmetric: secondary veins depart from the midvein at acute (low) angles and are curved as running towards the margin. Tertiary veins are epimedial, opposite percurrent. The margin is regularly toothed on both sides of the leaf.

Most of the modern Clematis species are lianas, occurring in the Northern Hemisphere. Several species are deciduous, but evergreen species are also known. Fossil Clematis is rare in Tertiary floras. Fossil leaves of this genus have not been described in the palaeobotanical literature. Seeds of $C$. flammula fossils were mentioned by Szafer (1961) from the Miocene Flora of Stare Gliwice in Upper Silesia. The earliest reliable fossilized fruits of Clematis in the Oligocene of Western Europe were published by Reid and Chandler (1926) from the Bembridge flora and by Weyland (1938) from Germany. Clematis is a very rare element in the Miocene flora of the Mecsek Mts. Among the 10000 specimens only one occurred; it was found in the largest locality.

\section{Ericaceae}

\section{Arbutus sp.}

Pl. 26, figs $3-5$

Material. Magyaregregy: PBO 97.94.2, 2002.611.2, 2013.193.2, 2013.195.2.

Des cription. Simple petiolate leaves. Length of petiole up to $1.9 \mathrm{~cm}$. Lamina obovate, up to $8.5 \mathrm{~cm}$ long, $3.2 \mathrm{~cm}$ wide. Base cuneate to rounded, apex acute, margin densely and regularly serrate except at basal part. Teeth among each other a bit irregular, small, simple, tooth apices acute to rounded. Apical side of teeth shorter than basal side, convex to straight, basal side convex. Venation semicraspedodromous. Midvein strong. Secondaries much thinner than midvein, forming loops near margin, where veins arise from secondaries and terminate in teeth. Thin intersecondaries between secondaries.
Discussion. A fossil leaf was documented by Andreánszky (1962) as Arbutus praeunedo from the late Oligocene (Egerian) flora of Eger, Wind brickyard. From the late Miocene/Pliocene flora of Kodor, Kolakovski (1964) described leaves as Arbutus elegans; these show similarities to our specimens. Most modern members of Arbutus are native to warm-temperate Mediterranean regions (e.g. Canary Islands).

\section{Smilacaceae}

\section{Smilax cf. weberi}

P. Wessel in P. Wessel et C.O. Weber

Pl. 26, figs 6-8

1847 Smilacites grandifolius Unger; Unger, p. 129, pl. 40 , fig. 3 .

1855 Smilax grandifolia (Unger) Heer; Heer, p. 82, pl. 30 , fig. 8.

1855 Smilax weberi P. Wessel; Wessel and Weber, p. 127 , pl. 21, fig. 1 .

1971 Smilax weberi P. Wessel; Bůžek, p. 89, pl. 44, figs $1-5$, pl. 45, figs 1-4, text-fig. 14 .

1975 Smilax weberi P. Wessel; Christensen, p. 21, pl. 5, figs $1-8$, pl. 6 , figs $2,4-6$, text-figs $6 \mathrm{~A}-\mathrm{F}$, $7,8$.

1976 Smilax weberi P. Wessel; Knobloch and Kvaček, p. 85, pl. 39, figs $1,3,6,7$, pl. 40, figs 1-3.

1992a Smilax weberi P. Wessel; Hably, p. 204, pl. 2, figs 5, 6 .

2013 Smilax weberi P. Wessel; Hably, p. 71, pl. 32, figs 3,4 .

Material. Magyaregregy: PBO 2002.615.1, 2002.616.1, Magyaregregy, Almás-patak: PBO 2006.529.1.

Description. Simple leaves, original length of leaves up to $8 \mathrm{~cm}$, fragments up to $6 \mathrm{~cm}$, width $7.4 \mathrm{~cm}$. Lamina broadly ovate to ovate, apex acute, base missing, margin entire.Venation campylodromous. In broadly ovate leaf 5 , in ovate leaf 3 primary veins, lateral primary veins slender, curving upwards, bending towards apex of lamina. Between lateral (marginal) primary vein and margin, marginal tertiary veins running toward margin, forming marginal loops.

Discussion. In the Miocene flora of the Mecsek Mts, Smilax leaves appear in both fish-scale marl and volcanic (rhiolitic tuff) sediments. Smilax weberi is known from the Egerian of Hungary (Hably, 1990) up to the Pannonian (Hably, 1992a, 2013) as a relict species. Later in the early Miocene it occurs in Ipolytarnóc (Hably, 1985a). From the Sarmatian, several 
species of Smilax were described by Andreánszky (1959); some of them (e.g. S. borsodensis Andreánszky) seem to be identical to $S$. weberi. Smilax is a warm-temperate, thermophilous liana.

\section{Cyperaceae}

\section{Cladiocarya sp.}

Pl. 26, fig. 9

1996 Cladiocarya sp.; Bůžek et al., p. 45, pl. 30, figs $1-4,7-11$.

Material. Magyaregregy: PBO 2017.17.1.

Description. Fruit, shape of fruit rounded, slightly oval with elongate apex; $0.25 \mathrm{~cm}$ long including elongate apex, $0.11 \mathrm{~cm}$ wide.

Discussion. From the Miocene flora of the Cypris shale (western Bohemia), Bůžek et al. (1996) described several species of the genus and many specimens as Cladiocarya sp. The fruit without a petiole and with an elongate apex is similar to specimens illustrated and described as Cladiocarya sp. The occurrence of Cladiocarya confirms the presence of aquatic plants in the Miocene flora of the Mecsek Mts.

Arecaceae

\section{Palmacites sp.}

Pl. 27, fig. 1

Material. Magyaregregy: PBO 2000.490.2.

Description. Leaf palmate, lacking costa or extension of petiole into blade. Petiole $6.9 \mathrm{~cm}$ long, $0.6 \mathrm{~cm}$ wide. Lamina very fragmentary: only base, attachment of petiole and basal part of segments preserved. Original length of lamina $\sim 10 \mathrm{~cm}$.

Dis cus sion. According to Read and Hickey's fossil palm leaf classification (Read and Hickey, 1972), this palm leaf fragment is assigned to Palmacites. A similar palm leaf was reported from Hungary, from the Sarmatian flora of Erdóbénye, mentioned as Sabalites (Erdei and Hír, 2002), which is in fact also pure palmate, not costapalmate. From the early Miocene flora of Ipolytarnóc, Hably (1985a) described palmate leaves as Sabal major, but the attachment of the lamina and the petiole is not well preserved or is lacking in the specimens. Palms generally indicate warm subtropical climate.

\section{Monocotyledonae gen. et sp.}

Pl. 27, figs 2-4

Material. Kisbattyán: PBO 2012.160.2, 2012.161.1, Magyaregregy: PBO 2016.295.2, 2017.8.2-2017.12.1, 2017.66.1, 2017.76.1, 2017.77.1, 2017.127.2, 2017.137.1, 2017.138.1, 2018.240.2, 2018.245.1, 2018.252.2, 2018.254.1, 2018.255.1,2018.258.1,2018.266.2,2018.2727.2, 2018.284.2, 2018.285.2, 2018.302.2-2018.303.2, 2018.321.1, 2019.16.1, 2019.20.1, 2019.22.3, $2019.23 .2, \quad 2019.51 .2, \quad 2019.54 .1, \quad 2019.66 .1$, 2019.71.1, 2019.74.2, 2019.78.1, 2019.85.2, 2019.87.1, Magyaregregy, Farkasordító-árok: PBO 2006.473.1, 2006.490.1-2006.493.1, 2016.146.2, Magyaregregy, Leánykói-árok: PBO2016.100.1-2016.102.1, Magyaregregy, Vágyom-völgy: 2002.335.2, 2002.349.2, 2002.350.1, 2002.363.2, 2002.364.2, 2004.108.2, 2004.139.1-2004.142.2.

Des cription. Linear leaf fragments of varying length and width. Margin entire, venation parallel.

Dis c u s si on. Fragments, presumably belonging to various species and genera. The shape of the leaves as well as their parallel venation indicate that they belong to monocotyledonous plants. In the fossil material, monocots mainly represent the autochthonous part of the fossil assemblage, since their transport is limited to short distances.

Angiosperms incertae sedis

\section{Antholites stiriacus \\ Kovar-Eder et Kvaček \\ Pl. 27, figs 5-11}

1850a Celastrus elaenus Unger; Unger, 459, pro parte. 1864 Prinos hyperboreus Unger; Unger, p. 14, pro parte, pl. 3, figs $34 \mathrm{a}$, b.

1889 Hieracites stellatus Saporta; Saporta, p. 56, pl. 17, figs 12-14.

2004 Antholites stiriacus Kovar-Eder et Kvaček; Kovar-Eder et al., p. 86, pl. 15, figs 13-15.

Material. Magyaregregy: PBO 2000.248.2, 2003.501.2-2003.539.1, 2006.562.1-2006.563.2, 2006.751.2-2006.753.1, 2006.761.1, 2007.30.1, 2007.36.2-2007.39.1, 2013.161.1, 2016.297.2, 2016.308.2, 2017.79.1, 2017.130.2, 2017.131.1, 2018.240.2-2018.247.2, 2018.252.2, 2018.284.2, 2018.291.1, 2019.12.1, 2019.70.2, 2019.73.3, Magyaregregy, Kisréti-árok: PBO 2006.514.1, 2006.515.1, Magyaregregy, Leánykóí-árok: PBO 

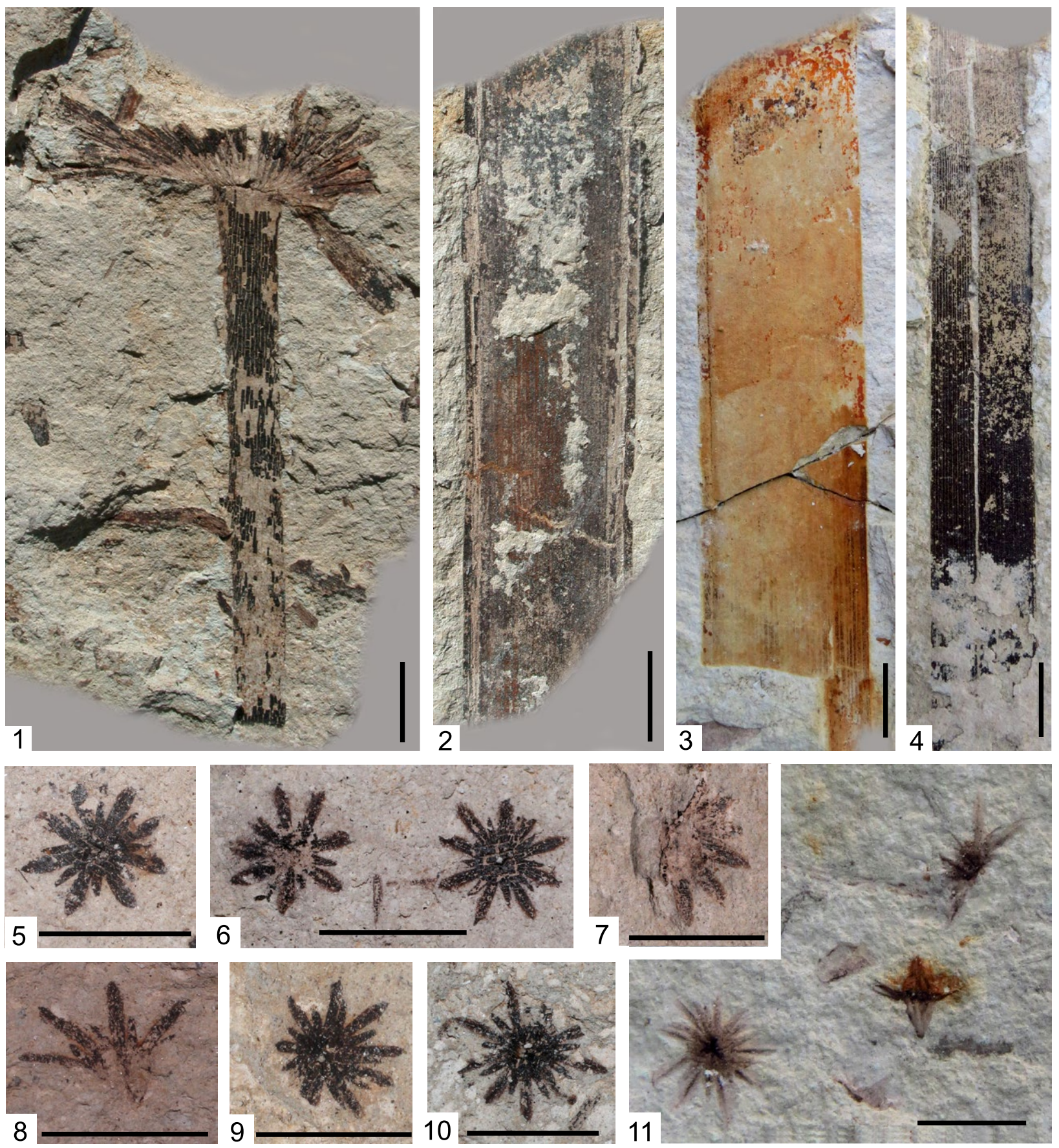

Plate 27. 1. Palmacites sp., leaf, PBO 2000.490.2; 2-4. Monocotyledonae gen. et sp., leaf, 2. PBO 2000.366.2, 3. PBO 2000.361.1, 4. PBO 2000.359.2; 5-11. Antholites stiriacus Kovar-Eder et Kvaček, flower, 5. PBO 2007.30.1, 6. PBO 2003.527.3, 7. PBO PBO 2003.518.1, 8. PBO 2003.527.3, 9. PBO 2003.524.1, 10. PBO 2003.516.1, 11. PBO 2003.531.2. Scale bar = 1 cm (1-4); scale bar $=5 \mathrm{~mm}(5-11)$

2006.455.1, 2006.460.1, 2016.72.1-2016.75.1, Magyaregregy, Vágyom-völgy: PBO 2004.108.22004.117.1.

Description. Flower short-stalked, actinomorphic, octomeric, half-epigynous, $5-6 \mathrm{~mm}$ in diameter, calyx shortly synsepalous, $2.5 \mathrm{~mm}$ long, $0.5 \mathrm{~mm}$ wide, free. Sepals free, very narrow elliptic, $1-2 \mathrm{~mm}$ long, $0.3 \mathrm{~mm}$ wide.

Discussion. Similar flowers were found in the Miocene flora of Parschlug, and revised and discussed by Kovar-Eder et al. (2004). The same species was described in the Miocene flora of Schönegg (Ettingshausen, 1890). In Magyaregregy this species is quite abundant.

\section{Dicotylophyllum sp. 1}

Pl. 28, figs $3-5,9$

Material. Magyaregregy: PBO 2017.84.22017. 88.2, Magyaregregy, Vágyom-völgy: PBO 2017.89.2. 
D e s c r i p ti o n. Length of lamina up to $14.2 \mathrm{~cm}$, width $4.6 \mathrm{~cm}$. Shape of lamina ovate, apex attenuate, base cuneate to rounded, margin entire. Venation brochidodromous, midvein strong, straight, secondaries join in loops with plural loop system near margin. Strong basal pair of secondaries departs from midvein. Distance between basal pair of secondaries and next pair of secondaries larger than distance between other secondary vein pairs on lamina. Major secondaries festooned brochidodromous. Intersecondaries parallel to major secondaries, tertiary venation irregular reticulate.

Discussion. A similar leaf was described by Bůžek et al. (1976) from the Oligocene volcanic flora of Markvartice as Dicotylophyllum maii. This species was described based on its cuticle; therefore this name cannot be used for the leaf. The strong basal pair of secondaries characteristic of many malvalean leaves is clearly observable in the leaves from Magyaregregy, which perhaps also belong to this group. The large, entire-margined leaves with an attenuate base suggest tropical-subtropical climate conditions.

\section{Dicotylophyllum sp. 2}

Pl. 28, fig. 8

Material. Magyaregregy: PBO 2019.21.2.

De s c ripti o n. Lamina lanceolate, $14 \mathrm{~cm}$ long, $2.4 \mathrm{~cm}$ wide. Base not preserved, apex acute, margin entire. Venation camptodromous, brochidodromous. Secondary veins depart steeply from midvein, running upwards and joining each other. Distance between secondaries up to $1.7 \mathrm{~cm}$. Lamina surface dotted, presumably formed by hair bases or glands.

D i s c u s s i o n. There are hair bases on the whole lamina surface, which indicate a hairy leaf. The systematic affinity of the leaf is unknown.

\section{Dicotylophyllum sp. 3}

Pl. 28, fig. 6

Material. Magyaregregy-Vágyomvölgy: PBO 2019.35.1.

Description. Basal part of leaf with $2.6 \mathrm{~cm}$ long petiole. Base auriculate/sagittate. Petiole and midvein strong, venation palmate, basal actinodromous. Minor secondaries running from secondary veins toward margin. Margin damaged.
Discussion. In gross morphology, the type of leaf venation suggests that it may belong to Malvaceae or Araceae.

\section{Dicotylophyllum sp. 4}

Pl. 28 , fig. 7

Material. Magyaregregy: PBO 2019.36.2.

Description. Simple, petiolate leaf, $2.4 \mathrm{~cm}$ long, $1.5 \mathrm{~cm}$ wide, petiole $0.4 \mathrm{~cm}$ long. Lamina shape ovate, base decurrent, apex obtuse. Margin entire, venation camptodromous, brochidodromous. Secondaries very thin, dense reticulate tertiary venation visible between secondaries.

Discussion. Although small leaves recalling leaflets of Leguminosae are frequent in the Mecsek flora, the gross morphology of the leaf, the entire margin, venation and its state of preservation suggest a laurel leaf. It differs from leaflets of Leguminosae, with symmetrical laminae, and the leaf base is also not typical of legumes.

\section{Dicotylophyllum sp. 5}

Pl. 28, fig. 11

Material. Magyaregregy, Vágyom-völgy: PBO 2019.62.1.

Description. Simple petiolate leaf, petiole strong, $1.2 \mathrm{~cm}$ long. Lamina lanceolate, $6.5 \mathrm{~cm}$ long, $2.0 \mathrm{~cm}$ wide. Base slightly asymmetrical, acute, apex missing. Midvein strong, secondaries barely visible because the material is carbonized. Venation probably semicraspedodromous. Margin toothed. Teeth small, regular, apical side of teeth much shorter than basal side, tooth apex obtuse.

\section{Dicotylophyllum sp. 6}

Pl. 28, fig. 10

Material. Magyaregregy, Vágyom-völgy: PBO 2019.63.1.

Description. Simple leaf. Lamina obovate, asymmetric, especially at basal part of lamina. Lamina length $10 \mathrm{~cm}$, width $6.2 \mathrm{~cm}$. Base decurrent, apex acute. Margin entire. Midvein strong. Secondaries run steeply upwards, termination of veins not visible due to poor preservation. 

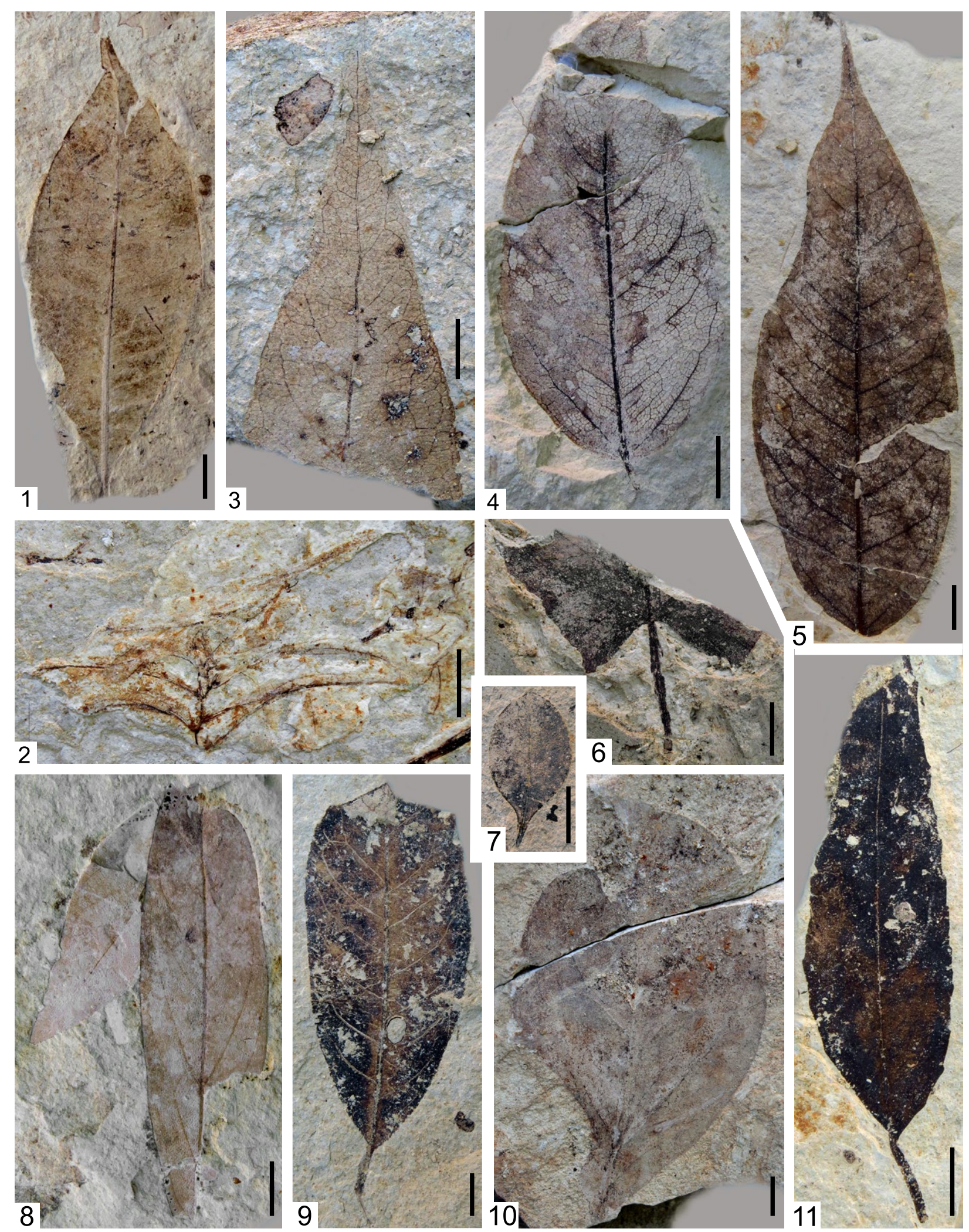

Plate 28. 1. "Ilex" falsani Saporta et Marion, leaf, PBO 2013.189.2; 2. Ceratophyllaceae?, leaf, PBO 2019.40.3; 3-5, 9. Dicotylophyllum sp. 1, 3. leaf apex, PBO 2017.84.2, 4. leaf, PBO 2017.88.2, 5. leaf, PBO 2017.89.2, 9. leaf, PBO 2017.86.2; 6. Dicotylophyllum sp. 3, leaf, PBO 2019.35.1; 7. Dicotylophyllum sp. 4, leaf, PBO 2019.36.2; 8. Dicotylophyllum sp. 2, leaf, PBO 2019.21.2; 10. Dicotylophyllum sp. 6, leaf, PBO 2019.63.1; 11. Dicotylophyllum sp. 5, leaf, PBO 2019.62.1. Scale bar $=1 \mathrm{~cm}$ 


\section{Dicotylophyllum sp. 7}

Pl. 29, fig. 11

Material. Magyaregregy: PBO 2019.102.2.

Description. Simple leaf with $1.2 \mathrm{~cm}$ long petiole. Base of petiole rounded, $0.3 \mathrm{~cm}$ wide. Lamina obovate, $7.5 \mathrm{~cm}$ long, $2.0 \mathrm{~cm}$ wide. Apex acute, base acuminate, margin entire. Venation brochidodromous. Midvein strong, straight; from the midvein several pair of secondaries running out.

\section{Dicotylophyllum sp. 8}

Pl. 29, fig. 12

Material. Magyaregregy: PBO 2019.103.1.

Description. Leaf fragment $6.3 \mathrm{~cm}$ long; original length of lamina $\sim 13 \mathrm{~cm}$. Width of lamina $3.2 \mathrm{~cm}$. Apex and base missing, margin entire, venation camptodromous, brochidodromous. Between secondaries, tertiary venation running perpendicular to secondaries.

\section{Dicotylophyllum sp. 9}

Pl. 29, fig. 13

Material. Magyaregregy: PBO 99.257.1.

Description. Simple leaf, lamina ovate, length of lamina $4.3 \mathrm{~cm}$, width $1.9 \mathrm{~cm}$. Apex acute, base slightly asymmetrical, incomplete. Margin toothed. Teeth small, sharp, regular, tooth apex acute. Apical side of tooth much shorter than basal side. Venation craspedodromous. Midvein strong, slightly curved at base. Secondaries running out from midvein regularly, ending in tooth apices. Tertiary venation barely visible.

\section{Dicotylophyllum sp. 10}

Pl. 29, fig. 14

Material. Magyaregregy: PBO 2013.197.2.

Description. Leaf fragment $3.3 \mathrm{~cm}$ long, $1.3 \mathrm{~cm}$ wide. Lamina ovate, apex and base missing. Margin toothed even at basal part. Teeth small, regular, sharp. Tooth apex acute, apical part of teeth slightly shorter than basal part. Both sides straight. Venation craspedodromous to semicraspedodromous. Midvein stong, secondaries much thinner, tertiary venation barely visible.

\section{Carpolithes gergoei}

Hably et Erdei sp. nov.

Pl. 29, figs 15-18

Holotype. PBO 2019.32.2.

Paratypes. PBO 2019.31.1-2019.34.2, 2019.50.2.

Derivatio nominis. In honour of Dr Gergó Szakmány, a collector at Magyaregregy through many years.

Locus typicus and stratum typicum. Outcrop near Magyaregregy village, and Magyaregregy, Vágyom-völgy: Baranya County, Mecsek Mts, Hungary; fish-scale-bearing clay marl belonging to the Feked Formation, Komló Claymarl Member, dated as Karpatian (late Burdigalian).

Diagnosis. Capsules ovoid to obovoid, symmetrical, rarely slightly asymmetrical, 1.2$1.9 \mathrm{~cm}$ long, $0.5-0.7 \mathrm{~cm}$ wide. Convex, thickened dorsal surface with longitudinal sutures at middle of valve, as well as 1-1 suture running parallel and close to margin.

Discussion. The fruit capsules resemble some malvalean fruits. Detached fruit valves of Reevesia hurnikii belonging to Malvaceae were first described by Kvaček (2006) from the early Miocene flora of Bílina, northern Bohemia (Czech Republic). From the late Miocene flora of Bełchatów a capsule of Reevesia hurnikii was also mentioned by Worobiec et al. (2012). The fruits from Magyaregregy are not comparable to those of Reevesia hurnikii, which are asymmetrical valves of semilunar shape reaching up to $2 \mathrm{~cm}$ in size. The fruits from the Mecsek flora are smaller and symmetrical, and no dehiscence is observable.

\section{Carpolithes sp. 1}

Pl. 29, fig. 1

Material. Magyaregregy: PBO 2019.11.1.

Description. Multiple branched infructescence with small fruits. From shoots, fruit stalks branching in threes, each ending in one fruit. Fruits obovate, $0.12 \mathrm{~cm}$ long, up to $0.12 \mathrm{~cm}$ wide.

Discussion. The detailed structure of the carbonized, flattened fruits is unclear, preventing closer identification. Similar branched 


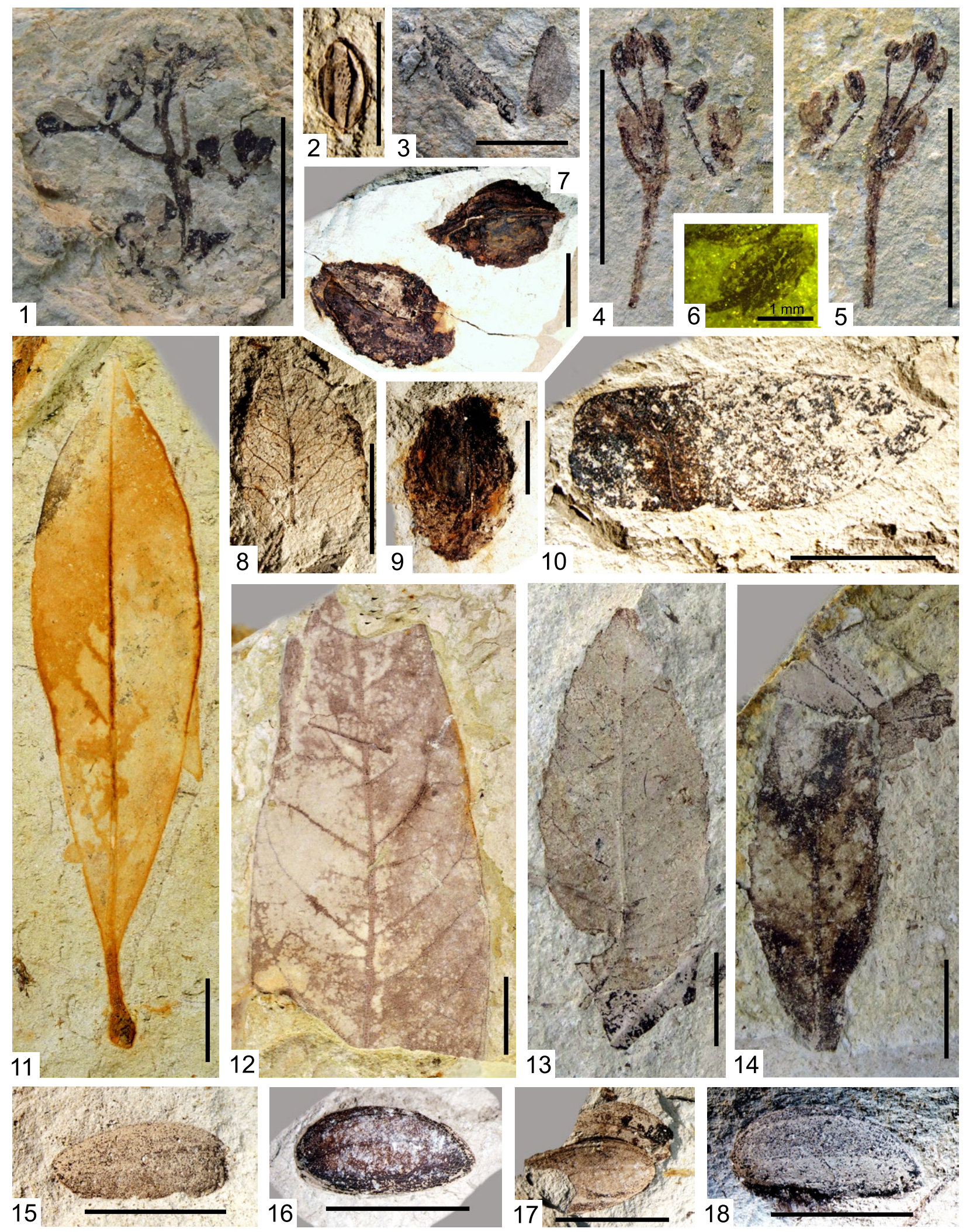

Plate 29. 1. Carpolithes sp. 1, fruit, PBO 2019.11.1; 2. Carpolithes sp. 2, fruit, PBO 2019.47.2, 3. Carpolithes sp. 3, fruit, PBO 2019.64.1; 4-6. Carpolithes sp. 4, 4. umbellate inflorescence, PBO 2019.10.2, 5. umbellate inflorescence, PBO 2019.10.2, counterpart, 6. anther, PBO 2019.10.2; 7. Carpolithes sp. 5, fruit and seed, PBO 2019.30.2; 8. cf. Hedera sp., leaf, PBO 2019.138.1, 9. Carpolithes sp. 5, fruit, PBO 2019.30.2; 10. Carpolithes sp. 6, winged fruit, PBO 2019.77.2; 11. Dicotylophyllum sp. 7, leaf, PBO 2019.102; 12. Dicotylophyllum sp. 8, leaf, PBO, 2019.103.1; 13. Dicotylophyllum sp. 9, leaf, PBO 99.257.1; 14. Dicotylophyllum sp. 10, leaf, PBO 2013.197.2; 15-18. Carpolithes gergoei Hably et Erdei sp. nov., fruit, 15. PBO 2019.31.1, 16. holotype, PBO 2019.32.2, 17. PBO 2019.34.2, 18. PBO 2019.50.1. Scale bar $=1 \mathrm{~cm}$ 
infructescences occur in the flora of Holý Kluk Hill near Proboštov (Czech Republic) (Radon et al., 2006). From Radoboj, Unger (1864) reported fruits with branching shoots and small capsules as Bursaria radobojana and "Povetta" borealis Unger (1866).

\section{Carpolithes sp. 2}

Pl. 29, fig. 2

Material. Magyaregregy: PBO 2019.47.2.

Description. Ovate fruit, $0.7 \mathrm{~cm}$ long, $0.4 \mathrm{~cm}$ wide, rounded at one end, other end shortly acute. Four strong ribs visible parallel to margin.

\section{Carpolithes sp. 3}

Pl. 29, fig. 3

Material. Magyaregregy, Vágyom-völgy: PBO 2019.64.1.

Description. Winged fruit, shape asymmetrical ovate. Length of fruit $1.0 \mathrm{~cm}$, width $0.45 \mathrm{~cm}$. Base rounded, apex acute, margin of wing entire. Seed $0.3 \mathrm{~cm}$ long, ovate.

\section{Carpolithes sp. 4}

Pl. 29, figs 4-6

Material. Magyaregregy: PBO 2019.10.2.

De s c ri i ti o n. Fragment of umbellate inflorescence with stem, sepal and three attached stamens, filament with anther. Further detached stamen located near flower. Stem $0.7 \mathrm{~cm}$ long, sepal $0.4 \mathrm{~cm}$ long. Stamens exserted up to $0.4 \mathrm{~cm}$ from sepal. Anther oval, $0.2 \mathrm{~cm}$ long, $0.1 \mathrm{~cm}$ wide. No pollen found around flower.

Discussion. Fossils of umbellate inflorescences are quite rare. Unger (1860: 24, pl. 9, figs 13,14$)$ described an umbellate inflorescence as Cissus oxycoccos fruit from Radoboj.

\section{Carpolithes sp. 5}

Pl. 29, figs 7, 9

Material. Magyaregregy, Vágyom-völgy: BP 2019.30.2.

Description. Fruit three-dimensionally preserved, length of fruit $2.3 \mathrm{~cm}$, width $1.6 \mathrm{~cm}$, shape slightly ovate. Specimen slightly compressed but original shape was spherical.
Endocarp? preserved inside fruit $2.2 \mathrm{~cm}$ long and $1.4 \mathrm{~cm}$ wide, its apex acute, base fragmented, acute. One strong ridge at midline of endocarp, thinner ridges towards margin.

Discussion. The structure of the fruit suggests a drupe.

\section{Carpolithes sp. 6}

Pl. 29, fig. 10

Material. Magyaregregy: BP 2019.77.2.

Description. Fruit samaroid, $2.5 \mathrm{~cm}$ long, $0.9 \mathrm{~cm}$ wide, shape elliptic, margin entire, apex of wing acute, base rounded. Seed located at base, $0.9 \mathrm{~cm}$ long, its axis \pm parallel to long axis of wing.

Discussion. The samara is different from Gordonia sp. in many aspects: shape of wing, shape of seed, position of seed versus wing, etc. It also differs from Saportaspermum in its larger dimensions and in the shape of the wing apex.

\section{cf. Hedera sp.}

Pl. 29. fig. 8

Material. Magyaregregy: BP 2019.138.1, 2019.139.2.

Description. Leaf fragment, $1.5 \mathrm{~cm}$ long, $1.1 \mathrm{~cm}$ wide, apex rounded, base not preserved, margin undulate. Major secondary venation festooned brochidrodromous.

Aquifoliaceae

“Ilex" falsani Saporta et Marion Pl. 28, fig. 1

1964 Ilex falsani Saporta et Marion; Kolakovski, p. 44, pl. 8, figs 3-9.

Material. Magyaregregy: PBO 2013.189.2.

Description. Length of leaf $11.2 \mathrm{~cm}$, width $3.8 \mathrm{~cm}$, shape of lamina elliptic, base cuneate, apex attenuate. Margin entire, thick. Midvein strong, secondaries fine and dense. Secondaries bifurcate near margin, forming a $\mathrm{Y}$ shape, and become very thin. Between secondaries, intersecondaries depart regularly from midvein.

Discussion. Similar leaves were mentioned by Kolakovski (1964) from the flora of Kodor. 


\section{Ceratophyllaceae?}

Pl. 28, fig. 2

Material. Magyaregregy, Vágyom-völgy: PBO 2019.40.3.

Description. Branching shoot with $0.8 \mathrm{~cm}$ long and $0.5 \mathrm{~mm}$ wide main axis. Branches alternately arranged. Uppermost branch of the four branches branching twice, last branches opposite. Length of branches up to $4 \mathrm{~cm}$, leaf blade unclear but suggested by thin venation fragments.

Discussion. Its preservation suggests an aquatic plant with a very thin leaf blade, presumably damaged during fossilization so that only the shoots were retained. The fossil shoot resembles an aquatic plant but it is not identical with Ceratophyllum schrotzburgense Hantke, which was a frequent aquatic plant of European Cenozoic floras (Kovar-Eder et al., 2002; Hably and Meller, 2017).

\section{THE KARPATIAN \\ (LATE EARLY MIOCENE) FLORA OF THE MECSEK MTS}

The Miocene flora of the Mecsek is dominated by angiosperms and gymnosperms, whereas pteridophytes are subordinate elements. Among the gymnosperms, Glyptostrobus europaeus (Brongniart) Unger of the family Cupressaceae s.l. played the most significant role, occupying swamp habitats as a typical element, though not dominant when considering the entire flora. Other representatives of the family Cupressaceae s.l., Cupressaceae gen. et sp. and Tetraclinis salicornioides (Unger) Kvaček were also recorded as rare accessory elements. Among Pinaceae, needles (two and three per fascicle) and seeds of Pinus and Abies were also described. Angiosperms predominate in the flora. Among Lauraceae, the most important taxon is Daphnogene but other taxa described as Laurophyllum are also present. One species of this genus, Laurophyllum markvarticense Kvaček, was identified based on cuticular analysis. Besides leaf remains, a lauraceous fruit, Laurocarpum sp., was also recorded. The family Berberidaceae is also present as an accessory element: Berberis andreanszkyi Kvaček et Erdei and Mahonia. The family Altingiaceae is represented by a few remains of Liquidambar europaea A. Braun, which is the first occurrence of the species in Hungarian fossil floras. Later, during the middle Miocene (Sarmatian) the species became widespread in northern Hungary, and during the late Miocene (Pannonian) it predominated the riparian vegetation throughout the Carpathian Basin. The family Betulaceae is represented by one genus, Ostrya, with both leaves and involucres. From the family Fagaceae, Fagus, Quercus kubinyii and Quercus drymeja Unger were recorded. This is the first Hungarian occurrence of Q. kubinyii, which later became dominant in the Sarmatian floras of northern Hungary. The family Theaceae is represented by the rare species Ternstroemites pereger described from the coeval flora of Parschlug, and with the endemic Gordonia sp. represented by winged fruits. The presence of the family Myricaceae is evidenced by leaves of Myrica lignitum, which was a dominant element of the swamp vegetation. The family Juglandaceae played a significant role in the flora and vegetation. Besides the frequent species of Miocene floras, Engelhardia orsbergensis and E. macroptera, Carya serrifolia and other not identified species of the family, mentioned as Juglandaceae gen. et sp. 1 and sp. 2, were also recorded. The family Tiliaceae is present, with Tilia sp. and Craigia bronnii as rare accessory elements. The family Ulmaceae shows high diversity, with dominant species of Cedrelospermum: C. flichei and C. aquense. In addition, Zelkova zelkovifolia is also present, the first with such a high number of specimens in the fossil record of Hungary. The genus Ulmus is represented by Ulmus braunii and by indeterminable leaf and fruit remains of the genus. Members of the family Salicaceae are rare accessory elements, with some Populus species, among which Populus populina and $P$. balsamoides show their first occurrence in the Hungarian fossil record as rare elements. Populus populina became widespread and dominant later in the late Miocene (Pannonian) (Hably, 2013). Another species, Populus zaddachii, is a rare element, occurring in Hungary exclusively in the Miocene flora of the Mecsek Mts. The presence of the genus Populus is evidenced by its leaf, fruit and catkin remains. Members of the Buxaceae family represented by the genus Buxus are rare accessory elements, and the Rosaceae family by the genus Rosa and cf. Prinsepia serra. The latter is a rare species in Europe, first described from the flora 
of Parschlug (Kovar-Eder et al., 2004). This is the first occurrence of the species in Hungary. The Celastraceae family has few and uncertain occurrences in the Mecsek flora. The family Fabaceae is quite diverse in the flora, with some dominant and characteristic taxa. Among them, Podocarpium podocarpum dominates the flora, having mainly leaflets but also leaf and fruit (pod) remains. Nearly all fossil sites of the Miocene Mecsek flora yielded a high number of leaflets identified as Leguminosae gen. et sp. A fruit described as Leguminocarpum mecsekense is a characteristic element of the flora, and two species, Acacia parschlugiana and Leguminosites palaeogaeus, occur as rare accessory elements. The family Thymelaeaceae is represented by the rare accessory element Daphne oeningensis. Ziziphus paradisiaca is the most important species of the Rhamnaceae family; it is a dominant and characteristic element of the flora. In addition, Paliurus favonii and Berchemia multinervis are rare accessory elements. The Sapindaceae family is represented by the genus Acer. Its fruit remains outnumber leaf remains, which may be attributable to long-distance transport. From the family Anacardiaceae, Cotinus sp.and Rhus sp. are represented by a small number of specimens. The Ailanthus genus of the family Simaroubaceae is a significant element in the flora. Ailanthus confucii fruit and Ailanthus mecsekensis leaflets occur in high numbers and therefore are dominant elements of the flora. The family Ebenaceae is represented by reproductive structures described as Diospyros? microcalyx. Members of the Malvaceae family are rare elements of the flora, with Sterculia sp., Tilia sp., Craigia bronnii and leaves described as Dicotylophyllum sp. 1. The family Oleaceae is subordinate in the flora, with some fruits of cf. Fraxinus sp. The presence of the family Apocynaceae is noteworthy, with accessory remains of Nerium sp. This is the first occurrence of the genus in Hungary, but earlier it was mentioned from the flora of Parschlug, which is similar in age (Kovar-Eder et al., 2004). The family Nyssaceae is represented by leaf remains of several species (Nyssa gyoergyi sp. nov., Nyssa gergoei sp. nov., Nyssa sp. 1, cf. Nyssa div. sp. and fruits). The family Ranunculaceae is represented by Clematis csabae, and members of the family Ericaceae were recorded as leaf remains of Arbutus sp.

Among the monocots, noteworthy taxa are Smilax cf. weberi of the family Smilacaceae,
Cladiocarya sp. of the family Cyperaceae, and leaves of Palmacites of the family Arecaceae. Several monocot remains mentioned as Monocotyledonae gen. et sp. were collected, the closer affinities of which are uncertain.

Several species recorded in the Mecsek flora have their first Hungarian occurrence there. Some of them, such as Quercus kubinyii, Podocarpium podocarpum, Liquidambar europaea and Populus populina, became dominant in the middle Miocene (Sarmatian) floras, and even later during the late Miocene (Pannonian) were significant members of the riparian vegetation (Hably, 2013, 2014). In the Hungarian fossil floras, the genera Cedrelospermum and Ziziphus have their last occurrence (Cedrelospermum aquense, Cedrelospermum flichei Ziziphus paradisiaca). The first and often the only Hungarian occurrences of some species which are rare even in the whole European Miocene were recorded in the Mecsek Mts: Ternstroemites pereger, cf. Prinsepia serra, Populus zaddachii and Antholites stiriacus.

There are also endemic species such as Leguminocarpum mecsekense, Ailanthus mecsekensis, Nyssa gyoergyi sp. nov., Nyssa gergoei sp. nov., Nyssa sp. 1, Clematis csabae, Gordonia sp. and Carpolithes gergoei.

The Karpatian assemblage of the Mecsek Mts is an extremely diverse flora, with more than a hundred taxa, outnumbering most of the well-known Miocene floras of Europe.

\section{VEGETATION OF THE MECSEK MTS IN THE KARPATIAN}

The ecological requirements of plant taxa indicate the habitats that they occupied and the vegetation type in which they flourished. Based on the Mecsek fossil assemblage, four main types of vegetation can be distinguished. The swamp vegetation included arboreal, shrub and also herbaceous plants. The arboreal taxa of swamps were Glyptostrobus europaeus, Myrica lignitum and Nyssa. The shrub level was composed of Myrica, and close to open water there must have been rich stands of herbaceous monocots. Only a few remains of Salvinia, Ceratophyllaceae and Cladiocarya reflect the aquatic vegetation. Another edaphic vegetation type was riparian vegetation: Populus and Carya in low riparian habitats, and Acer and Ulmus forming arboreal vegetation in more elevated habitats. 
In wetland, Liquidambar europaea was part of the vegetation. Farther from wetlands, the zonal vegetation was composed of probably drought-tolerant subxerophytic vegetation with numerous plant taxa: Ziziphus paradisiaca, Cedrelospermum, Ailanthus, Buxus, Berberis, Mahonia, Rosa, cf. Prinsepia serra, Celastraceae, Paliurus, Cotinus, Rhus, Nerium and Arbutus. The family Fabaceae was represented in the zonal vegetation by Acacia parschlugiana, Leguminosites palaeogaeus, Leguminocarpum mecsekense, Gleditsia, Leguminosae gen. et sp. and probably Gordonia sp. Presumably the arboreal zonal vegetation was not dense but rather parkland-like; this suggestion is supported by the fact that a significant part of the arboreal species produced winged fruits or seeds. Anemochorous fruit and seed types are more frequent in open vegetation types, due to their more effective dispersal (Erdei and Hably, 2000; Erdei et al., 2012).

Influenced by local geomorphology and by other factors determining microclimate, dry habitats presumably formed, as supported by the presence of taxa such as Buxus, Berberis, Mahonia, Rosa, cf. Prinsepia serra, Celastraceae, Paliurus, Cotinus, Rhus and Nerium.

A type of vegetation with higher rainfall requirements also formed relatively close to Lake Mecsek but not in the wetlands. This vegetation included some lauraceous taxa: Daphnogene, Laurophyllum, the evergreen thermophilous Engelhardia (Juglandaceae), Palmacites and many other exotic taxa. Lianas such as Smilax and Clematis were also members of the forest vegetation. The fabaceous species Podocarpium podocarpum presumably thrived in this vegetation; it occurs in many European floras, suggesting its tolerance of a relatively broad range of climate values. In the late middle Miocene (late Sarmatian) flora of Gratkorn (Austria) it is a member of wetland vegetation (Hably and Meller, 2017), whereas in the nearly coeval Sarmatian flora of Erdóbénye (Hungary) Podocarpium is a dominant member of dryclimate vegetation (Kováts, 1856; Erdei, 1995).

\section{LATE EARLY MIOCENE CLIMATE OF THE MECSEK MTS}

Based on the climate requirements of plants, fossil floras can be applied in climate reconstructions. However, members of azonal or edaphic associations are less suitable for estimation of past climate conditions, since the occurrence of such vegetation is influenced by local (e.g. soil) factors. Most of the plant taxa of the Mecsek flora were members of zonal vegetation and thus are suitable for climate reconstruction. The ratio of "Palaeotropical" elements, which were definitely warmthdemanding members of the flora, was very high. These include Daphnogene, Laurophyllum, Lauraceae, Engelhardia, Cedrelospermum, Ailanthus, and some Fabaceae species occurring as dominant or frequent elements of the flora. Additional thermophilous elements were Ternstreomites, Smilax, Palmacites and members of Malvaceae and Theaceae.

Although edaphic associations are less suitable for climate reconstruction, these also suggest climate conditions to a certain degree. They are informative in regard to their temperature requirements, but due to the usually abundant water supply the amount and distribution of rainfall are not limiting factors.

In Magyaregregy, the swamp elements attest to warm climate. The forests composed of Glyptostrobus-Nyssa-Myrica must have formed in warm climate conditions. The Taxodium forests of Florida can be mentioned as a modern analogue. Based on the above, a warm-subtropical climate is assumed to have prevailed in the Miocene of the Mecsek Mts. According to a quantitative climate analysis (Erdei et al., 2007) of the Magyaregregy flora, the mean annual temperature was $15.6-16.6^{\circ} \mathrm{C}$, and the coldest-month and warmest-month temparatures were $5-6.2^{\circ} \mathrm{C}$ and $24.7-27.9^{\circ} \mathrm{C}$, respectively. Although that analysis was based on a preliminary, incomplete list of taxa, the estimated climate values characterize the palaeoclimate well. The reconstruction of rainfall and its distribution is more complicated. The flora represents riparian forests, subtropical laurel forests, and deciduous forests with low rainfall demand, and even taxa characteristic of dry habitats appear, including Buxus, Berberis, Mahonia, Rosa, cf. Prinsepia serra, Celastraceae, Paliurus, Cotinus, Rhus, Nerium and Arbutus; Ziziphus paradisiaca, Cedrelospermum and Ailanthus may also be mentioned here. Cedrelospermum must have had a broad climatic tolerance; it has been recorded in floras ranging from tropical or subtropical rain forests (e.g. Clarno Formation in Oregon) to seasonally dry tropical forests such as the Green River 
Formation in Colorado (Manchester, 1989), Céreste in France and the Tard Clay Formation in Hungary (Hably and Thiébaut, 2002).

This implies that rainfall was not evenly distributed, that seasonal dry periods occurred during the year, and that there were habitats with seasonal water supply. The vegetation was rather subxerophytic, not xerophytic. Periodic dry seasons were followed by rainy seasons with abundant rainfall, furnishing a water supply sufficient for extended swamp and riparian vegetation and for zonal vegetation. The estimated mean annual precipitation falls in a broad interval between 823 and $1356 \mathrm{~mm}$ (Erdei et al., 2007). This may be attributable to the presence of diverse associations, both zonal and azonal vegetation types, in the taphocoenosis.

Leaf morphology indicates both humid and dry habitat types. Large leaves and the occurrence of an attenuate leaf apex indicate warm and humid climate (e.g. Dicotylophyllum sp. 1, many specimens of Lauraceae). Dry climate conditions may be suggested by small leaves, as in Buxus, by the occurrence of narrow entiremargined leaves, as in Nerium, or by the combination of small leaf size and a toothed margin comprising teeth with attenuate or spinose apices, as in Berberis, Mahonia, Rosa, cf. Prinsepia serra and Quercus kubinyii.

\section{COMPARISON OF THE FLORA FROM THE MECSEK MTS WITH RELEVANT EARLY/MIDDLE MIOCENE SITES IN EUROPE}

\section{IPOLYTARNÓC, HUNGARY \\ (EARLY MIOCENE, OTTNANGIAN)}

A rich plant assemblage is preserved in the Gyulakeszi Rhyolite Tuff Formation (Hably, 1985a). The tuff, overlying track-bearing sandstone, yielded a single-crystal zircon U-Pb total isochron age of $17.42 \pm 0.04 \mathrm{Ma}$ and a singlecrystal laser-fusion plagioclase $40 \mathrm{Ar} / 39 \mathrm{Ar}$ age of $17.02 \pm 0.14 \mathrm{Ma}$ (uncertainties are quoted at $2 \sigma$ level) (Pálfy et al., 2007). According to Pálfy et al. (2007) the realistic age of Ipolytarnóc is $17.5 \mathrm{Ma}$. This means that the Ipolytarnóc and Magyaregregy (Mecsek Mts) floras are of nearly similar age (only 0.68 million years difference). The two floras are quite different, however. Among the shared elements are members of Lauraceae, which are dominant in
Ipolytarnóc. Other shared elements are Pinus, Magnolia, Mahonia, Engelhardia, Myrica, Daphne, Acer, Leguminosae, Smilax and various palms. In Ipolytarnóc, palaeotropical and laurophyllous elements are dominant. Except for Acer there are no Arctotertiary elements in this flora. Important species of the Ipolytarnóc flora that do not appear in the flora of the Mecsek Mts are Platanus neptuni, Pungiphyllum cruciatum and Cyclocarya cyclocarpa. On the other hand, the flora of Magyaregregy (Mecsek Mts) contains a large number of taxa, including many Arctotertiary elements, that do not occur in Ipolytarnóc: for example, Berberis andreanszkyi, Liquidambar europaea, Ostrya, Fagus, Quercus kubinyii, Q. drymeja, Ternstroemites pereger, Carya serrifolia, Cedrelospermum aquense, C. flichei, Zelkova zelkovifolia, Populus populina, P. zaddachii, P. balsamoides, Rosa, cf. Prinsepia serra, Celastraceae, Acacia parschlugiana, Leguminocarpum mecsekense, Ziziphus paradiaiaca, Paliurus favonii, Berchemia multinervis, Cotinus, Rhus, Ailanthus confucii, A. mecsekensis, Sterculia, Craigia, Nerium, Nyssa, Clematis, Arbutus, and several taxa of uncertain taxonomic position (e.g. Antholites stiriacus, Dicotylophyllum div. sp., Carpolithes div. sp.) The genus Ulmus occurs in the flora of the Mecsek Mts, represented by several organs and taxa, while in Ipolytarnóc there are no records of Ulmus in the tuff, only in the underlying sandstone beds (Ulmus pyramidalis).

The two floras clearly differ, even though they are nearly coeval and their localities are close to each other. The most plausible explanation of the floristic difference focusses on the tectonic evolution of this region. The Mecsek Mts area belongs to the Tisza tectonic unit, whereas the area of Ipolytarnóc is a member of the ALCAPA (Pannon) tectonic unit. Currently, the ALCAPA unit, and also Ipolytarnóc, occupy nearly the same (slightly more northern) latitude as the Tisza unit, including the Mecsek area. A large palaeomagnetic dataset suggests palaeopositions for the ALCAPA (Pannon) and Tisza terranes at $20 \mathrm{Ma}$ and $15 \mathrm{Ma}$ (Hably and Kázmér, 1996; Erdei et al., 2007). These data suggest that 20 million years ago the Tisza tectonic unit and the Mecsek area as well were located at much more northern latitudes than Ipolytarnóc was. Therefore the Mecsek area occupied a position with cooler climate conditions. It was also closer to stable Europe than 
the Ipolytarnóc area was, which enabled floristic exchange with the European continent. The evolution of the major tectonic units in the Pannonian domain must have played a significant role in the regional development of the flora and vegetation.

PARSCHLUG, STYRIA, AUSTRIA

(LATE EARLY/EARLY MIDDLE MIOCENE, KARPATIAN/EARLY BADENIAN)

Based on the mammals and flora, Parschlug is assigned to the Karpatian/early Badenian (Central Paratethys stages) (Kovar-Eder et al., 2004). The age of the Parschlug flora is close to that of the Mecsek flora. Several of its rare flora elements are shared by the Mecsek flora but are extremely scarce in other Miocene floras. The shared elements are Salvinia, Pinus, Glyptostrobus, Cupressus, Daphnogene, Berberis, Mahonia, Liquidambar europaea, Quercus drymeja, Ternstroemites pereger, Myrica lignitum, Engelhardia orsbergensis, E. macroptera, Tilia, Craigia bronnii, Ulmus, Cedrelospermum, Zelkova, Populus populina, Buxus, Rosa, cf. Prinsepia serra, Leguminosites hesperidum, Podocarpium podocarpum, Acacia parschlugiana, Paliurus, Berchemia multinervis, Acer, Ailanthus, Fraxinus, Nerium, Smilax and Antholites stiriacus. It is noteworthy that many drought-tolerant taxa appear in this flora. Based on the number of small-sized, probably evergreen sclerophyllous taxa, a climate less humid than in earlier and later periods, with seasonal changes in precipitation, was inferred for Parschlug (Kovar-Eder et al., 2004).

\section{CYPRIS SHALE FLORA, WESTERN BOHEMIA, CZECH REPUBLIC

(EARLY MIOCENE, OTTNANGIAN-KARPATIAN)

The flora of the Cypris Shale in western Bohemia belongs to the typical "Younger Mastixioid" plant assemblages, although Mastixiaceae are infrequent (Bůžek et al., 1996). The flora is dominated by "Palaeotropic" elements of humid subtropical climate. Elements shared with the flora of the Mecsek Mts are Salvinia, Pinus, Glyptostrobus, Tetraclinis, Magnolia, Myrica lignitum, Engelhardia orsbergensis, E. macroptera, Carya, Quercus kubinyii, Q. drymeja, Liquidambar europaea, Zelkova zelkovifolia, Celtis, Laurophyllum, Daphnogene, Podocarpium podocarpum, Populus populina, Tilia, Craigi bronnii, Buxus, Ailanthus confucii, Fraxinus, Ziziphus paradisiaca, Acer, Nyssa, Smilax and Cladiocarya. Although many taxa are shared by the Cypris Shale and Mecsek floras, these are mostly wetland elements. The subxerophytic elements characteristic of the Mecsek flora are totally missing from the Cypris Shale. At the same time, some taxa occurring in the Cypris Shale flora are missing from the Mecsek flora (e.g. Platanus neptuni, Alnus div. sp., Sassafras). The dominant occurrence of Ziziphus paradisiaca is noteworthy, since it is a relatively rare element of European Miocene floras. The flora of the Cypris Shale was fossilized in Miocene lignite-bearing sediments, indicating ecological and climatic conditions different from those of the Mecsek Mts.

\section{KYMI, EVIA, GREECE (MIDDLE EARLY MIOCENE)}

This flora is comparable in age to the Karpatian flora of the Mecsek Mts. The flora was published by Unger (1867) and revised by Kvaček (in Velitzelos, ed. 2002). The shared elements with the Karpatian flora of the Mecsek Mts are Cupressus, Glyptostrobus europaeus, Pinus, Laurophyllum, Daphnogene, Myrica, Quercus drymeja, Zelkova zelkovifolia, Populus populina, Berberis, Ziziphus paradisiaca, Leguminosae, Diospyros? microcalyx, Acer, Rosa, Antholites, Leguminocarpon, cf. Prinsepia serra as ?Berberis, and several unidentified elongated narrow leaves mentioned as Dicotylophyllum. The flora of Kymi is less diverse than the flora of Magyaregregy (Mecsek Mts). Several Alnus species that are absent in the flora of Magyaregregy occur in the flora of Kymi. The similarity of these floras is manifested mainly in the occurrence of xerophytic elements.

\section{ACKNOWLEDGEMENTS}

It rarely happens that collecting activity occurs in the same area over a period of more than two decades. I am grateful first of all to my family, my husband Dr György Szakmány, my sons Dr Gergó Szakmány and Dr Csaba Szakmány, and our geologist colleague and friend Dr Sándor Józsa for the unforgettable summers when they helped me collecting in Magyaregregy. The result of their hard work is the collection comprising nearly 10000 specimens, large enough to represent the Miocene flora of the Mecsek Mts and to provide a basis for vegetation analyses. In the last few years, collections made by Dr Krisztina Sebe during her geological field trips enriched the already enormous collection and even provided unexpected new results. 
I thank Dr István Rácz for taking photographs of the specimens, and Agnieszka Sojka for making the photoplates. Many thanks to my colleague Dr Boglárka Erdei for fruitful discussions. I am grateful to the reviewers (Prof. Johanna Kovar-Eder, Prof. Zlatko Kvacek) for their suggestions and thorough discussions. The research was supported by the National Research, Development and Innovation Office (NKFIH K108664)

\section{REFERENCES}

Akhmetiev, M., Walther, H., Kvaček, Z., 2009. Midlatitude Palaeogene floras of Eurasia bound to volcanic settings and palaeoclimatic events - experience obtained from the Far East of Russia (Sikhote-Alin') and Central Europe (Bohemian Massif). Acta Musei Nationalis Pragae, B. Historia Naturalis 65(3-4), 61-129.

Andreánszky, G., 1955. Új növényfajok Magyaregregy alsó-helvéti emeletéból. (Neue Pfalnzenarten aus der unterhelvetischen Stufe von Magyaregregy). In: Andreánszky, G., Kovács, É. (ed.), A hazai fiatalabb harmadidôszaki flórák tagolása és ökológiája. (Gliederung und ökologie der jüngeren Tertiärfloren Ungarns). Annales Instituti Publici Geologiae Hungarici 44(1), 14-16, 152-153.

Andreánszky, G., 1959. Die Flora der sarmatischen Stufe in Ungarn. Akadémiai Kiadó, Budapest, 360 pp.

Andreánszky, G., 1962. Contributions à la connaissance de la Flore de l'oligocene superieur de la briqueterie Wind prés d'Eger (Hongrie Septentrionale). Acta Botanica Hungarica 8(3-4), 219-239.

Andreánszky, G., 1966. The Upper Oligocene Flora of Hungary. Analysis of the site at the Wind Brickyard, Eger. Studia Biologica Hungarica 5, 1-151.

Barabás, A., 2010. A délkeletdunántúli hidrogenetikus uránérctelepek földtani környezete és összehasonlító értékelésük. PTE, Manuscript, $\mathrm{PhD}$ thesis, $170 \mathrm{pp}$.

Barabás, A., 2011. A Mecsek harmadidôszaki rétegsora és fejlődéstörténete. In: Erôss, A., Gyốri O., Kovács-Lukoczki G., Páll-Somogyi K., Tóth J. (eds), Mecsek földtani terepgyakorlat, kirándulásvezetó, Magyarhoni Földtani Társulat, pp. 44-49.

Báldi-Beke, M., 1963. Coccolithophorida vizsgálatok a mecseki miocénben. Földtani Intézet évi jelentése 1961-ról, pp. 161-163.

Berger, W., 1952. Die altpliozäne Flora der CongerienSchichten von Brunn-Vösendorf bei Wien. Palaeontographica, Abt. B 92, 79-121.

Berger, W., 1955. Die altpliozäne Flora des Laaerberges in Wien. Palaeontographica, Abt. B 97, 81-113.

Braun, A., 1836. In: Buckland, W. (ed.), Geology and Mineralogy considered with reference to Natural Theology, 1. London, pp. 510-514.

Brongniart, A., 1822. Sur la classification et la distribution des végétaux fossiles en géneral et sur ceux des terrains de sédiment superieur en particulier. Mémoires du Muséum d'histoire naturelle 8, 203-240.

Brongniart, A., 1828. Notice sur les plantes d'Armissanpres Nar-bonne. Annales des sciences naturelles, ser. I, 15, 43-51.

Brongniart, A., 1833. Notice sur une Conifere fossile du terrain d'eau douce de l'ile d'Iliodroma. Annales des sciences naturelles 30, 168-176.

Bronn, H.G., 1837. XLVII Tafeln mit Abbildungen zur Lethäa Geognostica. E. Scharzerbart's VerlagBuchhandlung, Stuttgart, pp. 16.

Bronn, H.G., 1838. Lethaea Geognostica II. das Kreide und Molasse-Gebirge enthaltend. E. Scharzerbart's Verlag-Buchhandlung, Stuttgart, pp. 545-1346.

Budai, T., Csillag, G., Kercsmár, Z., Selmeczi, I., Sztanó, O., 2015. Surface geology of Hungary. In: Zs., Kercsmár (ed.), Explanatory notes to the Geological map of Hungary (1:500,000). Budapest: Geological and Geophysical Institute of Hungary.

Budantsev, L., (ed) 2005. Fossil flovering plants of Russia and adjacent countries. Vol. 4. Nyctaginaceae-Salicaceae, Mosquae-Petropoli, 184 pp., 140 Plate.

Bůžek, Č., 1971. Tertiary Flora from the Northern Part of the Pětipsy Area (North-Bohemian Basin). Rzpravy Ústredniho ústavu geologického 36, 1-118.

Bůžek, Č., Holý, F., Kvaček, Z., 1976. Tertiary flora from the Volcanogenic Series at Markvartice and Veselíčko near Česká Kamenice (České středohoří Mts.). Sborník geologických věd, Paleontologie 18, 69-132.

Bůžek, Č., Dvořák, Z., Kvaček, Z., Prokš, M., 1992. Tertiary vegetation and depositional environments of the "Bílina delta" in the North-Bohemian browncoal basin. Časopis pro mineralogii a geologii 37, 117-134.

Bůžek, Č., Holý, F., Kvaček, Z., 1996. Early Miocene flora of the Cypris Shale (Western Bohemia). Acta Musei Nationalis Pragae, B 52(1-4), 1-72.

Chikán, G., 1991. A Nyugati-Mecsek kainozóos képződményei. (Die känozoischen Ablagerungen des westlichen Mecsekgebirges). Annales Instituti Publici Geologiae Hungarici 72, 1-281.

Christensen, E.F., 1975. The Søby Flora: Fossil plants from the Middle Miocene delta deposits of the Søby-Fasterholt area, Central Jutland, Denmark. Part. I. Reitzels Forlag, København, 41 pp.

Cziffery-Szilágyi, G., 1955. Adatok az erdóbényei szarmata flóra ismeretéhez. (Beiträge zur Kenntnis der sarmatischen Flora von Edóbénye). In: Andreánszky, G., Kovács, É. (eds), A fiatalabb harmadidôszaki flórák tagolása és ökológiája. (Gliederung und ökologie der jüngeren Tertiärfloren Ungarns). Annales Instituti Publici Geologiae Hungarici 44(1), pp. 23-32, 159-165.

Denk, T., Velitzelos, D., Güner, T.H., Bouchal, J.M., Grímsson, F., Grimm, G., W. 2017. Taxonomy and palaeoecology oft wo widespread western Eurrasian sclerophyllous oak species: Quercus drymeja 
Unger and $Q$. mediterranea Unger. Review of Paleobotany and Palynology 241, 98-128.

Dilcher, D., 1974. Approaches to the identification of Angiosperm leaf remains. The Boanical Review 40(1), 1-145.

Ellis, B., Daly, D.C., Hickey, L.J., Johnson, K.R., Mitchell, J.D., Wilf, P., Wing, S.L., 2009. Manual of leaf architecture. New York Botanical Garden, $190 \mathrm{pp}$.

Engelhardt, H., 1881. Über Pflanzenreste aus den Tertiärablagerungen von Liebotitz und Putschirn. Sitz. Ber. Isis Dresden, pp. 78-86.

Engelhardt, H., 1891. Über die Flora der über den Braunkohlen befindlichen Tertiärschichten von Dux. N. Acta Leop. Carol. Akad. 57, 129-219.

Erdei, B., 1995. The Sarmatian flora from ErdóbényeLigetmajor, NE Hungary. Annales Historico-naturales Musei Nationalis Hungarici 87, 11-33.

Erdei, B., Hably, L., 2000. Paleoecological and taphonomical implications of winged fruits and seeds in the Tard Clay Flora (Lower Oligocene, Hungary). The sixth Conference of the International Organization of Palaeobotany, Abstracts (IOPC-VI) China, p. 33.

Erdei, B., Hír, J., 2002. Vegetation and climate reconstruction of Sarmatian (Middle Miocene) sites from $\mathrm{NE}$ and W Hungary. Acta Universitatis CarolinaeGeologia 46(4), 75-84.

Erdei, B., Magyari, E., 2011. Late Miocene plant remains from Bükkábrány, Hungary. Studia Botanica Hungarica 42, 135-151.

Erdei, B., Hably, L., Kázmér, M., Utescher, T., Bruch, A., 2007. Neogene flora and vegetation development of the Pannonian domain in relation to palaeoclimate and palaeogeography. Palaeogeography, Palaeoclimatology, Palaeoecology 253, 131-156.

Erdei, B., Dolezych, M., Hably, L., 2009. The buried Miocene forest at Bükkábrány, Hungary. Review of Paleobotany and Palynology 155, 69-79.

Erdei, B., Utescher, T., Hably, L., Tamás, J., RothNebelsick, A., Grein, M., 2012. Early Oligocene Continental climate of the Palaeogene Basin (Hungary and Slovenia) and the surrounding area - a complex approach. Turkisch Journal of Earth Sciences 21, 153-186.

Ettingshausen, C., 1851. Die Tertiärfloren der Österreichischen Monarchie. 1. Die Tertiäre Flora der Umgebung von Wien. Abhandlungen der KaiselichKöniglichen Geologischen Reichsanstalt 1(1), 7- 36.

Ettingshausen, C.V., 1852. Fossile Pflanzenreste aus dem trachytischen Sandstein von Heiligenkreutz bei Kremnitz. Abhandlungen der KaiserlichKöniglichen Geologischen Reichsanstalt 1(5), 1-14.

Ettingshausen, C.V., 1853. Die tertiäre Flora von Häring in Tirol. Abhandlungen der KaiselichKöniglichen Geologischen Reichsanstalt 2, 1-118.

Ettingshausen, C.V., 1866. Die fossile Flora des Tertiarbeckens von Bilin I. Denkschriften der Kaiserlichen Akademie der Wissenschaften / Mathematisch-Naturwissenschaftliche Classe 26, 1-98.
Ettingshausen, C.V., 1868. Die fossile Flora des Tertiarbeckens von Bilin II. Denkschriften der Kaiserlichen Akademie der Wissenschaften / Mathematisch-Naturwissenschaftliche Classe 29, 1-110.

Ettingshausen, C.V., 1869. Die fossile Flora des Tertiarbeckens von Bilin III. Denkschriften der Kaiserlichen Akademie der Wissenschaften / Mathematisch-Naturwissenschaftliche Classe 28, 191-242.

Ettingshausen, C.V., 1888. Die fossile Flora von Leoben in Steiermark. 1, 2. Theil. Denkschr. kaiserl. Akad. Wiss. Math.-naturwiss. Cl. 54, 261-318, $319-384$.

Ettingshausen, C.V., 1890. Die fossile Flora von Schönegg bei Wies in Steiermark. 1. Theil. Denkschriften der Kaiserlichen Akademie der Wissenschaften / Mathematisch-Naturwissenschaftliche Classe 57, 61-112.

Fernandez Marrón, M.T., 1971. Estudio paleoecológico y revisión sistemática de la flora fósil del Oligoceno español. Publicaciones de la Facultad de Ciencias, Universidad Complutense de Madrid, pp.177.

Fischer, O., Hably, L., 1991. Pliocene flora from the alginite at Gérce. Annales historico-naturales Musei nationalis hungarici 83, 25-47.

Givulescu, R., 1962. Die fossile Flora von Valea Neagra, Bezirk Crisana, Rumänien. Palaeontographica, Abt. B 110, 128-187.

Givulescu, R., 1990. Flora fosilaa miocenului superior de la Chiuzbaia. Editura Academiei Romane, Bucuresti, 235 pp.

Givulescu, R., 1998. Mahonia sp. (n. Sp. ?) une nouvelle Mahonia du Pannonien inférieur de Valea Crisului (Bihor Roumanie). Studia Universitatis Babeș-Bolyai, Geol. 43(2), 3-5.

Göppert, H.R., 1855. Die tertiäre Flora von Schossnitz in Schlesien. Görlitz, 52 pp.

Gyalog, L., (ed.) 1996. A földtani térképek jelkulcsa és a étegtani egységek rövid leírása (Legend of the geological maps and a brief description of lithostratigraphic units). Occasional Papers of the Geological Institute of Hungary 187, 171, Budapest.

Gyalog, L., Budai, T., (eds) 2004. Javaslatok Magyarország földtani képzốdményeinek litosztratigráfiai tagolására (Suggestions for the lithostratigraphic classification of geological formations of Hungary). Annual Report of the Geological Institute of Hungary on 2002, pp. 195-232.

Hably, L., 1979. Some Data to the Oligocene Flora of the Kiscellian Tard Clay, Hungary. Annales historico-naturales Musei Nationalis Hungarici 71, 33-53.

Hably, L., 1982. Egerian (Upper Oligocene) Macroflora from Verốcemaros (Hungary). Acta Botanica Hungarica 28(1-2), 91-111.

Hably, L., 1985a. Early Miocene Plant fossils from Ipolytarnóc, N. Hungary. Geologica Hungarica Ser. Palaeontologica 45, 73-256.

Hably, L., 1985b. New data to the Eocene flora of Hungary. Annales historico-naturales Musei nationalis hungarici 77, 25-33. 
Hably, L., 1988. Egerian fossil flora from Kesztölc, NW Hungary. Studia Biologica Hungarica 20, 33-61.

Hably, L., 1990. Egerian plant fossils from Vértesszólôs, NW Hungary. Studia Biologica Hungarica 22, 3-78.

Hably, L., 1992a. The flora of Tihany-Fehérpart (faciostratotype of the Intra-Carpathian Pontian), West Hungary. Geophytology 22, 199-205.

Hably, L., 1992b. Distribution of legumes in the Tertiary of Hungary. In: Herendeen, P.S., Dilcher, D.L. (eds), Advances in Legume Systematics Part 4. The Fossil Record, The Royal Botanical Gardens, Kew, pp. 169-187.

Hably, L., 1992c. Early and late Miocene Floras from the Iharosberény-I and Tiszapalkonya-I Boreholes. Fragmenta Mineralogica et Palaeontologica 15, $7-40$.

Hably, L., 1994. Egerian plant fossils from Pomáz, Hungary. Fragmenta Mineralogica et Palaeontologica 17, 5-70.

Hably, L., 2001. Fruits and leaves of Ailanthus Desf. from the Tertiary of Hungary. Acta Palaeobotanica 41, 207-219.

Hably, L., 2002. The Middle Miocene flora of Magyaregregy - as shown by a study of recent collections. 6th European Paleobotany-Palynology Conference, August 29-September 2, 2002, Athens, Greece, Program Book of Abstracts, pp. 91-92.

Hably, L., 2013. The Late Miocene flora of Hungary. Geologica Hungarica ser. Palaeontologica 59, 1-175.

Hably, L., 2014. Paleogén és neogén flóra- és vegetáció változások magyarországi lelóhelyek alapján. Kanitzia Köszöntô. Tanulmányok Kovács J. Attila 70. születésnapja tiszteletére. (in Hungarian), pp. 61-96.

Hably, L., Erdei, B., 2019. Winged seeds of Theaceae from the lower Miocene (Karpatian) of the Mecsek Mts, Hungary. - in press.

Hably, L., Fernandez Marron, M.T., 1998. Comparison of the Oligocene floras of the Tethyan and CentralParatethyan areas on the basis of Spainish and Hungarian macroflora. Tetrtiary Research 18(3-4), 67-76.

Hably, L., Kázmér, M., 1996. Short-term floristic changes due to terrane displacement in the Miocene of Hungary. I.O.P.C. V-1996, Abstracts, Santa Barbara, California, USA.

Hably, L., Kovar-Eder, J., 1996. A representative leaf assemblage of the Pannonian Lake from Dozmat near Szombathely (Western Hungary), Upper Pannonian, Upper Miocene. In: Advances in AustrianHungarian Joint Geological Research. Budapest, pp. 69-81.

Hably, L., Kvaček, Z., 1997. Early Pliocene plant megafossils from the volcanic area in West Hungary. Studia Naturalia 10, 5-151.

Hably, L., Meller, B., 2017. Sarmatian wetlands at the NW margin of the Pannonian Basin system (Gratkorn, Styrian Basin, Austria, late middle Miocene). Part 1. The leaf record. Palaeontographica, Abt. B 295(4-6), 135-165.
Hably, L., Sebe, K., 2016. A late Miocene termophilous flora from Pécs-Danitzpuszta, Mecsek Mts., Hungary. Neues Jahrbuch für Geologie und Paläontologie 279(3), 261-271.

Hably, L., Thiébaut, M., 2002. Revision of Cedrelospermum (Ulmaceae) fruits and leaves from the Tertiary of Hungary and France. Palaeontographica, Abt. B 262, 71-90.

Hably, L., Erdei, B., Kvaček, Z., 2001. 19 th $^{\text {century's }}$ palaeobotanical types and originals of the Hungarian Natural History Museum. Studia Naturalia 13, 1-235.

Hably, L., Schweitzer, F., Szeberényi, J., 2010. The hot spring deposits near Magyarkút and their paleobotanical analysis (Börzsöny Mountains, Hungary). Hungarian Geographical Bulletin 59(1), 3-16.

Hably, L., Erdei, B., Sebe, K., 2019. Thermophilous elements from the late Miocene flora of Pécs-Danitzpuszta (Mecsek Mts., Hungary) - confirmed by cuticular analysis. Studia Botanica Hungarica 50(1), 9-17.

Hámor, G., 1964. AK-i Mecsek miocén képzódményeinek vizsgálata. Földt. Int. Évi jel. 1961-ról, pp. 109116. (in Hungarian)

Hámor, G., 1970. Das Miozän des östlichen MecsekGebirges (Miocene of the Eastern Mecsek Mts.). Annals of the Hungarian Geological Institute 53(1), 371.

Heer, O., 1855. Die tertiäre Flora der Schweitz I, 1-117, Winterthur.

Heer, O., 1856. Die tertiäre Flora der Schweitz II, 1-107, Winterthur.

Heer, O., 1859. Die tertiäre Flora der Schweitz III, 1-377, Winterthur.

Herendeen, P.S., 1992a. A re evaluation of the fossil genus Podogonium Heer. In: Herendeen, P.S., Dilcher, D.L. (eds), Advances in legume systematics, part 4, the fossil record, pp. 3-18.

Herendeen, P.S., 1992b. Podocarpim podocarpum comb. nov., the correct name for Podogonium knorrii Heer, nom. illegit. (fossil Fabaceae). Taxon 41, 731-736.

Horváth, E., 1971-72. Beiträge zur Kenntnis der pliozänen Flora westungarns. Savaria, Vas megyei múzeumok értesítóje, 5-6, 23-73.

Iljinskaja, I.A., 1968. Neogene floras of the Transcarpathian region of the U.S.S.R. (in Russian). Nauka, Leningrad, $121 \mathrm{pp}$.

Jähnichen, H., Mai, D., Walther, H., 1977. Blätter und Früchte von Engelhardia Les. Ex Bl. Juglandaceae aus dem europäischen Tertiär. Feddes Repertorium 88(5-6), 323-363.

Jia, L.-B., Manchester, S.R., Su, T., Xing, Y-W., Chen, W-Y, Huang, Y-J., Zhou, Z-K., 2015. First occurrence of Cedrelospermum (Ulmaceae) in Asia and its biogeographic implications. Journal of Plant Research 128, 747-761.

Józsa, S., Szakmány, Gy., 2011. A mecseki miocén durvatörmelékes összlet "Adjátok vissza a hegyeimet" - Eltúnt hegységek nyomában. In: Erôss, A., Gyốri O., Kovács-Lukoczki G., Páll-Somogyi K., 
Tóth J. (eds), Mecsek földtani terepgyakorlat, kirándulásvezetô, Magyarhoni Földtani Társulat, pp. 50-57. (in Hungarian)

Józsa, S., Szakmány, Gy., Máthé, Z., Barabás, A., 2009. A Mecsek és környéke miocén konglomerátum összletek felszíni elterjedése és a kavicsanyag összetétele (Surface distribution and material of Miocene conglomerates in the Mecsek Mts. and surroundings). In: M. Tóth T. (ed), Magmás és metamorf képzódmények a Tiszai Egységben (Igneous and metamorphic formations in the Tisza Unit) 2009. GeoLitera, Szeged, pp. 195-217. (in Hungarian)

Knobloch, E., 1961. Die oberoligozäne Flora des Pirskenberges bei Šluknov in Nord-Böhmen. Sborník Ústředního ústavu geologického, Paleontologie 26, 241-315.

Knobloch, E., 1969. Tertiäre Floren von Mähren. Brno, $201 \mathrm{pp}$.

Knobloch, E., 1986. Die Flora aus der Oberen Süsswassermolasse von Achldorf bei Vilsbiburg (Niederbayern). Documenta naturae 30, 14-48.

Knobloch, E., 1994. Erkentnisse zur oligozänen Flora von Bechlejovice bei Decin. Vestnik Ceského Geologického Ustavu 69, 63-67.

Knobloch, E., 1998. Der Pliozäne Laubwald von Willershausen am Harz (Mitteleuropa). Documenta naturae 120, 1-302.

Knobloch, E., Kvaček, Z., 1976. Miozäne Blätterfloren vom Westrand der Böhmischen Masse. Rozpravy Ústredniho Ústavu Geologického 42, 1-131.

Knobloch, E., Kvaček, Z., 1996. Miozäne Floren der südböhmischen Becken. Sborník geologických věd, Paleontologie 33, 39-77.

Knobloch, E., Velitzelos, E., 1986. Die obermiozäne Flora von Likudi bei Elassona/Thessalien, Griechenland. Documenta naturae 29, 5-20.

Kolakovski, A.A., 1964. A Pliocene flora of the Kodor river. Akademia Nauk Gruzinskoj SSR, Suhumi, 208 pp.

Konrád, Gy., Sebe, K., 2010. Fiatal tektonikai jelenségek új észlelései a Nyugat-Mecsekben és környezetében. Földtani Közlöny 140(2), 445-468 (in Hungarian).

Konrád, Gy., Sebe, K., 2011. A Délkelet-Dunántúl földtani fejlődéstörténete. In: Erôss, A., Gyoóri O., Kovács-Lukoczki G., Páll-Somogyi K., Tóth J. (eds), Mecsek földtani terepgyakorlat, kirándulásvezetó, Magyarhoni Földtani Társulat, pp. 6-12 (in Hungarian).

Korecz-Laky, I., 1968. A Keleti-Mecsek miocén foraminiferái. (Miozäne Foraminiferen des östlichen Mecsek-Gebirges). Annales Instituti Publici Geologiae Hungarici 52(1), 1-200.

Kovács, Á., Sebe, K., Magyar, I., Szurominé Korecz, A., Kovács, E., 2018. Pannóniai üledékképződés és szerkezeti mozgások az Északi-pikkely (Kelet-Mecsek) területén (Upper Miocene sedimentation and tectonics in the Northern Imbricate Zone (Eastern Mecsek Mts, SW Hungary)). Földtani Közlöny 148(4), 327-340.
Kovács, É., 1959. Note sur la Flore Éocéne de Lábatlan (Transdanubie du Nord). Annales Universitatis Scientiarum Budapestinensis de Lorando Eötvös Nominatae, Sectio Biologica 2, 135-140.

Kovar-Eder, J., 1988. Obermiozäne (Pannone) Floren aus der Molassenzone Österreichs. Beiträge zur Paläontologie von Österreich 14, 19-121.

Kovar-Eder, J., Krainer, B., 1990. Faziesentwicklung und Florenabfolge des Aufslusses Wörth bei Kirchberg/Raab (Pannon, Steirisches Becken). Annalen des Naturhistorischen Museums in Wien 91, 7-38.

Kovar-Eder, J., Krainer, B., 1991. Flora und Sedimentologie der Fundstelle Reith bei Unterstorcha, Bezirk Feldbach in der Steiermark (Kirchberger Schotter, Pannonium C, Miozän), Jahrbuch der Geologischen Bundesanstalt 134/4, 737-771.

Kovar-Eder, J., Schwarz, J., Wójcicki, J., 2002. The predominantly aquatic flora from Pellendorf, Lower Austria, Late Miocene, Pannonian - a systematic study. Acta Palaeobotanica 42(2), 125-151.

Kovar-Eder, J., Kvaček, Z., Ströbitzer-Hermann, M., 2004. The Miocene Flora of Parschlug (Styria, Austria) - Revision and Synthesis. Annalen des Naturhistorischen Museums in Wien $105 \mathrm{~A}$, 45-159.

Kováts, Gy., 1851. Fossile Flora von Erdõbénye. Jahrbuch der Kaiserlich Königlichen Geologischen Reichsanstalt 2(2), 178.

Kováts, Gy., 1856. Fossile Flora von Erdóbénye. Arbeiten der geologischen Gesellschaft für Ungarn 1, $1-37$.

Köhler, J., Uhl, D., 2014. Die Blatt-und Karpoflora der oberoligozänen Fossillagerstätte Enspel (Westerwald, Rheinland-Pfalz, W-Deutschland). Mainzer Naturwissenschaftliches Archiv 35, 1-87.

Kräusel, R., 1820. Nachträge zur tertiarflora Schlesiens I. Jahrbuch der königlich preussischen geologischen Landesanstalt 39(3), 329-417.

Kräusel, R., 1821. Nachträge zur Tertiärflora Schlesiens. III. Über einige originale Göppert's und neuere Funde. Jb. Preuss. Landesanst. f. d. J. 1919, 40(3), 363-433.

Kräusel, R., Weyland, H., 1950. Kritische Untersuchungen zur Kutikularanalyse tertiär Blätter I. Palaeontographica B 91, 7-92.

Kristofovich, A.N., Baikovskaja, T.N., 1965. Sarmatskaja flora Krünki. Nauka, Moskva-Leningrad, $135 \mathrm{pp}$.

Kvaček, Z., 1971. Fossil Lauraceae in the stratigraphy of the North-Bohemian Tertiary. Sbornik Geologickych Věd, ̌̌. Paleont. 13, 47-86.

Kvaček, Z., 1989. Fosilní Tetraclinis Mast. (Cupressaceae). Časopis Národního Muzea v Praze, řada přirodovědná 155(1-2), 45-54.

Kvaček, Z., 2004. Early Miocene records of Craigia (Malvaceae s. 1.) in the Most Basin, North Bohemia - whole plant approach. Journal of the Czech Geological Society 49(3-4), 161-171.

Kvaček, Z., 2006. Fossil fruits of Reeveisa (Malvaceae, subfam. Helicteroideae) and associated plant 
organs (seeds, foliage) from the Lower Miocene of North Bohemia (Czech Republic). Neues Jahrbuch für Geologie und Paläontologie. Monatshefte 7, 431-448.

Kvaček, Z., Bůžek, Č., 1972. Nyssa-leaves from the Tertiary of Central Europe. Časopis pro mineralogii a geologii, roč. 17(4), 373-382.

Kvaček, Z., Bůžek, Č., 1994. A new Early Miocene Mahonia Nutt. (Berberidaceae) of Europe. Věstník Českého geologického ústavu 69(3), 59-62.

Kvaček, Z., Erdei, B., 2001. Putative proteaceous elements of the Lomatites-type reinterpreted as new Berberis of the European Tertiary. Plant Systematics and Evolution 226, 1-12.

Kvaček, Z., Hurník, S., 2000. Revision of Early Miocene plants preserved in Baked Rocks in the North Bohemian tertiary. Acta Musei Nationalis Pragae, series B, Historia Naturalis 56(1-2), 1-48.

Kvaček, Z., Teodoridis, V., 2011. The Late Eocene flora of Kučlín near Bílina in North Bohemia revisited. Acta Musei Nationalis Pragae, series B, Historia Naturalis 67(3-4), 83-144.

Kvaček, Z., Walther, H., 1974. Bemerkenswerte und seltene cinnamomoide Blätter aus dem Grenzbereich des Oligo-Miozäns Mitteleuropas. Abhandlungen des Staatlichen Museums für Mineralogie und Geologie zu Dresden 21, 197-221.

Kvaček, Z., Walther, H., 1995. The Oligocene volcanic flora of Suletice-Berand near Ústí nad Labem, North Bohemia - a review. Acta Musei Nationalis Pragae, B. Historia Naturalis 50(1-4), 25-54.

Kvaček, Z., Walther, H., 1998. The Oligocene volcanic flora of Kundratice near Litoměřice, České Středohoří volcanic complex (Czech Republic) - a review. Acta Musei Nationalis Pragae, Series B, Natural History 54(1-2), 1-42.

Kvaček, Z., Walther, H., 2004. Oligocene Flora of Bechlejovice at Děčín from the Neovolcanic Area of the České St ředohoří Mountains, Czech Republic. Acta Musei Nationalis Pragae, Series B, Natural History 60(1-2), 9-60.

Kvaček, Z., Bůžek, Č., Manchester, S., 1991. Fossil fruits of Pteleaecarpum Weyland - Tiliaceous, not Sapindaceous. Botanical Gazette 152(4), 522-523.

Kvaček, Z., Hably, L., Szakmány, Gy., 1994. Additions to the Pliocene flora of Gérce (Western Hungary). Földtani Közlöny 124(1), 69-87.

Kvaček, Z., Manchester, S., Schorn, H.E., 2000. Cones, Seeds, and Foliage of Tetraclinis Salicornioides (Cupressaceae) from the Oligocene and Miocene of Western North America: A Geographic Extension of the European Tertiary Species. International Journal of Plant Sciences 161(2), 331-344.

Kvaček, Z., Manchester, S., Zetter, R., Pingen, M., 2002a. Fruits and seeds of Craigia bronnii (Malvaceae - Tilioideae) and associated Lower buds from the late Miocene Inden Formation, Lower Rhine Basin, Germany. Review of Palaeobotany and Palynology 119, 311-324.
Kvaček, Z., Velitzelos, D., Velitzelos, E., 2002b. Late Miocene flora of Vegora Macedonia N. Greece. Athens, $175 \mathrm{pp}$.

Kvaček, Z., Teodoridis, V., Roiron, P., 2011. A forgotten Miocene mastixioid flora of Arjuzanx (Landes, SW France). Palaeontographica, Abt. B 285, 3-111.

Magyar, I., Geary, D.H., Müller, P., 1999. Paleogeographic evolution of the Late Miocene Lake Pannon in Central Europe. Palaeogeography, Palaeoclimatology, Palaeoecology 147, 151-167.

Mai, H.D., 1983. Studien an Endocarpien europäischen und westasiatischer Arten der Gattung Acer L. (Aceraceae). Gleditschia 10, 37-57.

Mai, H.D., 1984. Die Endocarpien bei der Gattung Acer L.(Aceraceae) - eine biosystematische Studie. Gleditschia 11, 17-46.

Mai, H.D., Walther, H., 1978. Die Floren der Haselbacher Serie im Weisselster-Becken (Bezirk Leipzig, DDR). Abhandlungen des Staatlichen Museums für Mineralogie und Geologie zu Dresden 28, 1-101.

Manchester, S.R., 1989. Attached reproductive and vegetative remains of the extinct American-European genus Cedrelospermum (Ulmaceae) from the early Tertiary of Utah and Colorado. American Journal of Botany 76(2), 256-276.

Manchester, S.R., 1994. Inflorescence bracts of fossil and extant Tilia in North America, Europe, and Asia: Patterns of morphologic divergence and biogeographic history. American Journal of Botany 81(9), 1176-1185.

Meller, B., Kovar-Eder, J., Zetter, R., 1999. Lower Miocene leaf, palynomorph, and diaspore assemblages from the base of the lignite-bearing sequence in the opencast mine Oberdorf, N Voitsberg (Styria, Austria) as an indication of "Younger Mastixioid" vegetation. Palaeontographica, Abt. B 252(5-6), 123-179.

Meyer, H.W., Manchester, S.R., 1997. The Oligocene Bridge Creek Flora of the John Day Formation, Oregon. University of California press, Geological Sciences 141, 1-195.

Mihajlovic, D., 1985. Paleogene fossil flora of Serbia. Des Annales Géologiques de la Péninsule Balkanique 49, 229-434.

Miklós, D., 2018. A Nyugat-Mecsek (Borjúsréti-völgy) kora-miocén rétegsorának komplex petrográfiai vizsgálata. ELTE, Manuscript, Diplomamunka MSc, 136 pp. (in Hungarian).

Nagy, E., 1969. A Mecsek hegység miocén rétegeinek palynológiai vizsgálata (Palynological elaborations the Miocene layers of the Mecsek Mountains). Annales Instituti Publici Geologiae Hungarici 52(2), 237-537.

Nagymarosy, A., 1980. A magyarországi bádenien korrelációja nannoplankton alapján. Földtani Közlöny 110(2), 206-245.

Nagymarosy, A., 1985. The correlation of the Badenian in Hungary based on Nannoflora. Annales of the Eötvös University Budapest, Sect. Geol. 25, 33-86. 
Pantic, N.K., 1956. Biostratigraphie des flores tertiaires de Serbie. Annales Géologiques De La Péninsule Balkanique 24, 199-321.

Pálfalvy, I., 1953. Középsô-miocén növények Magyaregregy környékéról. (Plantes Miocenes mayennes des environs de Magyaregregy). Magyar Állami Földtani Intézet évi jelentése 1950-ról, pp. 175-180.

Pálfalvy, I., 1961. Új növények a mecseki középsô-miocén rétegekból. (Neue Pflanzenarten aus den mecseker mittleren miozänen Schichten). Magyar Állami Földtani Intézet évi jelentése 1957-ról, pp. 401-415.

Pálfalvy, I., 1964. A mecsekhegység helvét - torton flórája. (Die Helvetisch-Tortonische Flora des Mecsek-Gebirges). Magyar Állami Földtani Intézet évi jelentése 1961-ról, pp. 185-199.

Pálfalvy, I., 1965. Növénymaradványok az abaligeti Kiskóhegy felsóhelvéti halpikkelyes agyagösszetételból. (Pflanzenreste aus dem oberhelvetischen fischengruppen-tonkomplex des Kiskó-berges bei Abaliget [Mecsek-Gebirge, Südungarn]). Magyar Állami Földtani Intézet évi jelentése 1963-ról, pp. 169-175.

Pálfalvy, I., 1967. Növénymaradványok az abaligeti Kiskóhegy felsóhelvéti halpikkelyes agyagösszletéból. (Pflanzenreste aus dem Oberhelvetishen Fischschuppen-Tonkomplex des Kiskó-Berges bei Abaliget (Mecsek-Gebirge, Südungarn). Magyar Állami Földtani Intézet évi jelentése 1965-ról, pp. 169-175.

Pálfy, J., Mundil, R., Renne, P.R., Bernor, R.L., Kordos, L., Gasparik, M., 2007. U-Pb and 40Ar/39Ar dating of the Miocene fossil track site at Ipolytarnóc (Hungary) and its implications. Earth and Planetary Science Letters 258, 160-174.

Pilar, G., 1883. Flora fossilis Susedana. Apud Leopoldum Hartman Bibliopolam Academiae Slav. Merid., Zagrabiae, 163 pp.

Pimenova, I.V., 1954. Sarmatskaja flora Amvrosievski. Trudy Geol. Inst. Akad. Nauk. SSSR, Kiev 8, 1-98.

Pop, E., 1936. Flora Pliocenica dela Borsec. (Die Pliozäne Flora von Borsec). Universitatea Regele Ferdinand; Cluj Facultatea de Stiinte, 189 pp.

Principi, P., 1916. Le Dicotiledoni Fossili del Giacimento Oligocenico di Santa Giustina e Sassello in Liguria. Memorie alla descrizione della Carta Geologica d' Italia 6(1), 1-207.

Radon, M., Kvaček, Z., Walther, H., 2006. Oligocene plant megafossils and environment from the newly recovered locality of the Holý Kluk Hill near Proboštov (České Středohoří Mountains, Czech Republic). Acta Universitatis Carolinae, Geologica 47(1-4), 95-124.

Read, W.R., Hickey, L.J., 1972. A revised classification of fossil palm and palm-like leaves. Taxon 21(1), 129-137.

Reid, E.M., Chandler, E.M.J., 1926. The Bembridge Flora. Catalogue of Cainozoic plants in the department of geology, vol. 1. London: British Museum (Natural History).
Reid, E.M., Chandler, E.M.J., 1933. The London Clay Flora. Brit. Museum (Nat. Hist.), London, 206 pp.

Reuschel, Ch., Walther, H., 2006. Studien über oligozäne Populus-Arten aus der Weisselstersenke südlich von Leipzig, Sachsen (Deutschland). Feddes Repertorium 117(1-2), 1-33.

Rüffle, L., 1963. Die obermiozäne (sarmatische) Flora vom Randecker Maar. Paläontologische Abhandlungen 1, 139-298.

Sakala, J., 2000. Flora and vegetation of the roof of the main lignite seam in the Bílina mine (Most Basin, lower Miocene). Acta Musei Nationalis Pragae, B. Historia Naturalis 56(1-2), 49-84.

Saporta, G., 1862. Études sur la végétation du sud-est de la France a l'époque tertiaire. Annales des Sciences Naturelles Botanique, 4 séries 17, 191-311.

Saporta, G., 1867. Études sur la végétation du sud-est de la France a l'époque tertiaire. Annales des Sciences Naturelles Botanique, 5 séries 8, 5-136.

Saporta, G., 1889. Derniéres adjonctions a la flore fossile d' Aix-en-Provance. Annales des Sciences Naturelles Botanique, 7 séries, 10, 1-192.

Saporta, G., 1891. Recherches sur la végétationdu niveau aquitanien de Manosque. III. Amentacées, Salicinées et Urticinées. Mémoires de la Société géologique de France, Paléontologie, 9 (II), fasc. 1, 2, (III), fasc. 1, 2, 35-83.

Schimper, W.Ph., 1874. Traité de Paléontologie végétale. 3. J. B. Bailleire et fils, Libr. Acad. Médecine, Paris.

Sebe, K,. 2009. A Nyugat-Mecsek és környezete tektonikus geomorfológiai elemzése. Doktori értekezés, Pécsi Tudományegyetem, manuscript, $113 \mathrm{p}$ (in Hungarian).

Sebe, K., Magyar, I., Csillag, G., Sztanó, O., 2015a. Stratigraphy of Upper Miocene (Pannonian) sediments in the Mecsek region: new data, results and questions. In: Dályay, V., Sámson, M. (eds), Tisia Konferencia. Pécs, 2015. Február 27-28, 72-76; Pécs (Hungarian Geological Society) (in Hungarian with English abstract).

Sebe, K., Csillag, G., Dulai, A., Gasparik, M., Magyar, I., Selmeczi, I., Szabó, M., Sztanó, O., Szuromi-Korecz, A., 2015b. Neogene stratigraphy in the Mecsek region. In: Bartha, I., Kriván, Á., Magyar, I., Sebe K. (eds), Neogene of the Paratethyan Region. 6th Workshop on the Neogene of Central and South-Eastern Europe. An RCMNS Interim Colloquium. Programme, Abstracts, Field Trip Guidebook. 2015.05.31-06.03, Orfú, 102-124; Budapest (Hungarian Geological Society).

Sebe, K., Selmeczi, I., Szuromi-Korecz, A., Hably, L., Kovács, Á., Benkó Zs., 2019. Miocene syn-rift lacustrine sediments in the Mecsek Mts. (SW Hungary). Swiss Journal of Geosciences 112, 83-100.

Selmeczi, I., Hably, L., 2009. Oligocene Plant Remains from Oroszlány, Hungary. Neues Jahrbuch für Geologie und Paläontologie, Abh. Stuttgart 256(3), 353-361. 
Sitár, V., 1969. Die Paläoflora des Turiec-Beckens und ihre Beziehung zu den Mitteleuropäischen Floren. Acta geologica et Geographica Universitatis Comenianae, Geologica 17, 99-174.

Sitar, V., Kvaček, Z. Bůžek, Č., 1989. New late Neogene floras of southern Slovakia (Pinciná and Hajnačka). Zapadne Karpaty, ser. paleont. 13, 43-59. Bratislava.

Sitzenberger, E., 1851. Übersicht der Versteinerungen des grossherzogthums Baden. Diss. Freiburg.

Staub, M., 1882. Baranyamegyei mediterrán növények. (Mediterrean Plants from Com. Baranya). Magyar Királyi Földtani Intézet évkönyve 6(1), $23-42$.

Sternberg, K., v 1838. Versuch einer geognostischbotanischen Darstellung der Flora der Vorvelt, 7-8, Regensburg, Praha.

Strausz, L., 1926. A Mecsekhegység mediterrán rétegei. Matematikai és Természettudományi Értesító 42, 177-180. (in Hungarian).

Strausz, L., 1926-1928. Das Mediterran des Mecsekgebirges in Südungarn. Geologische und Palaeontologische Abhandlungen 15(5), 359-418.

Strausz, L., 1950. Őslénytani adatok Baranyából. Földtani Közlöny 53(7-9), 238-244. (in Hungarian).

Szafer, W., 1961. Mioceńska Flora ze Starych Gliwic na Śląsku (Miocene Flora of Stare Gliwice in Upper Silesia). Prace Instytutu Geologicznego 33, 1-205.

Szakmány, Gy., Józsa, S., 1994. Rare pebbles from the Miocene conglomerate of Mecsek Mts., Hungary. Acta Mineralogica-Petrographica, Szeged, $35,53-64$.

Unger, F., 1841-1847. Chloris protogaea, Leipzig, Engelmann, $150 \mathrm{pp}$.

Unger, F., 1845a. Chloris protogaea. H. 6-7, 25-90, Leipzig, Engelmann.

Unger, F., 1845b. Synopsis plantarum fossilium. Lipsiae, $330 \mathrm{pp}$.

Unger, F., 1850a. Genera et species plantarum fossilium. XL, 627 p., Wien (W. Braumüller).

Unger, F., 1850b. Die Gattung Glyptostrobus in der Tertiär Formations. Sitzber. B. Akad. Wiss. Mat.nat., Kl., 5, 434-435.

Unger, F., 1850c. Die fossile Flora von Sotzka. Denkschriften der Kaiserlichen Akademie der Wissenschaften / Mathematisch-Naturwissenschaftliche Classe 2, 3-67.

Unger, F., 1852. Iconographia plantarum fossilium. Denkschriften der Kaiserlichen Akademie der Wissenschaften, Mathematisch-Naturwissenschaftliche Classe 4, 73-118.

Unger, F., 1860. Sylloge Plantarum Fossilium I. Denkschriften der Kaiserlichen Akademie der Wissenschaften/Mathematisch-Naturwissenschaftliche Classe 19, 1-48.

Unger, F., 1864. Sylloge Plantarum Fossilium II. Denkschriften der Kaiserlichen Akademie der Wissenschaften, Mathematisch-Naturwissenschaftliche Classe 22, 1-36.
Unger, F., 1866. Sylloge Plantarum Fossilium III. Denkschriften der Kaiserlichen Akademie der Wissenschaften, Mathematisch-Naturwissenschaftliche Classe 25, 1-76.

Unger, F., 1867. Die fossile Flora von Kumi. Denkschriften der Kaiserlichen Akademie der Wissenschaften, Mathematisch-Naturwissenschaftliche Classe 27, 27-87.

Velenovský, J., 1881. Die Flora aus den ausgebrannten tertiären Letten von Vršovic bei Laun. Abhandlungen der Böhmischen Gesellschaft der Wissenschaften $6,11,3-56$.

Velitzelos, E., Kvaček, Z., Denk, T., Velitzelos, D., 2002. Field trip Guidebook Evia Island Neogene Sedimentary Basin of Kymi/Aliveri. 6th European Paleobotany-Palynology Conference. Athens, Greece. University of Athens, Greece, $61 \mathrm{pp}$.

Walther, H., 1999. Die Tertiärflora von Kleinsaubernitz bei Bautzen. Palaeontographica, Abt. B 249(1-6), 63-174.

Walther, H., Zastawniak, E., 1991. Fagaceae from Sośnica and Malczyce (near Wrocław, Poland). A revision of original materials by Göppert 1852 and 1855 and a study of new collections. Acta Palaeobotanica $31,153-199$.

Weber, O., 1852. Die Tertiärflora der niederrheinischen Braunkohlenformation. Palaeontographica, Abt. B 2, 117-285.

Wessel, Ph., Weber, C.O., 1856. Neuer Beitrag zur Tertiärflorader niederrheinischen Braunkohlenformation. Palaeontographica 4, 1-57.

Weyland, H., 1938. Beiträge zur Kenntnis der rheinischen Tertiärflora. II. Erste Ergänzungen und Berichtungen zur Flora der Blätterkohle und des Polierschiefers von Rott im Siebengebirge. Palaeontographica, Abt. B 83, 67-122.

Weyland, H., 1943. Beiträge zur Kenntnis der niederrheinischen Tertiärflora. VI. Vierte Ergänzung und Berichtigung zur Flora der Blätterkohle und des Polierschiefers von Rott im Siebengebirge. Palaeontographica Abt. B 93, 93-136.

Weyland, H., 1948 Beiträge zur Kenntnis der Rheinischen Tertiärflora. VII. Fünfte Erganzungen und Berichtigungen usw. Palaeontographica, Abt. B 88, 113-188.

Worobiec, G., Worobiec, E., Szynkiewicz, A., 2012. Plant assemblage from the Upper Miocene deposits of the Bełchatów Lignite Mine (Central Poland). Acta Palaeobotanica 52(2), 369-413.

Zastawniak, E., 1972. Pliocene leaf flora from Domanski Wierch near Czarny Dunajec (Western Carpathians, Poland). Acta Paleobotanica 13, 1-73.

Zastawniak, E., 1980. Sarmatian leaf flora from the southern margin of the Holy Cross Mts. (South Poland). Praze Muzeum Ziemi 33, 39-108.

Zidianakis, G., Iliopoulos, G., Zelilidis, A., KovarEder, J., 2015. Myrica from the plant assemblage 1 of Pitsidia (Crete, Late Miocene): putting the puzzle together. Palaeontographica, Abt. B 293(1-6), 149-171. 